\begin{tabular}{|c|c|c|}
\hline Beitr. Ent. & Keltern & ISSN 0005-805X \\
\hline $59(2009) 1$ & S. 33 -101 & 15.07 .2009 \\
\hline
\end{tabular}

\title{
On the taxonomy and zoogeography of some Palaearctic Aleochara species of the subgenera Xenochara MuLSANT \& REY and Rheochara MulsANT \& REY
}

\section{(Coleoptera: Staphylinidae: Aleocharinae)}

With 228 figures and 6 maps

VOLKer Assing

\section{Summary}

Based on a study of types and additional material of Palaearctic Aleochara species currently attributed to the subgenera Xenochara Mulsant \& Rey, 1874 and Rheochara Mulsant \& Rey, 1875, four species groups are established: the A. cuniculorum group, the A.parvicornis group, the A.laevigata group, and the $A$. maculata group. Twenty-five species are (re-)described and illustrated, ten of them new to science: Aleochara (Xenochara) gontarenkoi sp. n. (Ukraine, Turkey) and A. (X.) utriculata sp. n. (Mongolia) of the A. cuniculorum group; $A$. (X.) suslica sp. n. (Ukraine) of the A. parvicornis group; $A$. (X.) grandeguttata sp. $\mathrm{n}$. (Turkey, Armenia, Hungary), A. (X.) brevilaminata sp. n. (Middle Asia), and $A$. (X.) falcata sp. n. (Russia) of the A. laevigata group; $A$. (X.) cristata sp. n. (Western Mediterranean) and $A$. (X.) hamulata sp. n. (Eastern Mediterranean) of the $A$. maculata group; $A$. (X.) himalayanae sp. n. (China: Gansu, Qinghai) and $A$. (X.) digitulata sp. n. (China: Gansu) of the $A$. sparsa group. The external and sexual characters of several additional species are illustrated. The following synonymies are proposed: Xenochara Mulsant \& ReY, $1874=$ Dyschara Mulsant \& Rey, 1874, syn. n., = Ophiochara Bernhauer, 1901, syn. n., = Euryodma Reitter, 1909, syn. n.; Aleochara cuniculorum KraAtz, 1858 = A. peusi WAgner, 1949, syn. n.; A. parvicornis FauveL, $1900=$ A. bobaci KrásA, 1933, syn. n., = A. gracilis LiKovskŕ, 1965, syn. n., preoccupied. Three names are revalidated: A. dalila Likovskŕ, 1984 (previously a synonym of $A$. peusi); A. lonae Grideldi, 1924 (previously a synonym of $A$. laevigata Gyllenhal, 1810); $A$. accepta Likovskŕ, 1972 (previously a synonym of A. signata (SAHLberG, 1876)). Lectotypes are designated for A. cuniculorum KraAtz, 1858, A. breiti Ganglbauer, 1897, A. bisignata Erichson, 1837, A. cornuta Fauvel, 1886, A. peeziana Lohse, 1961, A. tenuicornis KraATZ, 1856, and A. pernigra SCHUbert, 1906. Additional records of Aleochara species are reported from the Palaearctic region, among them numerous new country records. The distributions of fourteen species are mapped.

\section{Key words}

Coleoptera, Staphylinidae, Aleocharinae, Aleochara, Xenochara, Rheochara, Palaearctic region, taxonomy, new species, new synonymies, revalidations, lectotype designations, distribution, ecology.

\section{New species}

Aleochara (Xenochara) gontarenkoi sp. n., A. (X.) utriculata sp. n., A. (X.) suslica sp. n., A. (X.) grandeguttata sp. n., A. (X.) brevilaminata sp. n., A. (X.) falcata sp. n., A. (X.) cristata sp. n., A. (X.) hamulata sp. n., $A .(X$. himalayanae sp. n., $A$. (X.) digitulata sp. n. 


\section{Zusammenfassung}

Nach Untersuchung von Typen und weiterem Material paläarktischer Aleochara-Arten der Untergattungen Xenochara Mulsant \& Rey, 1874 und Rheochara Mulsant \& Rey, 1875 werden vier Artengruppen charakterisiert: die A.cuniculorum-Gruppe, die A.parvicornis-Gruppe, die A. laevigata-Gruppe und die A. maculata-Gruppe. 25 Arten werden beschrieben bzw. redeskribiert und abgebildet, darunter zehn neue Arten: Aleochara (Xenochara) gontarenkoi sp. n. (Ukraine, Türkei) und $A$. (X.) utriculata sp. n. (Mongolei) aus $\operatorname{der}$ A. cuniculorum-Gruppe; $A$. (X.) suslica sp. n. (Ukraine) aus $\operatorname{der} A$. parvicornis-Gruppe; $A$. (X.) grandeguttata sp. n. (Türkei, Armenien, Ungarn), A. (X.) brevilaminata sp. n. (Mittelasien) und $A$. (X.) falcata sp. n. (Russland) aus der A. laevigata-Gruppe; $A$. (X.) cristata sp. n. (westliches Mittelmeergebiet) und A. (X.) hamulata sp. n. (östliches Mittelmeergebiet) aus $\operatorname{der} A$. maculata-Gruppe; $A$. (X.) himalayanae sp. $\mathrm{n}$. (China: Gansu, Qinghai) und $A$. (X.) digitulata sp. n. (China: Gansu) aus der A. sparsa-Gruppe. Die äußeren Merkmale und Genitalien einiger weiterer Arten werden abgebildet. Folgende Synonymisierungen werden vorgenommen: Xenochara Mulsant \& Rey, 1874 = Dyschara Mulsant \& Rey, 1874, syn. n., = Ophiochara Bernhauer, 1901, syn. n., = Euryodma Reitter, 1909, syn. n.; Aleochara cuniculorum KraAtz, $1858=$ A. peusi Wagner, 1949, syn. n.; A. parvicornis Fauvel, $1900=$ A. bobaci Krása, 1933, syn. n., = A. gracilis Lıkovsкú, 1965, syn. n.; A. gracilis LıкovskÝ ist darüber hinaus ein primäres Homonym. Drei Namen werden revalidiert: A. dalila Likovskŕ, 1984 (bisher ein Synonym von A. peusi); A. lonae Gridelli, 1924 (bisher ein Synonym von A. laevigata Gyllenhal, 1810); A. accepta Likovskŕ, 1972 (bisher ein Synonym von A. signata (Sahlberg, 1876)). Für A. cuniculorum Krattz, 1858, A. breiti Ganglbauer, 1897, A. bisignata Erichson, 1837, A. cornuta Fauvel, 1886, A. peeziana Lohse, 1961, A. tenuicornis KraAtz, 1856 und $A$. pernigra Schubert, 1906 werden Lectotypen designiert. Weitere Nachweise verschiedener Aleochara-Arten werden aus der paläarktischen Region gemeldet, darunter zahlreiche Erstnachweise. Die Verbreitungsgebiete von 14 Arten werden anhand von Karten illustriert.

\section{Introduction}

According to the Palaearctic catalogue (SMEtana 2004) and including subsequently published species descriptions and synonymies, the speciose genus Aleochara GravenHorst, 1802 is currently represented in the Palaearctic region by more than 220 species (six nomina dubia not included) in 16 subgenera. Many of them have not been treated in the context of modern revisions, and their phylogenetic affiliations and sexual characters are unknown.

The first - and only - comprehensive study of Palaearctic Aleochara was provided by BernHaUer (1901), who presented a key to species and descriptions - exclusively based on external characters - of the 79 Palaearctic taxa known at that time. Subsequently, numerous species were described by various authors, particularly by LiкоvsкÝ (e. g., 1965a, 1965b, 1968, 1971, 1972, 1973, 1981), who - at least in some cases - gave rough sketches of the genitalia. However, since these illustrations are mostly inadequate for a reliable interpretation and, furthermore, since many species have not been illustrated at all, a reliable identification of a large number of species based on the descriptions and keys available in the literature is virtually impossible. This particularly applies to the subgenus Xenochara Mulsant \& Rey, 1874, which alone currently includes as many as 92 species in the Palaearctic region. Modern comprehensive studies including detailed illustrations of sexual characters exist only for some subgenera, e. g., Coprochara Mulsant \& Rey, 1874 by Maus (1998, 1999), Emplenota Casey, 1884, Polystomota Casey, 1906, and Triochara Bernhauer, 1901 by Assing (1995), as well as for some regions, e. g., Britain (Welch 1997) and Turkey (Assing 2007a).

The vast majority of Aleochara species are larval parasitoids of cyclorrhapheous Diptera; for a synopsis of the current knowledge of dipteran hosts see Maus et al. (1998). At present, the only representative of the genus known to have a (primitive) non-parasitoid lify cycle is A. clavicornis Redtenbacher, 1849, the type species of Heterochara Mulsant \& Rey, 1874 (Maus et al. 1998). 
However, the ecology (e. g., myrmecophily) and the relatively constant body size of other representatives of this subgenus suggests that the same may be true of all Heterochara species. In addition to the difficulties posed by the taxonomic history of the genus as outlined above, taxonomic studies on Aleochara are further complicated by the parasitoid life history and its effects on morphology and zoogeography. Firstly, parasitoid Aleochara species are usually subject to extreme intraspecific variation in body size (depending on the size of the parasitised dipteran pupa), proportions, and even the size of the aedeagus, so that a representative assessment of taxonomically significant external characters is often possible only based on a study of a larger sample of specimens. Secondly, cyclorrhapheous Diptera are particularly abundant in ephemeral - and often more or less randomly distributed - habitats such as carrion, excrements, mushrooms, rotting plant material, and nests. This explains why the vast majority of Aleochara species actively disperse by flight and, in consequence, are generally very widespread. Numerous species recorded from the Palaearctic region have a trans-Palaearctic, a Holarctic, or even a Cosmopolitan distribution. For the taxonomist, this means that species described from very distant localities have to be considered when trying to assess the specific identity of material. Among the Aleochara species of the Palaearctic region, restricted distributions have been shown almost exclusively for some species evidently adapted to high-altitude or other very specialised habitats such as subterranean nests, as well as for most species of the subgenus Ceranota CASEY, 1906, whose life history is largely unknown.

The present study was originally meant to focus on the taxonomic status of some Western Palaearctic nidicolous Xenochara species. However, it soon became clear that, owing to considerable taxonomic confusion in this subgenus and the typological and weakly defined subgeneric concept, the scope of the project had to be broadened and species previously attributed to other species groups or even other subgenera had to be considered. Nevertheless, four species groups required and received special attention, all of them currently in Xenochara: the A. cuniculorum group, the $A$. parvicornis group, the $A$. laevigata group, and the $A$. maculata group. In addition, taxonomic notes based on type studies, as well as zoogeographic data on miscellaneous other species of the subgenera Xenochara and Rheochara Mulsant \& ReY, 1875 are presented.

\section{Material and methods}

The material referred to in this study is deposited in the following public and private collections:

$\begin{array}{ll}\text { HNHM } & \text { Hungarian Natural History Museum, Budapest (Gy. Makranczy, O. Merkl) } \\ \text { IRSNB } & \text { Institut royal des Sciences naturelles de Belgique, Bruxelles (Y. Gérard) } \\ \text { MCSNT } & \text { Museo Civico di Storia Naturale, Trieste (A. Colla) } \\ \text { MHNG } & \text { Muséum d'Histoire Naturelle Genève (G. Cuccodoro) } \\ \text { MNHUB } & \text { Museum für Naturkunde der Humboldt-Universität Berlin (J. Frisch) } \\ \text { NHMW } & \text { Naturhistorisches Museum Wien (H. Schillhammer) } \\ \text { SDEI } & \text { Senckenberg Deutsches Entomologisches Institut, Müncheberg (L. Behne, L. Zerche) } \\ \text { TAU } & \text { National Museum of Natural History, Tel Aviv University (A. Freidberg, via B. Feldmann) } \\ \text { WMN } & \text { Westfälisches Museum für Naturkunde, Münster (H. Terlutter) } \\ \text { cAss } & \text { author's private collection } \\ \text { cFel } & \text { private collection B. Feldmann, Münster } \\ \text { cGom } & \text { private collection N. Gompel, Marseille } \\ \text { cGon } & \text { private collection A. Gontarenko, Odessa } \\ \text { cSch } & \text { private collection M. Schülke, Berlin } \\ \text { cWun } & \text { private collection P. Wunderle, Mönchengladbach }\end{array}$


The morphological studies were conducted using a Stemi SV 11 microscope (Zeiss Germany) and a Jenalab compound microscope (Carl Zeiss Jena). For the photographs a digital camera (Nikon Coolpix 995) was used.

Head length was measured from the anterior margin of the clypeus to the posterior suture of the head; elytral length from the apex of the scutellum to the posterior margin of the elytra; the length of the median lobe of the aedeagus from the apex of the ventral process to the base of the capsule. In accordance with the latest findings (DeMarzo, unpublished), the thin sclerotised proximal portion of the spermatheca is referred to as the proximal part of the spermathecal capsule (previously usually referred to as the spermathecal duct); the term spermathecal duct is restricted to the proximal unsclerotised (membraneous) portion of the spermatheca.

The maps were generated using the online generic mapping tool (GMT) of the Geomar website at www.aquarius.ifm-geomar.de/omc.

\section{Results}

\section{On the subgenus Xenochara Mulsant \& ReY, 1874}

Xenochara Mulsant \& Rey, 1874: 60; type species: Aleochara decorata Aubé 1850 (= Aleochara puberula KLUG 1832)

Homoeochara Mulsant \& Rey, 1874: 130 (type species: Aleochara sparsa Heer, 1839).

Polychara Mulsant \& Rey, 1874: 64 (type species: Aleochara discipennis Mulsant \& Rey, 1853).

Dyschara Mulsant \& Rey, 1874: 141 (type species: Aleochara inconspicua Aubé, 1850); syn. n.

Isochara Bernhauer, 1901: 440 (type species: Aleochara tristis GravenHorst, 1806).

Ophiochara Bernhauer, 1901: 483 (type species: Aleochara breiti Ganglbauer, 1897); syn. n.

Euryodma Reitter, 1909: 23 f. (type species: Aleochara brevipennis Gravenhorst, 1806); syn. $\mathbf{n}$.

\section{Comment:}

According to the Palaearctic catalogue (Smetana 2004) and including subsequent additions, the speciose subgenus Xenochara was previously represented in the Palaearctic region by 92 species. Three former subgenera - Homoeochara, Polychara, and Isochara - had already been synonymised with Xenochara (KLIMASZEwski 1984; SMETANA 2004).

Dyschara and Ophiochara are distinguished from other subgenera primarily by (aut-)apomophies, the former by a sexual dimorphism of antennomere XI and the latter by the strongly bulging eyes. The type species of Ophiochara, A. breiti, was originally described in the subgenus Polychara, now a synonym of Xenochara, and subsequently moved to the subgenus Ophiochara, of which it is the type species, by Bernhauer (1901). An examination of material of $A$. breiti revealed high similarities and synapomorphies shared with $A$. cuniculorum and other nidicolous species currently attributed to the subgenus Xenochara, but yielded no characters suggesting that it should not be a member of the A. cuniculorum group (see below). The original description of Ophiochara is exclusively based on the shape of the head, which results from the conspicuously large and bulging eyes. The enlarged eyes are undoubtedly an adaptation to the habitat of this and related species and they represent no convincing evidence that $A$. breiti should not refer to Xenochara.

Ophiochara was already synonymised with Polychara by Wagner (1949), but this synonymy was either overlooked or not accepted by subsequent authors.

Similarly, the type species of Dyschara, A. inconspicua, may be characterised by a conspicuous sexual dimorphism of antennomere XI, but this in itself does not constitute a plausible argument 
that this species should represent a distinct subgenus. On the contrary, neither the sexual characters nor other external features present any evidence that $A$. inconspicua should not be a close relative of species currently attributed to Xenochara, and there are numerous other examples of sexual dimorphisms of various body parts in the genus.

In the key and the description provided by ReItTer (1909), Euryodma is distinguished from Xenochara and other subgenera primarily by characters such as the density of the punctation of the forebody, the coarseness of the punctation of the abdomen, and the pubescence or the elytra.

However, these are variable characters in Xenochara - sometimes even intraspecifically - and do not constitute sufficient evidence that the type species A. brevipennis should not be a member of Xenochara. In the course of the present study, it was found that the external characters (punctation of forebody and abdomen, body shape), the secondary sexual characters (shape and chaetotaxy of tergite and sternite VIII), as well as the morphology of the primary sexual characters (shape and internal structures of the median lobe of the aedeagus; spermatheca with long proximal portion of the duct) suggest a close relationship of $A$. brevipennis to A. haematoptera and A. tenuicornis, which are currently attributed to Xenochara.

In conclusion, Xenochara, Dyschara, Ophiochara, and Euryodma are here considered synonyms. Xenochara and Dyschara are the oldest names and described in the same work. Since the former has been - by far - the more speciose and better known taxon, it is here designated as the senior name.

\section{The species of the Aleochara cuniculorum group}

As far as is currently known, all the species of the $A$. cuniculorum group are nidicolous. They are characterised as follows: body of moderate size and dark brown to blackish, the elytra posteriorly usually with a more or less extensive yellowish or reddish spot; eyes large, at least as long - usually longer than - postocular region in dorsal view, often strongly convex and distinctly projecting from lateral contours of head; legs long and slender, metatarsus approximately as long as metatibia; abdomen, including the anterior impressions of tergites III-V, rather densely punctate; male sternites VI and VII usually with rather long and posteriorly dense pubescence; male sternite VIII distinctly produced posteriorly; aedeagus with small median lobe (in relation to body size); median lobe more or less arched (lateral view); flagellum in internal sac of characteristic morphology, short, stout, and subdivided into two parts; apical sclerotised internal structures of characteristic shape; female sternite VIII with convex posterior margin; spermatheca of rather uniform morphology.

From the often similar species of the $A$. laevigata group, the members of the $A$. cuniculorum group are distinguished particularly by the modified pubescence of the male sternites VI-VII (A. laevigata group: unmodified), the posteriorly distinctly produced male sternite VIII (A. laevigata group: weakly produced and obtusely angled), the relatively smaller aedeagus, the morphology of the flagellum in the internal sac of the aedeagus (A. laevigata group: long and slender, not subdivided into two parts), the different shape of the apical sclerotised internal structures, and by the different general morphology of the spermatheca.

Six species are currently recognised in this group: A. cuniculorum, A. dalila, A. breiti, A. gontarenkoi, A. longipes, and $A$. utriculata. 
Assing, V.: Palaearctic Aleochara species of the subgenera Xenochara Mulsant \& Rey

\section{Aleochara (Xenochara) cuniculorum KRAATZ, 1858 (Figs 1-28, Map 1)}

Aleochara cuniculorum KraATZ, 1858: clxxxviii f. Aleochara (Polychara) peusi WaGner, 1949: 18 ff.; syn. n.

\section{Type material examined:}

A. cuniculorum: Lectotype $0^{\star}$, present designation: "Marly, Lapin / 452 / Bonvl / Gallia / cuniculorum / B. / coll. Heyden / Coll. DEI Eberswalde / Aleochara cuniculorum Kraatz / Lectotypus des. Lohse 1986 / coll. DEI Müncheberg / Lectotypus ơ Aleochara cuniculorum Kraatz desig. V. Assing 2009 / Aleochara cuniculorum Kraatz, det. V. Assing 2009" (SDEI). Paralectotype + : same data as lectotype (SDEI).

A. peusi: Paratype + : "Mark: Umg. Schönefeld / Paratypus / Aleochara Peusi m. det. H. Wagner, Paratype! / Coll. W. Liebmann, Arnstadt / Coll. DEI Eberswalde / peusi Wgn. det. Dr. G. A. Lohse 197 [sic] / coll. DEI Müncheberg / Aleochara cuniculorum Kraatz, det. V. Assing 2008" (SDEI).

Additional material examined:

Tunisia: 1 옹, Sousse, $12 \mathrm{~km}$ NW Sousse, El Kantaouri, 25.-30.XI.1992, leg. Wrase (cAss).

Algeria: $1 \sigma^{*}, 2$ exs., Oran, leg. Reitter, etc. (SDEI, cAss); 3 exs., "Algier", leg. Reitter (NHMW).

Morocco: 3 exs., locality not specified, leg. Fauvel, Quedenfeldt (NHMW).

France: 1 ex., Pyrénées-Orientales, locality not specified (NHMW); 1 ex., Provence, locality not specified (SDEI); 1 ex., Basses-Normandie, Calvados, Forêt de Cinglais, leg. Dubourgais (NHMW); 2 exs., Calvados, leg. Dubourgais (NHMW).

Germany: Nordrhein-Westfalen: $20^{\star} \sigma^{\star}$, Porta Westfalica, Wittekindsberg, badger burrows, 2.VIII.1992, leg. Borcherding (cAss); $1 \delta^{\star}, 1$, same data, but 16.IX.1985 (cWun); 1 , Mönchengladbach-Gerkerath, moist mixed oak and alder forest, 22.XI.1998, leg. Wunderle (cWun). Niedersachsen: 1 क , Göttingen, Westerberg, badger burrows, 1.VI.1992, leg. Borcherding (cAss); $1 \sigma^{\star}$, E Hannover, Immensen, field, pitfall, II.1989 (cAss); 1 o $^{\star}$, Lüneburger Heide, Schneverdingen, Calluna heathland, scarcely vegetated sandy spot, pitfall, V.1995 (cAss); 1 \% , same data, but IV.1996 (cAss); 1 o, 1 ex., same data, but III.1997 (cAss, cSch); $1 \sigma^{7}$, Schneverdingen, Calluna heathland, pitfall, VI.2000 (cAss); 1 ㅇ, same data, but IV.2000 (cAss); 2 exs., Helmstedt env. (NHMW); 9 exs., Borkum, rabbit burrows, 22.V.1937, leg. Struve (NHMW, cAss). Hessen: 3 우 옹 Pohlheim Holzheim, hamster burrows, VI.1986, leg. Wunderle (cWun). Schleswig-Holstein: 1 ex., Husum, leg. v. Varendorff(NHMW). Mecklenburg-Vorpommern: 1 on $^{\star}$, Rerik i. M., 31.VII.1947 (SDEI); 1 \% [det. Feldmann], Rüterberg/Elbe, car-net, 3.V.2006, leg. Köhler (cFel); 1 ex., "Strelitz" (NHMW). SachsenAnhalt: 3 exs., Köthen, 5.IX.1909, leg. Heidenreich (SDEI, cAss); 13 exs., Köthen, leg. Heidenreich, etc. (SDEI); 1 ex., Köthen, 14.VII.1901 (NHMW); 4 exs., Dessau, badger burrows, XII.1937, leg. Heidenreich (SDEI); 2 exs., same data, but XII.1938 (NHMW, cAss); 4 exs., Dessau (NHMW). Berlin/Brandenburg: 1 ex., Schildow (SDEI); 4 exs., Berlin, leg. Eppelsheim, Krieger, Weise, etc. (NHMW). Thüringen: 1 ex., Gotha (SDEI); 1 ๙ $^{\star}$, Gotha, Xangenhan (SDEI); 1 o, Kyffhäuser, Schlachtberg, 9.V.1989, leg. Peschel (cAss); 1 ㅇ, Nordhausen, hamster burrows, 12.VIII.1913, leg. Petry (SDEI); 2 exs., locality not specified (NHMW, SDEI). Sachsen: 3 exs., Taucha, hamster burrows, 18.IX.1904, leg. Linke (NHMW); $20^{\star} \sigma^{\star}, 1$ \% , Leipzig, leg. Linke (NHMW). Locality not specified: $1 \sigma^{\circ}$, "Mittl. Elbe", leg. Heidenreich (NHMW).

Italy: 1 \% , Toscana, Monte Pisani, leg. Linke (NHMW).

Austria: Niederösterreich/Wien: $1 \mathrm{o}^{\mathbf{A}}, 2$ 우, Haschendorf near Wiener Neustadt, pitfall, IV.1968, leg. Malicky (cAss); 1 ex., Brucker Heide, leg. Scheerpeltz (NHMW); 2 exs., Wien env., leg. Breit (NHMW);

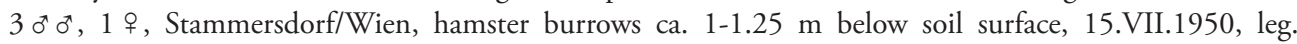
Schweiger (NHMW, cAss); 2 exs., Rodaun, leg. Lang (NHMW).

Czech Republic: $10^{\star}$, Velká Chuchle, hamster burrows, leg. Machulka (cAss); $30^{\star} 0^{\star}, 2$ ㅇ ㅇ, 2 exs., Závist, leg. Zeman (NHMW, cAss).

Slovakia: 1 ex., Bratislava, leg. Zoufal (NHMW).

Poland: 1 ex., "Herrnstadt" (SDEI); 3 우, "Pommern", leg. Schmidt (NHMW). 
Romania: 1 ex., 12 km from Piatra Neamț, Monastir Horaica (NHMW).

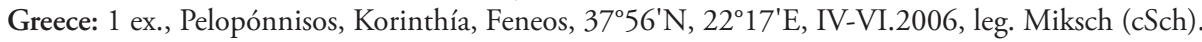

Turkey: Konya: $10^{\star}$, Seydişehir env., 1400 m, 5.-6.VI.2003, leg. Smatana (cAss). Aksaray: $2 o^{\star} o^{\star}, 5$ exs., "Niğde" [probably incorrect; the locality is apparently in Aksaray], Taşpinar, Spermophilus burrows, 10.IV.1966 (NHMW, cAss). Urfa: 1 o , 1 ㅇ, Urfa, 600 m, V.1976, leg. Schubert (NHMW, cAss).

Georgia: 1 + , Likhskiy Khrebet ["Suramgeb."], "Michailowo", leg. Leder (NHMW).

Russia: $1 \sigma^{\star}$, Sarepta, leg. Kraatz (NHMW).

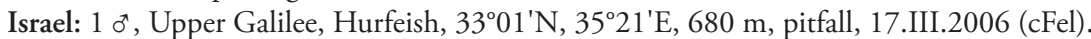

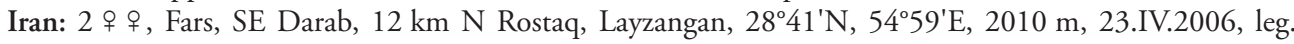
Frisch \& Serri (MNHUB, cAss).

Brazil: $1 \sigma^{\star}$, Santa Catharina, Rio Capivary, 1888, leg. Fruhstorfer (SDEI).

Locality not specified, illegible, or not identified: 7 exs. (NHMW, SDEI); 1 ex., "Jebel Hadir [?]", leg. Quedenfeldt (NHMW); 1 ex., "Silesia" (NHMW).

\section{Comment:}

The original description of $A$. cuniculorum is based on an unspecified number of syntypes collected "près de Paris par MM. Jaquelin du Val et Henry de Bonvouloir, dans les trous le lapins" (KraAtZ 1858). Two specimens qualifying as types, a male and a female, were found at the SDEI. The male is designated as the lectotype. One of the labels attached to this specimen suggests that G. A. Lohse intended to designate it as the lectotype, but this designation was never published.

Aleochara peusi was described from several specimens ("in geringer Anzahl") from the "TeltowPlateau bei Schönefeld", two specimens from "Köthen (Anhalt)", "zahlreiche Stücke" from "Dessau (XII.37) in einem Dachsbau", and two specimens from "Thale im Harz" (WAGNer 1949). According to the key provided with the original description of $A$. peusi, this species is distinguished from $A$. cuniculorum by the shorter antennae with more transverse antennomeres V-VII, the more convex eyes, the denser and coarser punctation of the abdominal tergites VI and VII, and by the slightly shorter legs with relatively shorter mesotarsi. However, an examination of a paratype and additional specimens previously identified as $A$. peusi, some of them from Köthen and Dessau, revealed that, regarding these characters, the material is within the range of intraspecific variation of the variable A. cuniculorum (Figs 3-4). Also, the genitalia are identical (Figs 11$12,13-28$ ), so that $A$. peusi is placed in synonymy with the senior name $A$. cuniculorum.

Aleochara dalila LikovsкÝ, 1984, previously a subjective junior synonym of $A$. peusi, is revalidated (see the following section).

\section{Redescription:}

Body length: 3.4-6.2 mm. Habitus as in Fig. 1. Coloration: head, pronotum, and abdomen blackish; elytral disc blackish, posteriorly with moderately delimited reddish spot of very variable size; this spot is usually rather small and of triangular shape, but may occasionally be almost completely obsolete or very large, leaving only the anterior margin, the scutellar region, and the lateral margins blackish; legs dark brown, with the tarsi and often also the tibia reddish to reddishbrown; antennae blackish-brown.

Head weakly oblong to weakly transverse; punctation fine and sparse; interstices much wider than diameter of macropunctures, without microsculpture; eyes variable, 1.8-2.5 times as long as postocular region in dorsal view, and moderately to distinctly convex (Fig. 2). Antenna rather short and slender, but variable (Figs 3-4).

Pronotum 1.28-1.39 times as wide as long and 1.50-1.64 times as wide as head, widest in or slightly behind the middle; posterior angles weakly marked; punctation slightly more distinct, more defined, and denser than that of head; interstices distinctly wider than diameter of punctures and without microsculpture (Fig. 2). 


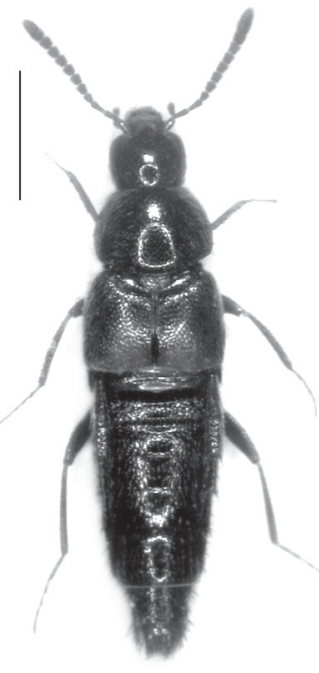

1

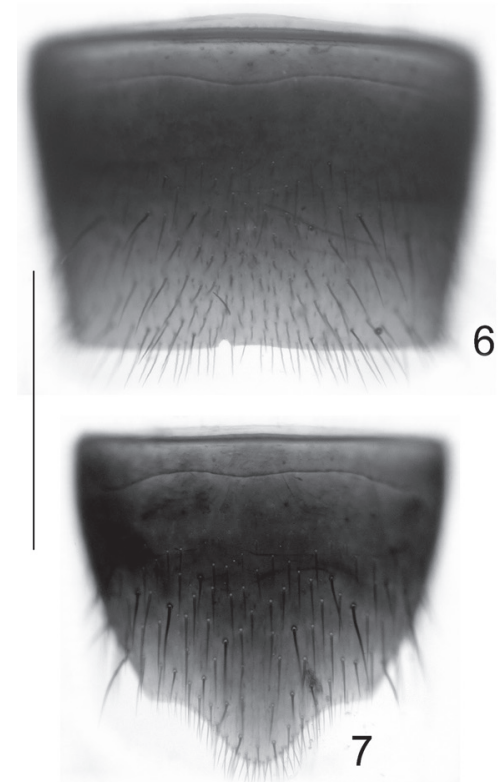

Figs 1-12: Aleochara cuniculorum KraAtz: habitus (1); forebody (2); antennae of specimens from Turkey (3) and Köthen, Germany (4); abdomen (5); male sternite VII (6); male sternite VIII (7); apical portion of paramere (8); apical internal structures of aedeagus of lectotype (9); posterior portion of female sternite VIII (10); spermatheca (11-12). Scale bars: 1: $1.0 \mathrm{~mm}$; 2-7, 10: 0.5 mm; 8-9, 11-12: $0.1 \mathrm{~mm}$.

Elytra approximately 0.8 times as long as pronotum; posterior margin near posterior angles obliquely truncate, not sinuate; punctation distinctly coarser and denser than that of pronotum (Fig. 2); interstices narrower than diameter of punctures. Legs long and slender, but length somewhat variable; metatarsus approximately as long as metatibia; metatarsomere I slightly to distinctly longer than the combined length of II and III, sometimes almost as long as the combined length of II-IV. 


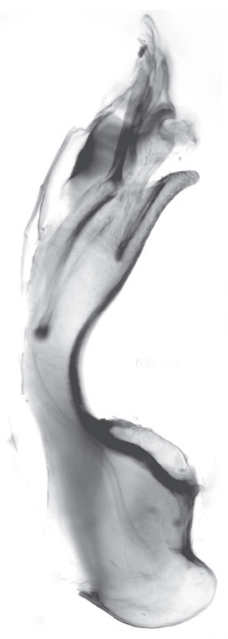

13

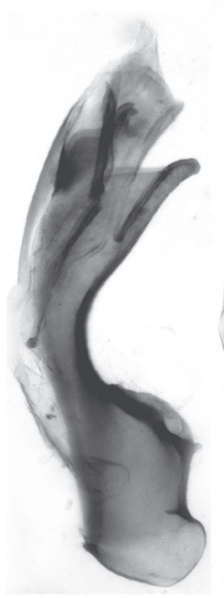

19

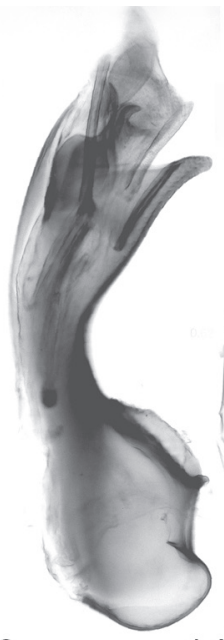

14

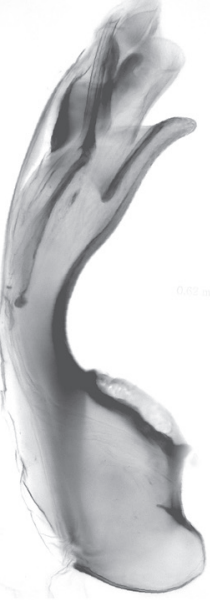

20

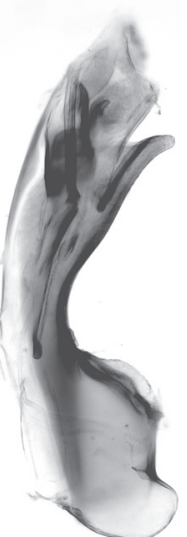

15

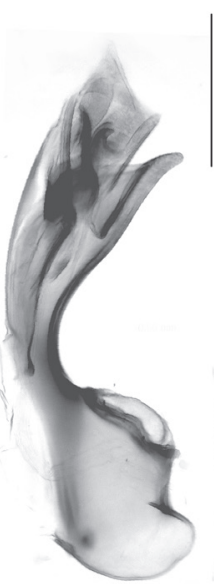

21

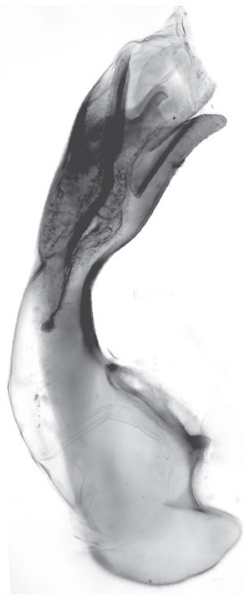

16

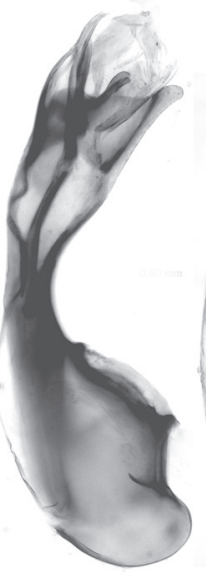

17

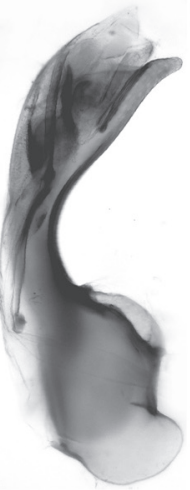

18

Figs 13-24: Aleochara cuniculorum KraAtz: median lobe of aedeagus in lateral view of lectotype (13) and males from Niederösterreich (14), Czech Republic (15), Germany (16-20), Turkey (21-23), and Russia (24). Scale bar: $0.2 \mathrm{~mm}$.

Abdomen: tergites III-V with moderately deep anterior impressions, the impression on tergite $\mathrm{V}$ usually distinctly shallower than those on tergites III and IV; tergite VI without anterior impression; punctation of anterior impressions of tergites III-V dense and moderately coarse, that of remaining tergal surfaces somewhat variable, sparser on posterior than on anterior tergites; tergites III-VII without distinct microsculpture (Fig. 5); posterior margin of tergite VIIÍ weakly concave. $\sigma^{*}$ : pubescence of sternite VII not conspicuously dense near posterior margin (Fig. 6); posterior margin of sternite VIII distinctly produced in the middle (Fig. 7); median lobe of aedeagus approximately $0.6 \mathrm{~mm}$ long, with slender and rather long ventral process (Figs 13-24); flagellum rather stout and short, apical internal structures shaped like a wrench (Figs 9, 25-28); apical lobe of paramere as in Fig. 8.

+ : posterior margin of sternite VIII broadly convex (Fig. 10); spermatheca as in Figs 11-12. 


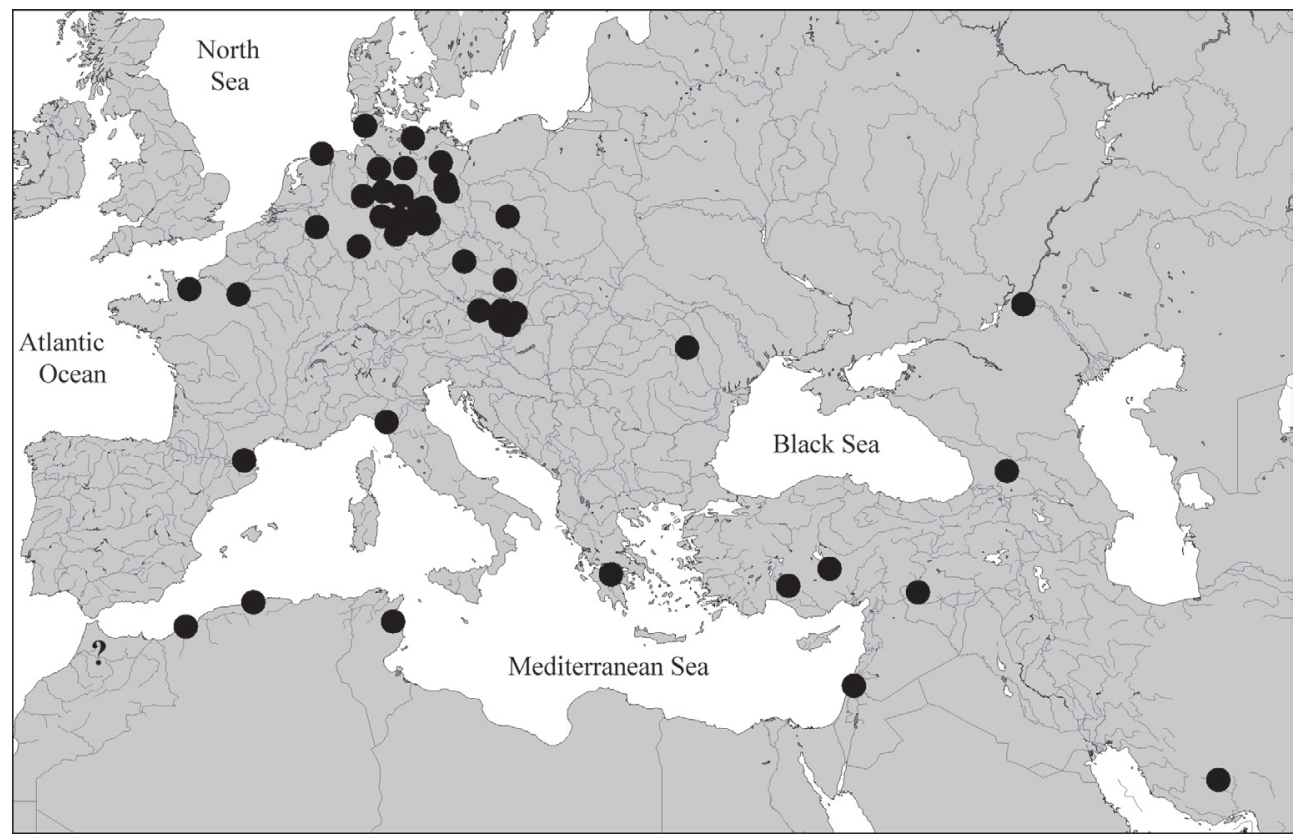

Map 1: Distribution of Aleochara cuniculorum KraAtz in the Western Palaearctic region, based on revised records. ?: record from Morocco without specified locality.

\section{Comparative notes:}

Based on external characters (large eyes, long legs, coloration, punctation, etc.) and particularly the similar male primary and secondary sexual characters, as well as the similar habitat, A. cuniculorum is very closely related to A. breiti. It is distinguished from this species by slightly smaller average size, the narrower (in relation to pronotum) and more slender head, the slightly smaller and less bulging eyes, the more convex pronotum, the more slender apex of the ventral process of the median lobe of the aedeagus (lateral view), as well as by the different shape of the apical internal structures of the aedeagus (see Figs 25-32).

\section{Distribution and bionomics:}

According to Smetana (2004), the distribution of $A$. cuniculorum (including $A$. peusi) ranges from North Africa, France, and the British Isles across most of Europe to Mongolia and Uttar Pradesh. It was recently reported from Turkey for the first time (Assing 2007a). The above specimens from Romania, Tunisia, Russia, Iran, and Israel represent new country records. Based on the revised material, the distribution of $A$. cuniculorum is of the Holo-Mediterranean type (Map 1). It remains unclear if the species really occurs in Brazil or if the specimen in the collection of the SDEI (see material examined) was mislabelled; it would seem rather unlikely for a nidicolous species to have been introduced to South America or to have arrived there on the wing. For a selection of additional records see Baranowski (1977), Beier \& Korge (2001), Fauvel (1902), Hansen et al. (1994), Joy (1932), Кoch (1968), Köhler (2000), Köhler \& Klausnitzer (1998), Likovský (1965a), Linke (1907), Lohse (1967), Normand (1934), and Tronquet (2006). However, since intra- and interspecific variation, as well as the taxonomic status in this species group were previously unclear and, furthermore, since previous identifications were primarily based on external characters, most of the previous records require revision, particularly those from the Eastern Palaearctic region. 
Based on the available evidence, $A$. cuniculorum is nidicolous and associated with the subterranean burrows and nests of various mammals: badger, fox, rabbit, hamster, ground squirrel, common vole (Baranowski 1979; BickHardt 1907; Gensicke 1960; Havelka 1964; Horion 1967; Joy 1932; WAGNER 1949; Weber 1942; material examined), exceptionally also mole (BEAR \& EvANS 1909) and sand martin (Welch 1997). According to Horion (1967), it was primarily observed from May through June and also repeatedly collected from the nests of mice and rats during the winter months. WeLCH (1997) reports occasional records from carrion and dead wood. The species has been collected with pitfall traps from the second half of March through May, suggesting that this is the period when dispersal takes place. One of the examined specimens was caught on the wing with a car-net in May. According to Maus et al. (1998), the dipteran host is the calliphorid fly Lucilia sericata.

\section{Aleochara (Xenochara) dalila Liкоvsкर́, 1984; revalidated (Figs 42-44)}

Aleochara (Polychara) peusi similis Likovskx́, 1965b: 53 f.; primary homonym.

Aleochara nidicola Lıkovskx́, 1973: 2; replacement name for A. similis; primary homonym.

Aleochara dalila Liкоvsкx́, 1984: 5; replacement name for $A$. nidicola.

\section{Type material examined:}

Holotype : "Mongolia, Central aimak, Bajan-Zurch sum, 1300 m, 30 km O. v. Ulan-Baator, Exp. Dr. Z. Kaszab, 1963 / Nr. 1, 16.VI.63 / Holotypus / Holotypus Aleochara peusi similis m., Zb. Likovský det. 64 / Aleochara dalila Likovský, det. V. Assing 2009" (HNHM).

\section{Additional material examined:}

Mongolia: 17 exs., Suchebaator aimak, Ongon elis, 10 km S Somon Chongor, 900 m, 3.-5.VIII.1965, leg. Kaszab (HNHM, cAss); 11 exs., Suchebaator aimak, Somon Dariganga, basalt mountain, 1270-1300 m, 7.VIII.1965, leg. Kaszab (HNHM, cAss); 4 exs., Suchebaator aimak, Molzog elis, 2 km S Somon Dariganga, 1150 m, 6.-7.VIII.1965, leg. Kaszab (HNHM, cAss); 1 ex., Chentej aimak, 7 km NE Somon Mörön, 1200 m, 28.VII.-21.VIII.1965, leg. Kaszab (HNHM); 2 exs., Central aimak, Cagan Dirschin chodag, Tola valley, $24 \mathrm{~km}$ from Somon Tariat, 1130 m, 24.VII.1966, leg. Kaszab (HNHM).

\section{Comment:}

Likovsкx́ (1965b) described A. peusi similis based on a single female from Mongolia. Having realised that $A$. similis was a primary homonym, LikovskÝ (1973) subsequently replaced the name with the nomen novum $A$. nidicola. However, this name, too, is a primary homonym and was replaced with the nomen novum $A$. dalila by the same author (Likovskŕ, 1984). According to Smetana (2004), $A$. dalila is a junior syonym of $A$. peusi. An examination of the above material from Mongolia, which was identified by Likovský as $A$. similis and $A$. nidicola, respectively, revealed that $A$. dalila is highly similar, both in external and sexual characters, and undoubtedly very closely related to $A$. cuniculorum. However, constant differences in the shape of the median lobe of the aedeagus and its internal structures suggest that $A$. dalila is a valid species.

\section{Redescription:}

External and secondary sexual characters as in A. cuniculorum.

$0^{*}$ : aedeagus with ventral process more strongly arcuate in lateral view (Fig. 42); apical part of flagellum much longer and basal part distinctly shorter than in A. cuniculorum (Figs 42-43).

i : spermatheca similar to that of $A$. cuniculorum (Fig. 44). 


\section{Distribution and bionomics:}

This species has been recorded only from several localities in Mongolia. The material listed above was collected at altitudes of 900-1300 m.

\section{Aleochara (Xenochara) breiti GANGLBAUER, 1897 (Figs 29-41, Map 2)}

Aleochara (Polychara) breiti Ganglbauer, 1897: $566 \mathrm{f}$.

Aleochara (Ophiochara) breiti BeRnHAUER, 1901: $483 \mathrm{f}$.

\section{Type material examined:}

Lectotype ${ }^{\star}$, present designation: "Umg. Wien, Breit / Breiti / Cotypus / Lectotypus ơ Aleochara breiti Ganglbauer, desig. V. Assing 2008 / Aleochara breiti, det. V. Assing 2008" (NHMW). Paralectotypes: 6 exs.: same data as lectotype (NHMW).

Additional material examined:

Austria: 5 exs., Wien, Rodaun, leg. Breit, Curti [2 exs. labelled "Typus Aleochara breiti Ganglbauer"] (NHMW); 10 exs., Wien env., leg. Breit, Hille, Hoffmann (HNHW, SDEI); 6 exs., Wien, Bisamberg, leg. Luze, etc. (SDEI, cAss); 1 ex., Mödling, 4.IV.1955, leg. Malicky (cAss); 7 exs., Mödling, leg. Wagner (SDEI); 2 exs., Niederösterreich, Ulrichskirchen, leg. Spurny (SDEI); 2 exs., Burgenland, Apetlon, pasture, pitfall, 1967, leg. Malicky (cAss); 1 \% , Burgenland, Illmitz, gravel pit, 4.VI.1962, leg. Weise (WMN); 1 ex., Leithagebirge, leg. Mandl (SDEI); 2 exs., Neusiedler See, suslik burrows, 3.IV.1913, leg. Pinker (NHMW, cAss).

Hungary: 2 exs., Neusiedler See (SDEI); 1 ex., locality not specified (SDEI).

\section{Comment:}

The original description is based on an unspecified number of syntypes collected by J. Breit "in den Gängen des Ziesels ... bei Wien" and by C. Chyzer "in Nordungarn" (Ganglbauer 1897). Seven syntypes were found in the collection of the NHMW; one of the males is here designated as the lectotype.

\section{Redescription:}

Size very variable; body length: 3.8-6.4 mm. Habitus as in Fig. 33. Coloration: head, pronotum, and abdomen blackish; elytra usually with extensive and weakly delimited reddish spot, in most specimens leaving only the scutellar region, as well as the anterior and lateral margins more or less distinctly infuscate; legs reddish to reddish-brown; antennae blackish-brown, with the basal 2-3 antennomeres usually slightly paler.

Head 1.12-1.16 times as wide as long; punctation somewhat variable, macropunctures fine to moderately fine, shallow, and rather sparse; interstices with micropunctation, on average wider than diameter of punctures; microsculpture absent; eyes conspicuously large and bulging, particularly so in large specimens (less convex in smaller specimens), 3-4 times as long as postocular region in dorsal view (Fig. 34). Antenna rather slender (Fig. 35).

Pronotum moderately convex in cross-section, 1.28-1.36 times as wide as long and 1.32-1.42 times as wide as head, widest in or slightly behind the middle; posterior angles weakly marked; punctation slightly more distinct, more defined, and denser than that of head; interstices with micropunctures, usually distinctly wider than diameter of macropunctures (except sometimes in posterior median area) and without microsculpture (Fig. 34).

Elytra approximately $0.75-0.80$ times as long as pronotum; posterior margin near posterior angles obliquely truncate, not sinuate; punctation usually distinctly coarser and denser than that of pro- 

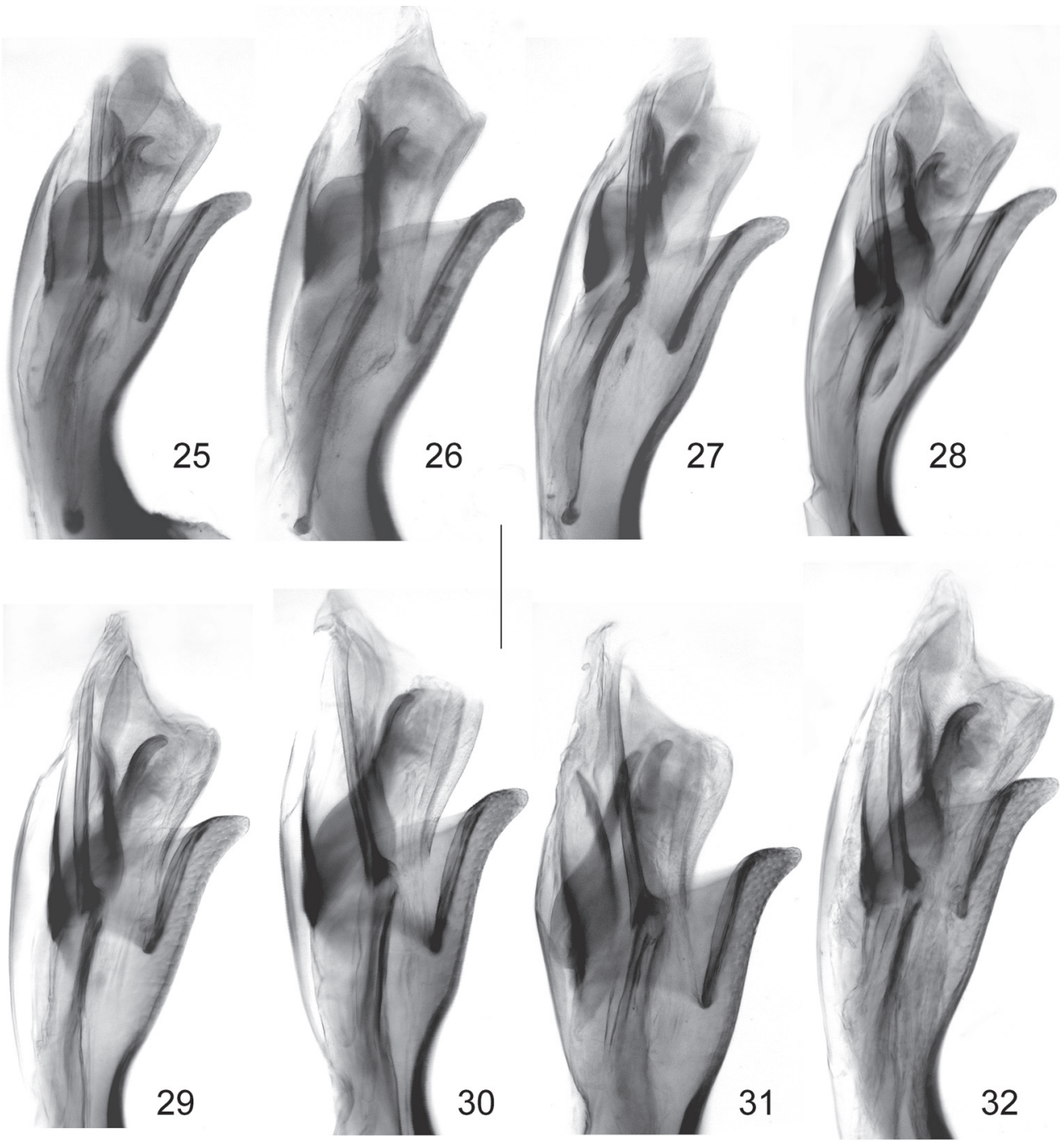

Figs 25-32: Aleochara cuniculorum KraAtz (25-28) and A. breiti Ganglbauer (29-32): apical portion of median lobe of aedeagus in lateral view of males from Niederösterreich $(25,29-31)$, Köthen, Germany (26), Borkum, Germany (27), Turkey (28), and Burgenland (32). Scale bar: $0.1 \mathrm{~mm}$.

notum; interstices usually narrower than diameter of punctures (Fig. 34). Legs long and slender; metatarsus approximately as long as metatibia; metatarsomere I slightly longer than the combined length of II and III.

Abdomen: tergites III-V with moderately deep anterior impressions, tergite VI without distinct anterior impression; tergite III, tergites IV-VII in anterior half (including anterior impression), and tergite VIII with dense or very dense and moderately coarse punctation, posterior half of tergites IV-VII with somewhat less coarse and less dense punctation; interstices without microsculpture (Fig. 36). 

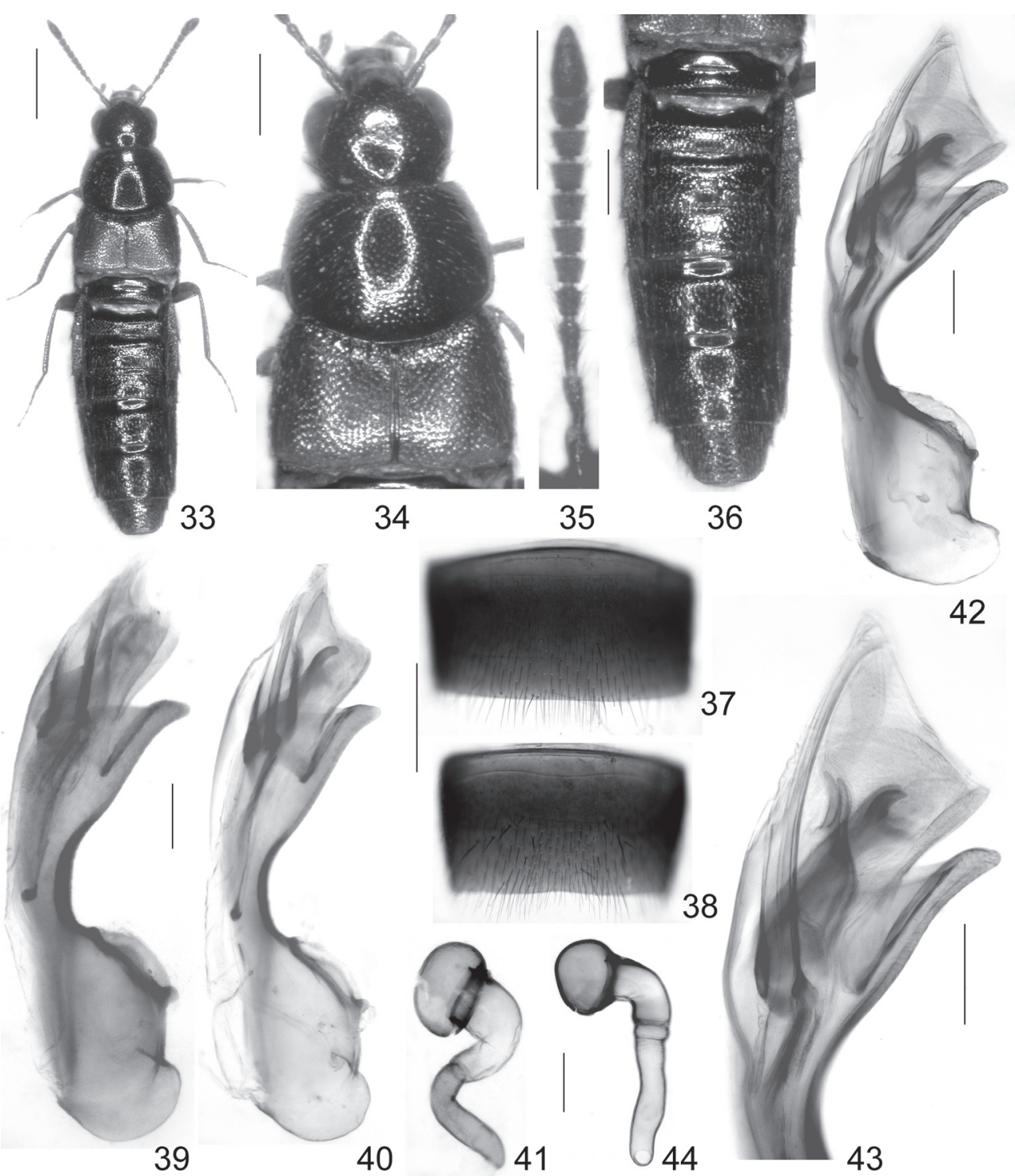

42

Figs 33-44: Aleochara breiti Ganglbauer (33-41; 39: lectotype) and A. dalila Likovskí (42-44): habitus (33); forebody (34); antennae (35); abdomen (36); male sternite VI (37); male sternite VII (38); median lobe of aedeagus in lateral view $(39-40,42)$; spermatheca $(41,44)$; apical portion of median lobe of aedeagus in lateral view (43). Scale bars: 33: $1.0 \mathrm{~mm}$; 34-38: $0.5 \mathrm{~mm}$; 39-44: $0.1 \mathrm{~mm}$.

$\mathrm{o}^{\star}$ : posterior margin of tergite VIII weakly and broadly concave; sternite VI at posterior margin with numerous, in the middle particularly dense long marginal setae (Fig. 37); posterior portion of sternite VII with dense long setae, posterior margin in the middle weakly concave (Fig. 38); posterior margin of sternite VIII distinctly produced in the middle; median lobe of aedeagus 0.60-0.72 mm long, ventral process relatively stout (Fig. 39-40); internal structures of similar arrangement as in $A$. cuniculorum, but flagellum and apical structures of slightly different shape (Figs 29-32). 


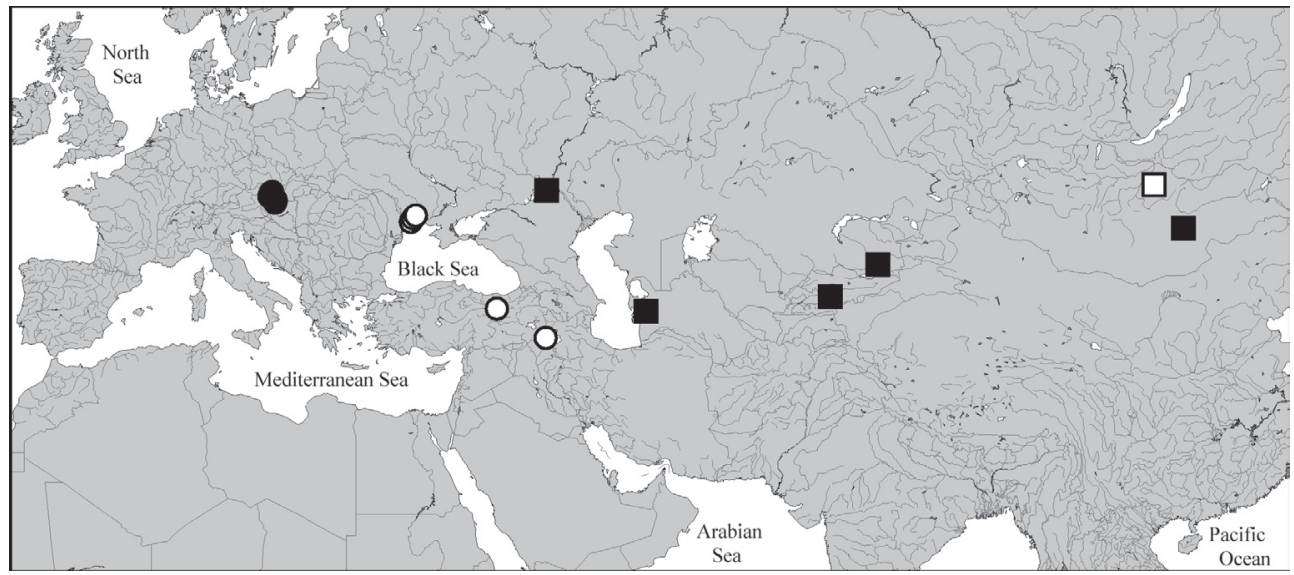

Map 2: Distributions of species of the Aleochara cuniculorum group in the Palaearctic region, based on revised records: A. breiti Ganglbauer (filled circles), A. gontarenkoi sp. n. (open circles), A. longipes Likovskí (filled squares), and $A$. utriculata sp. n. (open square).

ㄴ p posterior margin of tergite VIII truncate or weakly concave; posterior margin of sternite VIII broadly convex; spermatheca as in Fig. 41.

\section{Comparative notes:}

The species is distinguished from other nidicolous large-eyed congeners particularly by the distinctly transverse head, as well as by the shape and internal structures of the aedeagus.

\section{Distribution and bionomics:}

The distribution of this species is remarkably restricted (Map 2). According to Horion (1967), Likovský (1974), and Smetana (2004), A. breiti is distributed in the southeast of Central Europe (Austria, Czech Republic, Slovakia), and Hungary. Recently, it was reported from Romania for the first time (STAN \& Chimişliu 2005). For additional records see Jászay \& Majzlan (2004) and LikovskÝ (1965a). Staniec (1992) reports the species from southeastern Poland, but the illustrations of the habitus and the primary sexual characters provided with his records, as well as the fact that the specimens were collected from burrows of Spermophilus suslicus (GüLDENSTÄDT, 1779) suggest that these records refer to A. gontarenkoi (see below). The same may apply to the record from Romania, where Spermophilus suslicus is present, too. Similarly, the presence of this species in the Czech Republic requires confirmation. In the material from the collections examined, the species was frequently misidentified.

On numerous occasions, $A$. breiti has been collected from the burrows of the European ground squirrel, Spermophilus citellus (Linné, 1766), also known as the European suslik (or souslik). According to Bernhauer (1936a) and Horion (1967), the species is found by sifting the soil and grass roots around the entrance holes of the burrows and by examining the soil from within the burrows in spring (March through May). Bernhauer (1936a) reports the species also from mole nests in areas where ground squirrels are present, too. Franz (1938) found it in fox burrows. JÁszaY \& MAJZlan (2004) collected two specimens with a malaise trap in May-June. Three of the specimens listed above were caught with pitfall traps, one of them in April. 
Aleochara (Xenochara) gontarenkoi sp. n. (Figs 45-57, Map 2)

\section{Type material:}

Holotype $\sigma^{*}$ : "Ukraine, Odessa, Olexandrivka, suslik hole, 2.IV.2006, leg. A. Gontarenko / Holotypus ơ Aleochara gontarenkoi sp. n., det. V. Assing 2008" (cAss). Paratypes: 1 o , 2 ㅇ : same data as holotype (cGon, cAss); $2 o^{\star} o^{\star}, 4$ ㅇ + : "Ukraine, Odessa, Korsuncy, suslik hole, 7.IV.1996, leg. A. Gontarenko" (cGon, cAss); 3 우: "Ukraine - Odessa, shore of Tiligul liman, Kalinivka, suslik hole, 9.IV.006, leg. A. Gontarenko" (cGon, cAss); 1 o , 2 exs.: "Türkei-Exped. 1966, Naturhist. Mus. Wien / Yüksekova (Hakkari), 26.V.1966 / -Van, 2400 m, 26.V.1966 / ZieselbauEingang / Aleochara (Polychara) breiti Gglb." (NHMW, cAss); 1 q : "Turkey (Erzinçan), 17 km NW of Erzinçan, 19-V-1990, leg. P. Kanaar" (cWun).

\section{Description:}

Body length: 3.9-7.2 mm. Habitus (holotype) as in Fig. 45. Coloration: head, pronotum, and abdomen blackish; elytral disc blackish, posteriorly with more or less sharply delimited triangular reddish spot; legs reddish to reddish-brown; antennae blackish-brown.

Head 1.07-1.11 times as wide as long; punctation fine and sparse; interstices 2-3 times as wide as diameter of macropunctures, with micropunctation, but without microsculpture; eyes large and bulging, 2-2.5 times as long as postocular region in dorsal view (Fig. 46). Antenna similar to that of $A$. breiti (Fig. 47).

Pronotum 1.28-1.35 times as wide as long and 1.45-1.55 times as wide as head, widest in or slightly behind the middle (Fig. 46); posterior angles weakly marked; punctation more distinct, more defined, and denser than that of head; interstices wider than diameter of punctures and without microsculpture.

Elytra approximately 0.8 times as long as pronotum; posterior margin near posterior angles obliquely truncate, not sinuate; punctation coarser and denser than that of pronotum (Fig. 46); interstices narrower than diameter of punctures. Legs long and slender; metatarsus approximately as long as metatibia; metatarsomere I slightly longer than the combined length of II and III.

Abdomen: tergites III-V with moderately deep anterior impressions, tergite VI without distinct anterior impression; tergites III-VII anteriorly with very dense and moderately coarse punctation, in posterior half with somewhat less coarse and dense punctation; interstices of tergites III-VII without microsculpture (Fig. 48); posterior margin of tergite VIII weakly and broadly concave (Fig. 49).

$\sigma^{*}$ : sternites VI-VIII similar to those of $A$. breiti, but sternites VI-VII with somewhat less dense pubescence posteriorly (Figs 50-51); median lobe of aedeagus approximately $0.6 \mathrm{~mm}$ long, shaped as in Figs 52-54.

o : sternite VIII broadly convex posteriorly (Fig. 55); spermatheca as in Figs 56-57.

\section{Etymology:}

The species is dedicated to Andrej Gontarenko, a Ukrainian staphylinidologist, who collected most of the type specimens of this species.

\section{Comparative notes:}

Both in external and sexual characters, this species is highly similar to A. breiti, from which it is distinguished by the less transverse and smaller head (in relation to pronotum), the slightly smaller eyes, the denser pubescence and punctation of the pronotum, the more delimited and 

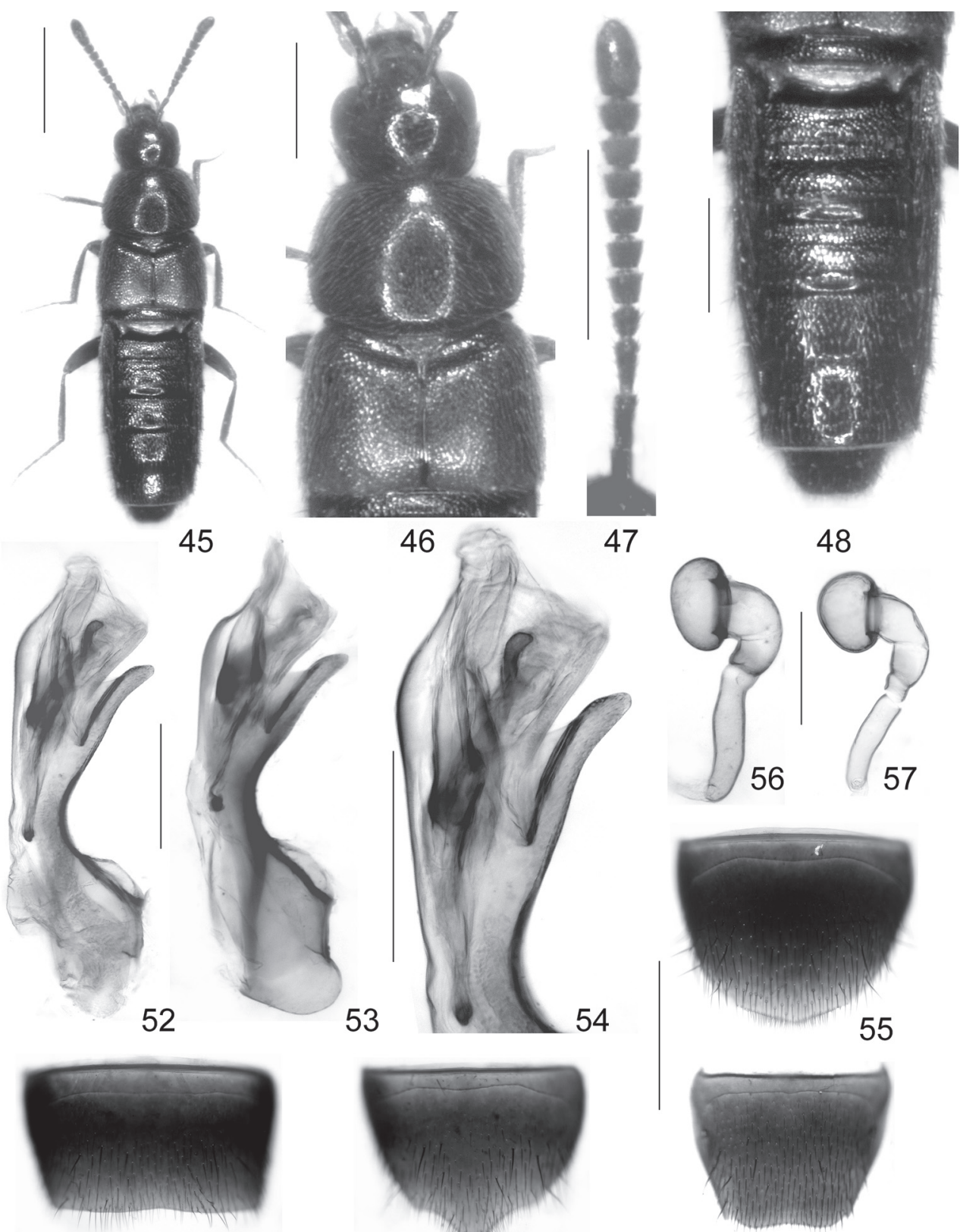

50

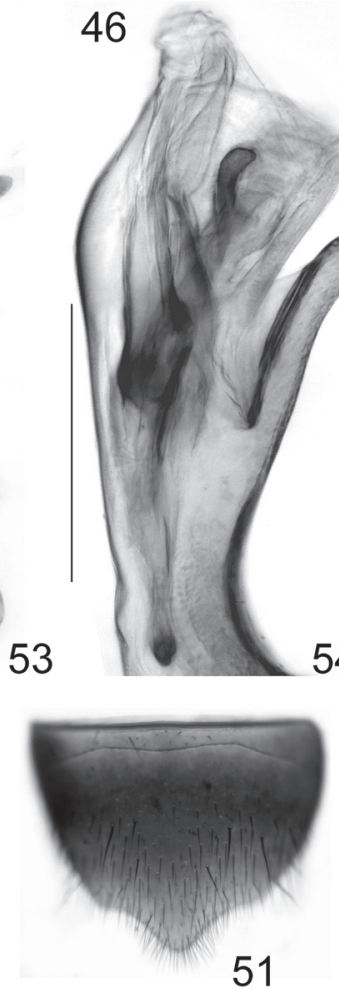

47

48
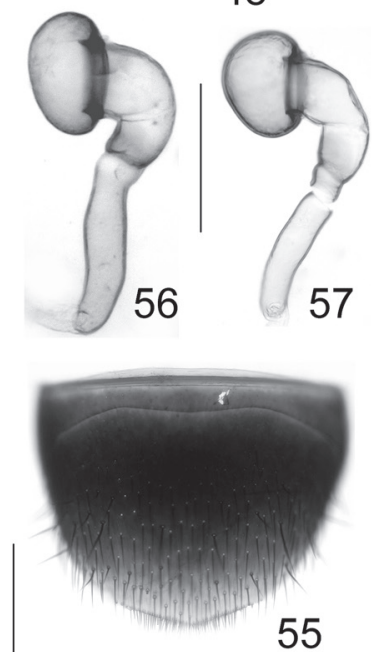

54

Figs 45-57: Aleochara gontarenkoi sp. n.: habitus (45); forebody (46); antennae (47); abdomen (48); male tergite VIII (49); male sternite VII (50); male sternite VIII (51); median lobe of aedeagus in lateral view of males from Ukraine (52) and Turkey (53); apical portion of median lobe of aedeagus in lateral view (54); female sternite VIII (55); spermatheca (56-57). Scale bars: 45: $1.0 \mathrm{~mm}$; 46-51, 55: $0.5 \mathrm{~mm}$; 52-54, 56-57: $0.2 \mathrm{~mm}$. 
on average distinctly smaller reddish spot on the elytra, the morphology of the aedeagus (apex of ventral process more slender in lateral view), as well as by the slightly different shape of the spermathecal capsule. Aleochara gontarenkoi is separated from A. cuniculorum particularly by the less convex pronotum, the larger and more convex eyes, the broader and more transverse head, and by the morphology of the aedeagus, particularly the shorter ventral process (basal portion as long as apical portion; $A$. cuniculorum: basal portion distinctly longer than apical portion). From both $A$. breiti and $A$. cuniculorum, it is distinguished by the different shape of the apical internal structures of the aedeagus.

Due to the pronounced intraspecific variation in size, proportions, and coloration of both A. breiti and A. gontarenkoi, the alternative hypothesis that both morphs refer to one and the same variable species and that the observed difference are an expression of intra- rather than interspecific variation had to be considered. However, the aedeagal differences between $A$. breiti and $A$. cuniculorum, two species that are readily separated based on head shape alone, are not very pronounced either. Also, in all the examined males of $A$. breiti and $A$. gontarenkoi, the apical internal structures of the aedeagus are absolutely constant, suggesting that both morphs represent different entities on the specific level. More material from other localities and regions is needed to verify this hypothesis.

\section{Distribution and bionomics:}

Confirmed records of this species have become known only from some localities near Odessa, Ukraine, and two localities in southeastern and eastern Anatolia (Map 2). Based on the illustrations of the habitus and the primary sexual characters provided by STANIEC (1992), as well as the fact that his specimens were collected from burrows of Spermophilus suslicus, previous records of A. breiti from southeastern Poland also refer to this species; the same may be true for the recent record from Romania (STAN \& CHImişLiu 2005), where S. suslicus is present, too.

All the type specimens were collected from suslik burrows, the material from Ukraine from the burrows of the speckled (or spotted) ground squirrel, Spermophilus suslicus (GonTarenko pers. comm.). According to ÖZKuRT et al. (2007), the only Spermophilus species present in southeastern Anatolia is $S$. xanthoprymnus.

\section{Aleochara (Xenochara) longipes LıкоvsкÝ, 1965 (Figs 58-69, Map 2)}

Aleochara (Polychara) longipes Likovsкx́, 1965b: 49 ff.

\section{Type material examined:}

Holotype + : "Mongolia, Ostgobi aimak, Ulan chosu, 1200 m, 38 km SO v. Čojren, Exp. Dr. Z. Kaszab, 1963 / Nr. 65, 30.VI.63 / Holotypus / Holotypus Aleochara longipes m., Zb. Likovský det. 64 / Aleochara longipes Likovský, det. V. Assing 2009" (HNHM).

Additional material examined:

Kazakhstan: $2 \sigma^{\star} \sigma^{\star}$, E Zailyiskyi Alatau, Belshabdar river, 1300 m, 27.VI.2002, leg. Putchkov (cAss). Kyrgyzstan: 1 ㅇ, Osch, Andi-Shan reservoir, 4049'N, 73¹0'E, 900 m, 18.-19.VII.2003, leg. L. Schmidt (cAss).

Turkmenistan: 1 \% , NE Nebit Dag, "Gr. Balachan, Dschebell" [= Uly Balkan Gershi, = Khrebet Bol'shiye Balkhany, = Balkhan Mts.; 3940'N, 5430'E], 1898, leg. Hauser (cAss).

Russia: 1 ㅇ, Wolgograd, Sarepta, leg. Seidlitz (NHMW).

Locality not identified: $1 \sigma^{*}$, "Turkest. occ., Jagn. Pachut [?]" (NHMW). 

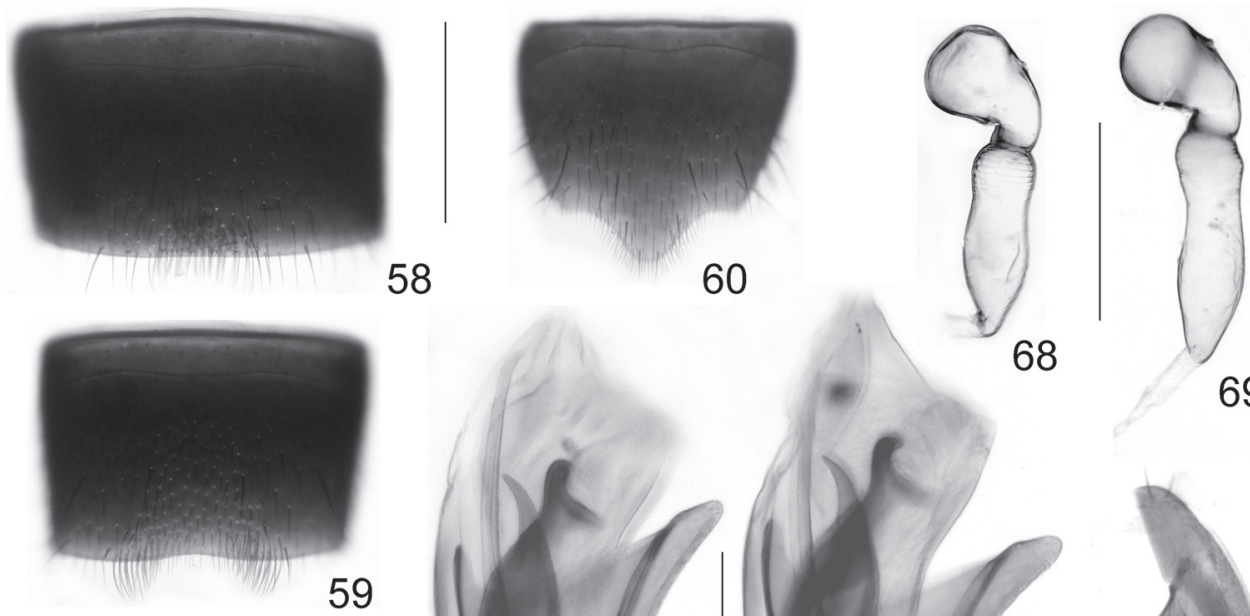

58

69

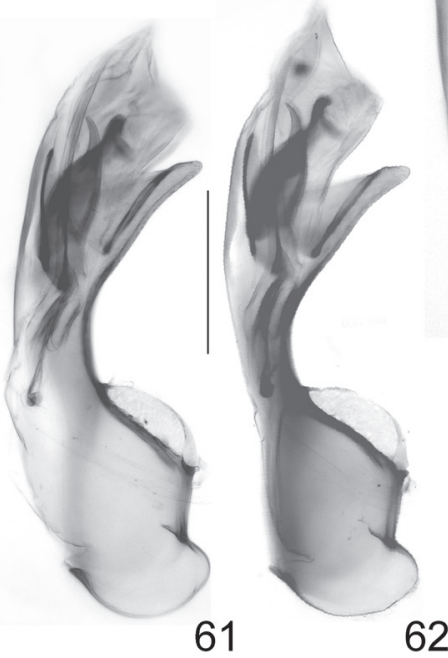

62
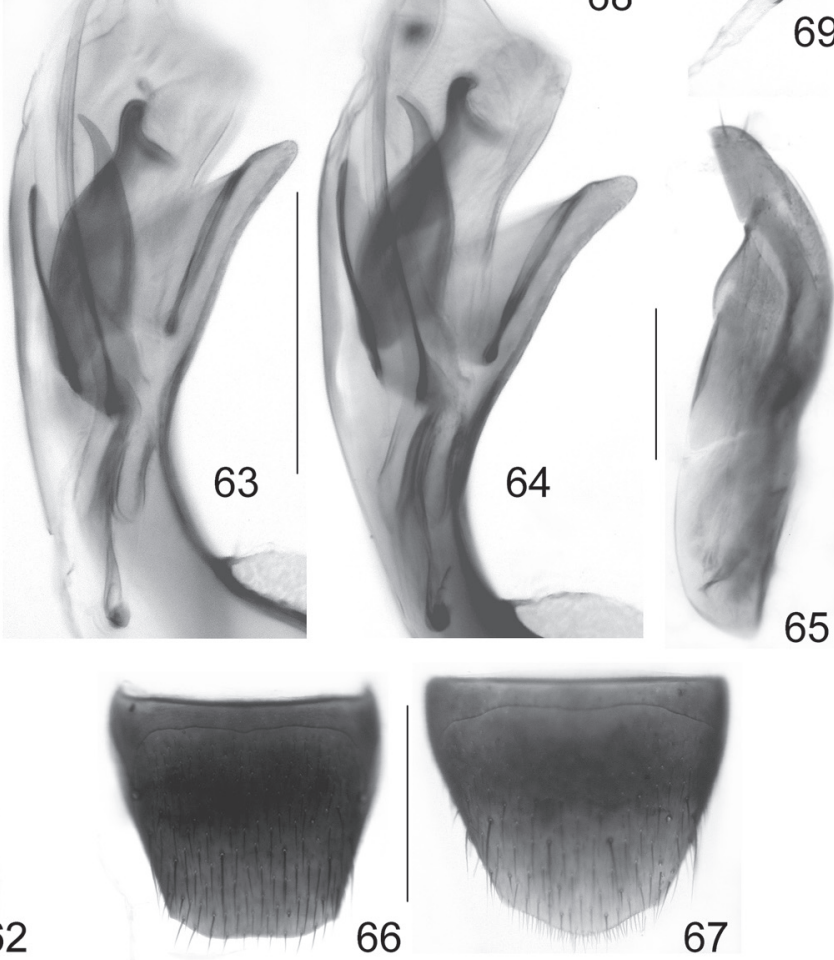

65

Figs 58-69: Aleochara longipes Likovskx́: male sternite VI (58); male sternite VII (59); male sternite VIII (60); median lobe of aedeagus in lateral view of males from Turkestan (61) and Kazakhstan (62); apical portion of median lobe of aedeagus in lateral view of males from Turkestan (63) and Kazakhstan (64); paramere (65); female tergite VIII (66); female sternite VIII (67); spermatheca of holotype (68) and of female from Kyrgyzstan (69). Scale bars: 58-60, 66-67: 0.5 mm; 61-65, 68-69: $0.2 \mathrm{~mm}$.

\section{Comment:}

The species was described from a single female from Mongolia (Likovskx́ 1965b). The material reported as A. longipes from Mongolia by Likovský (1968) was misidentified and refers to a different species (see the following section).

\section{Redescription:}

The species resembles small specimens of $A$. cuniculorum with a well-delimited triangular reddish spot on the elytra, but is externally distinguished by a relatively large head, a relatively slender pronotum (approximately 1.3 times as wide as long and 1.4 times as wide as head), as well as by 
the rather fine and sparse punctation of the abdomen (even anterior impressions of tergites III-V rather sparsely punctate).

$\sigma^{7}$ : sternite VI posteriorly in the middle with cluster of dense long setae (Fig. 58); posterior margin of sternite VII weakly concave in the middle, on either side of middle with conspicuous cluster of dense long setae (Fig. 59); sternite VIII similar to that of A. cuniculorum and allied species (Fig. 60); median lobe of aedeagus approximately $0.55 \mathrm{~mm}$ long, shaped as in Figs 61-64; paramere as in Fig. 65.

ㅇ: tergite VIII similar to that of $A$. cuniculorum (Fig. 66); sternite VIII weakly pointed posteriorly (Fig. 67); spermatheca with relatively large and long proximal portion of the capsule (Figs 68-69).

\section{Comparative notes:}

The shape of the median lobe and the internal structures are most similar to those of $A$. dalila from Mongolia. From this species, as well as from all other species of the A. cuniculorum group, Aleochara longipes is best distinguished by the male and female sexual characters, particularly the chaetotaxy of sternite VII, the morphology of the aedeagus, and the distinctive shape of the spermatheca.

\section{Distribution:}

The species is currently known only from Mongolia, Kyrgyzstan, Kazakhstan, and SW Russia (Map 2). The specimens from Russia, Turkmenistan, Kyrgyzstan and Kazakhstan represent new country records.

\section{Aleochara (Xenochara) utriculata nov. sp. (Figs 70-83, Map 2)}

Aleochara longipes: Lıкоvsкú (1968) nec Liкоvsкú (1965b).

\section{Type material:}

Holotype ơ: "Mongolia, Central aimak, $126 \mathrm{~km} \mathrm{~N} \mathrm{v.} \mathrm{Ulan-Baator,} \mathrm{am} \mathrm{Wege,} 1100$ m, Exp. Dr. Z. Kaszab, 1964 / Nr. 290, 9.VII.64 / longipes M., det. Z. Likovsky / Holotypus ơ Aleochara utriculata sp. n., det. V. Assing 2009" (HNHM). Paratypes: 15 exs.: same data as holotype (HNHM, cAss).

\section{Description:}

Body length variable: 3.0-4.9 mm. Habitus as in Fig. 70. Coloration: head and abdomen black; antennae, pronotum, and elytra blackish-brown, the latter posteriorly with yellowish to reddishyellow spot of triangular shape and variable size; legs brown to dark-brown.

Head approximately as wide as long or weakly transverse; punctation very fine and sparse; interstices on average 3-6 times as wide as diameter of punctures, with or without very shallow traces of microsculpture; eyes moderately large and moderately convex, longer than (but distinctly less than twice as long as) postocular region in dorsal view (Fig. 71). Antenna rather slender; antennomere IV weakly transverse and distinctly shorter and narrower than V; V-X only very weakly increasing in width, $\mathrm{X}$ only slightly wider than $\mathrm{V}$ and at most 1.5 times as wide as long (Fig. 72).

Pronotum approximately 1.25-1.30 times as wide as long and 1.40-1.45 times as wide as head; widest slightly behind the middle; posterior angles weakly marked; punctation less fine and denser than that of head (Fig. 71). 

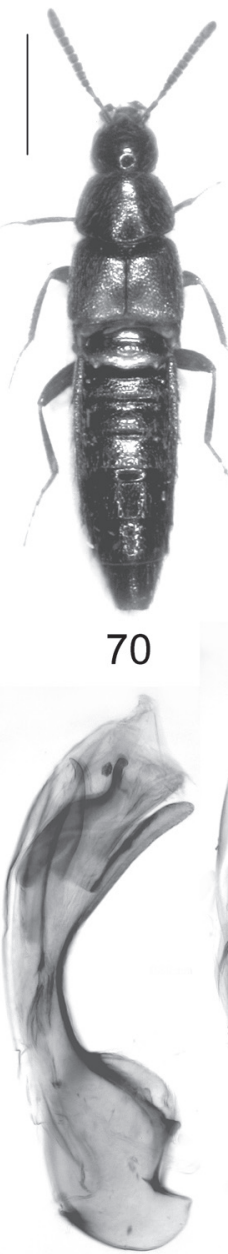

75

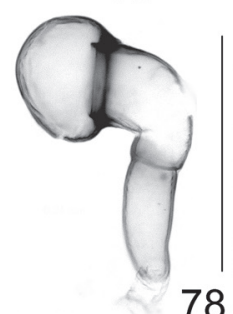

78

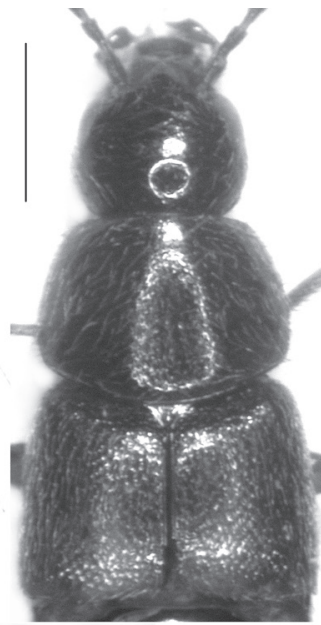

71

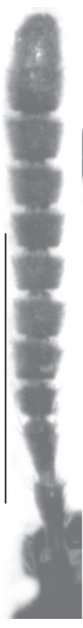

72

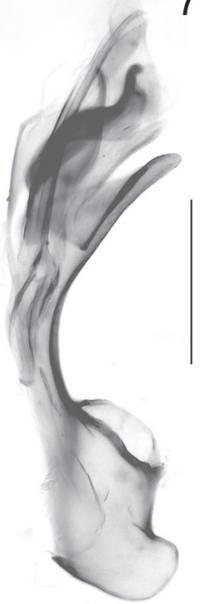

76

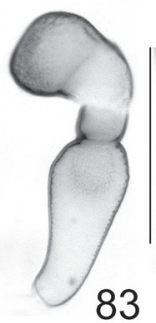

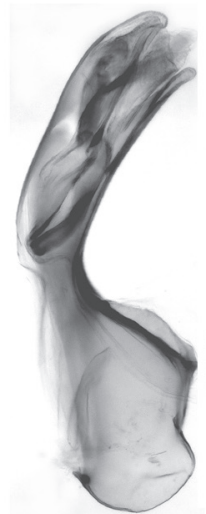

81
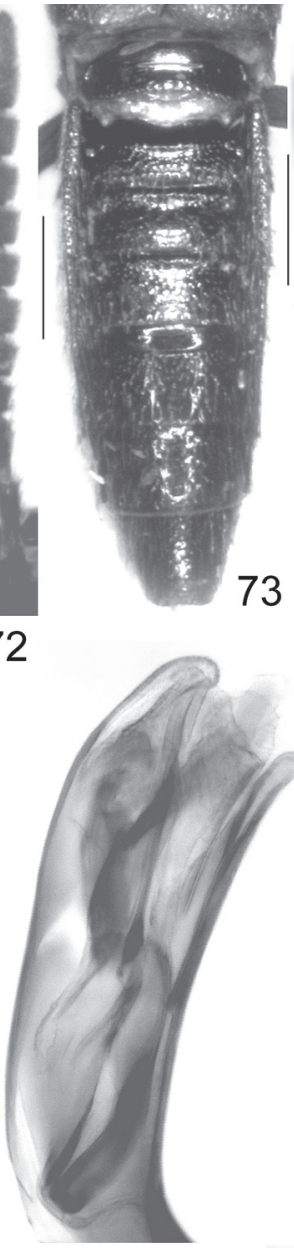

82

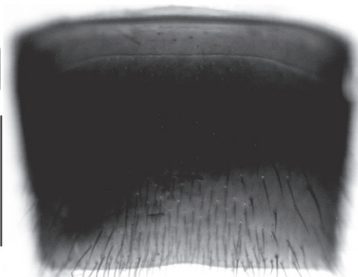

74
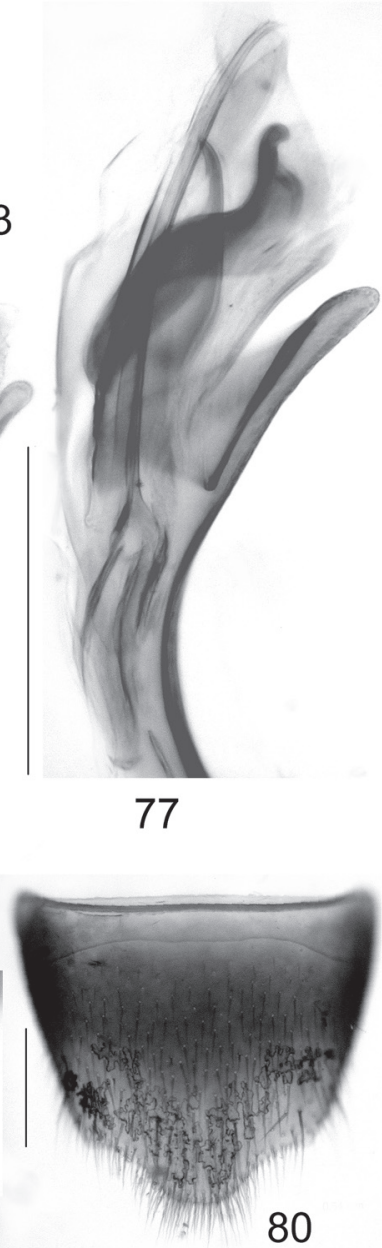

Figs 70-83: Aleochara utriculata sp. n. (70-78) and A.parvicornis FAuvel (79-83; 79-82: holotype of A. gracilis LikovsкÝ; 83: holotype of A. parvicornis FauveL): habitus (70); forebody (71); antenna (72); abdomen (73); male sternite VII (74); median lobe of aedeagus in lateral view (75-76, 81); apical portion of median lobe of aedeagus in lateral view $(77,82)$; spermatheca $(78,83)$; posterior portion of male tergite VIII (79); male sternite VIII (80). Scale bars: 70: $1.0 \mathrm{~mm}$; 71-74: 0.5 mm; 75-83: $0.2 \mathrm{~mm}$. 
Elytra approximately 0.8 times as long as pronotum (Fig. 71); posterior margin near posterior angles obliquely truncate, very weakly sinuate; punctation coarser and denser than that of pronotum; interstices without microsculpture. Legs long and slender; metatarsus approximately 1.1 times as long as metatibia; metatarsomere I elongate, usually slightly longer than the combined length of II and III.

Abdomen widest at segment IV; tergites III-V with moderately deep anterior impressions, tergite VI without anterior impression; punctation of anterior tergites (including anterior impressions) dense and moderately fine, that of posterior tergites distinctly sparser; interstices without distinct microsculpture and glossy (Fig. 73).

$\sigma^{\star}$ : posterior margin of tergite VIII weakly concave; sternite VII with truncate or weakly concave posterior margin, pubescence near posterior margin rather dense, long, and fine, not arranged in distinct clusters (Fig. 74); posterior margin of sternite VIII distinctly produced posteriorly; median lobe of aedeagus with slender ventral process and internal structures of distinctive shape (Figs 75-77).

ㅇ: sternite VIII weakly convex posteriorly; spermatheca as in Fig. 78.

\section{Etymology:}

The name (Latin, adjective: with a small tube) refers to the short proximal part of the capsule, one of the characters distinguishing this species from the similar A. longipes.

\section{Comparative notes:}

Aleochara utriculata is distinguished from other species of the A. cuniculorum group particularly by the shape and the characteristic internal structures of the median lobe of the aedeagus, as well as by the shape of the spermatheca, from the similar $A$. longipes also by the chaetotaxy of the male sternite VII.

\section{Distribution and bionomics:}

The known distribution of this species is confined to the type locality in Mongolia (Map 2). The type specimens were collected at an altitude of $1100 \mathrm{~m}$.

\section{The species of the Aleochara parvicornis group}

Like the representatives of the $A$. cuniculorum group, the two species placed in the $A$. parvicornis group below are apparently nidicolous. They are separated from the species of the $A$. cuniculorum group as follows: body of conspicuously slender and parallel shape, with the head rather large in relation to pronotum; legs slender; median lobe of aedeagus slender (ventral view) and with characteristic internal structures.

\section{Aleochara (Xenochara) parvicornis FAUVEL, 1900 (Figs 79-90, Map 3)}

Aleochara parvicornis FAUveL, 1900: 248.

Aleochara (Rheochara) bobaci KRÁsA, 1933: 134 f.; syn. n.

Aleochara (Isochara) gracilis Likovskŕ, 1965b: 48 f.; syn. n.; preocc.

Type material examined:

Aleochara parvicornis: Holotype $:$ : "Sarepta / parvicornis Fvl. / Type / Coll. I. R. Sc. N. B. / Holo- 
typus ㅇ Aleochara parvicornis Fauvel, rev. V. Assing 2009 / Aleochara parvicornis Fauvel, det. V. Assing 2009" (IRSNB).

Aleochara gracilis: Holotype ơ: "Mongolia, Ostgobi aimak, 13 km SSO v. Chara-Eireg, $1100 \mathrm{~m}$, Exp. Dr. Z. Kaszab, 1963 / Nr. 56, 29.VI.63 / Holotypus / Holotypus Aleochara gracilis m., Zb. Likovský det. 64 / Aleochara parvicornis Fauvel, det. V. Assing 2009 (HNHM).

Additional material examined:

Russia: $1 \sigma^{\star}$, Samarskaja oblast, Tockoe (cAss).

Mongolia: 1 †, 20 km S Somon Delgerzogt, 1480 m, 9.VI.1967, leg. Kaszab ["Allotypus 1970, Aleochara gracilis Likowsky [sic]" (HNHM); $1 \sigma^{\star}$, Archangaj aimak, Changaj range, $8 \mathrm{~km}$ W Somon Urdtamir, 1620 m, 19.VI.1966, leg. Kaszab (HNHM).

\section{Comment:}

The original description of $A$. parvicornis is based on a single specimen from "Sarepta (Becker)" (Fauvel 1900). The holotype, a female, was located in the collections of the IRSNB and examined. The species was previously attributed to the subgenus Ophiochara.

Aleochara bobaci was described from at least 17 syntypes collected in Tockoje (KRÁsA 1933). A lectotype was designated by LikovskÝ (1965b). The present interpretation of this species is based on a male from the type locality.

Likovsкx́ (1965b) described $A$. gracilis explicitly from a single male holotype from "Mongolia, Ostgobi aimak, $13 \mathrm{~km}$ SSO von Chara-Eireg"; paratypes are not mentioned in the original description. The type label attached to the female from Mongolia listed as additional material above is a curator label. The holotype of $A$. gracilis and the additional material from Mongolia, which was identified by Likovský as $A$. gracilis, are conspecific with the holotype of $A$. parvicornis. The aedeagus and spermatheca of the Mongolian material (A. gracilis) are identical to those of the material seen from Russia (A. parvicornis, A. bobaci). Hence the synonymies proposed above. Moreover, A. gracilis LikovskÝ is a secondary junior homonym of Aleochara gracilis (SHARP 1883) from Central America.

\section{Redescription:}

Body length 3.2-5.3 mm. Habitus as in Fig. 84. Coloration: head blackish-brown; pronotum and abdomen dark-brown, with the abdominal apex somewhat paler; elytra yellowish, with the anterior margin and usually also the suture narrowly infuscate; legs and antennae yellowish to reddish-yellow; antennomeres IV-XI sometimes weakly infuscate.

Head transverse, approximately 1.05-1.15 times as wide as long (Fig. 85); punctation fine, shallow, and moderately dense; interstices with micropunctation of variable density; eyes large and more or less strongly convex, approximately twice as long as postocular region in dorsal view or longer. Antennae short; antennomere III slightly shorter than II; IV moderately transverse; $\mathrm{V}-\mathrm{X}$ of gradually increasing width and increasingly transverse; $\mathrm{X}$ almost twice as wide as long (Fig. 86).

Pronotum approximately 1.30-1.35 times as wide as long and 1.25-1.35 times as wide as head; punctation fine and conspicuously dense; interstices with micropunctation.

Elytra approximately 0.75 times as long and 1.1 times as wide as pronotum; punctation very dense and and rather fine, less defined than that of pronotum (Fig. 85). Legs moderately long; metatibia $0.55-0.80 \mathrm{~mm}$ long; metatarsus approximately as long as metatibia; metatarsomere I slightly to distinctly longer than the combined length of II and III. 


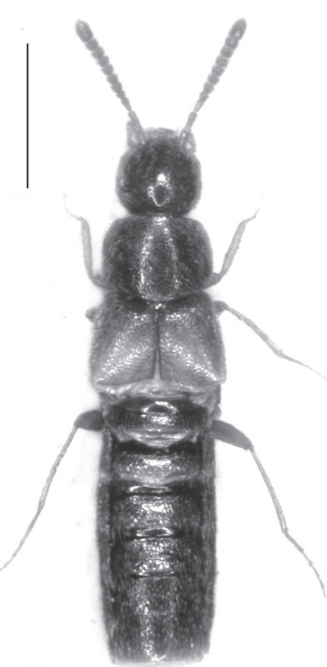

84

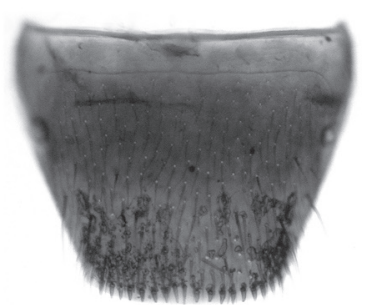

88

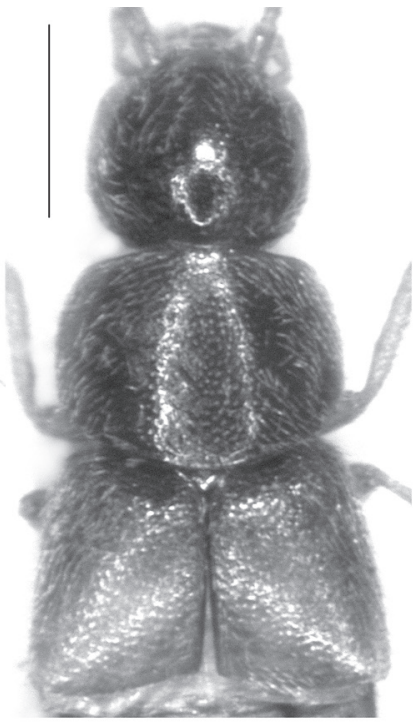

85

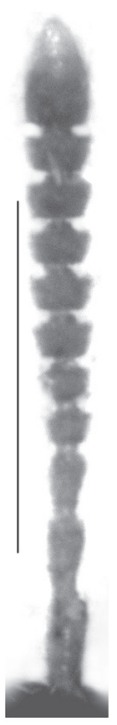

86

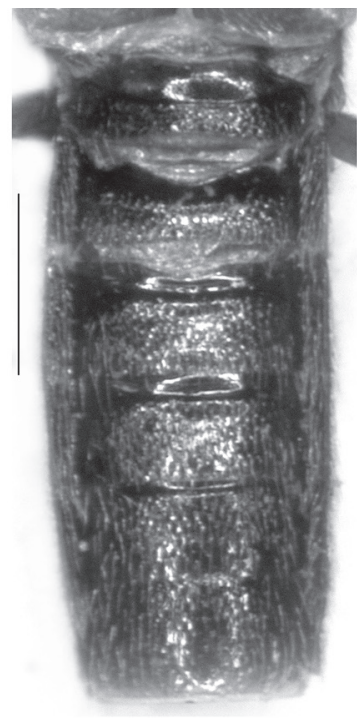

87

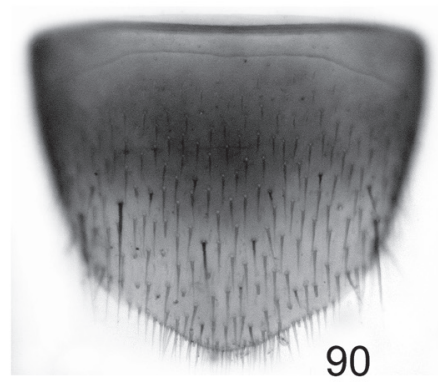

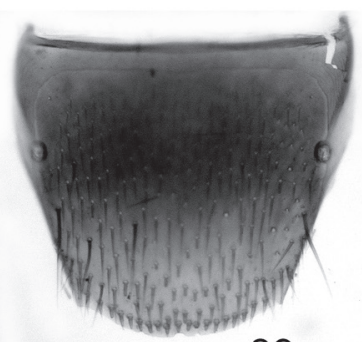

89
90

Figs 84-90: Aleochara parvicornis LikovsкÝ (84-88: holotype of A. gracilis LikovsкÝ; 89-90: holotype of A. parvicornis FAUVEL): habitus (84); forebody (85); antenna (86); abdomen (87); male tergite VIII (88); female tergite VIII (89); female sternite VIII (90). Scale bars: 84: $1.0 \mathrm{~mm}$; 85-90: $0.5 \mathrm{~mm}$.

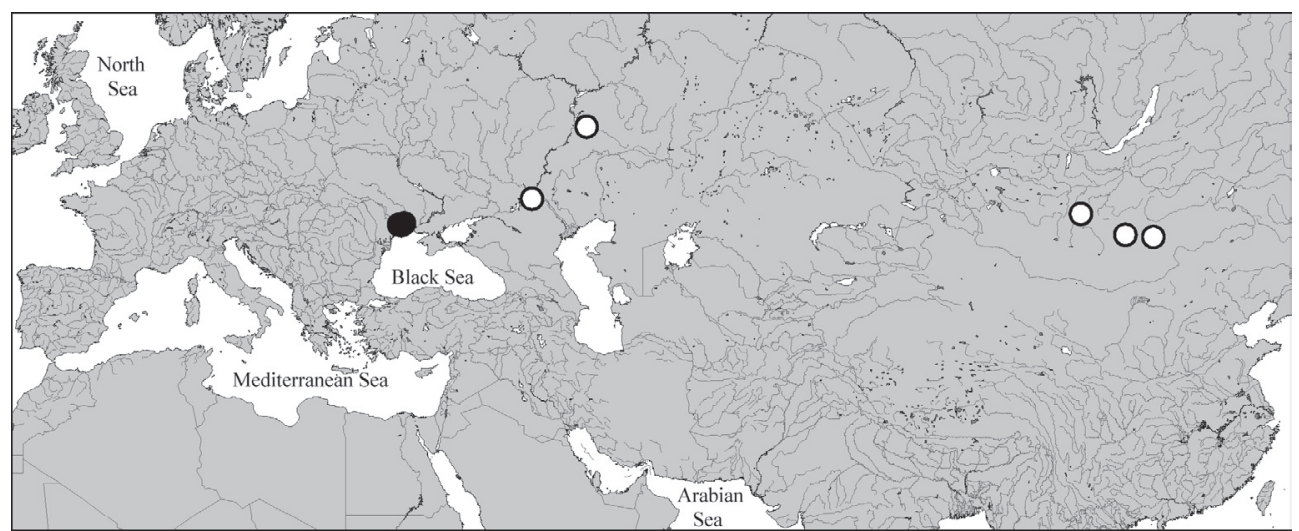

Map 3: Distributions of the species of the Aleochara parvicornis group in the Palaearctic region, based on revised records: A. parvicornis FAUvel (open circles) and A. suslica sp. n. (filled circles). 
Abdomen with segments III-VI of subequal width (Fig. 87), posteriorly only weakly tapering; tergites III-V anteriorly with shallow impressions; punctation rather coarse and conspicuously dense; posterior margin of tergite VIII with modified short and stout marginal setae (Figs 79, 88-89).

$\sigma^{*}$ : tergite VIII with weakly convex posterior margin (Figs 79, 88); sternite VIII posteriorly strongly produced (Fig. 80); aedeagus as in Figs 81-82.

9 : posterior margin of tergite VIII convex (Fig. 89); posterior margin of sternite VIII weakly produced, almost obtusely angled in the middle (Fig. 90); spermatheca as in Fig. 83.

\section{Comparative notes:}

This highly distinctive species is readily distinguished from its congeners based on external characters alone, particularly the slender and almost parallel body, the dense punctation, the coloration, the large eyes, and the chaetotaxy of tergite VIII. The aedeagus somewhat resembles that of the following species in general morphology and lacks the characteristic arrangement of internal structures typical of the A. cuniculorum group.

\section{Distribution:}

This species has been recorded from the environs of Volgograd and Samara, southwestern Russia, and from three localities in Mongolia (Map 3), suggesting that it is probably rare and much more widespread than currently known. The type material of $A$. bobaci was collected from the burrows of Marmota bobak (MüLLER), the bobak (or steppe) marmot (KRÁsA 1933).

\section{Aleochara (Xenochara) suslica nov. sp. (Figs 91-104, Map 3)}

\section{Type material:}

Holotype $0^{\text {t: }}$ "Ukraine - Odessa, shore of Tiligul liman, Kalinivka, suslik hole, 9.IV.2006, A. Gontarenko / Holotypus ơ Aleochara suslica sp. n., det. V. Assing 2008" (cAss). Paratypes: 3 우 same data as holotype (cGon, cAss); $3 \sigma^{\star} \sigma^{\star}$ : "Ukraine - Odessa, shore of Tiligul liman, Kalinivka, mouse nest, 13.IV.2005, A. Gontarenko" (cGon, cAss); $1 \sigma^{\star}:$ "Ukraine, Odessa, Korsuncy, suslik hole, 7.IV.1996, leg. A. Gontarenko" (cAss); 1 ð : "Odessa obl., l. bank of Khadzhibey liman, vic. Morozovka [recte: Morozivka], 17.04.005, leg. Bondarenko D. A. / under stone" (cGon).

\section{Description:}

Body length variable: 4.0-7.0 mm. Habitus as in Fig. 91. Usual coloration (8 type specimens): head, pronotum, and abdomen blackish; elytral disc blackish with reddish posterior margin, or blackish with more or less extensive, weakly delimited reddish spot in posterior portion; legs dark-brown, with the tarsi and sometimes also the tibiae reddish to reddish-brown; antennae blackish-brown. Rarely (one paratype), the legs, antennae, the abdominal apex, and most of the elytral disc may be reddish.

Head 1.10-1.13 times as wide as long; punctation moderately fine and shallow; interstices on average as wide as, or slightly wider than diameter of macropunctures, with micropunctation, but without microsculpture; eyes large and bulging, approximately twice as long as postocular region in dorsal view, or nearly so (Fig. 92). Antenna similar to that of $A$. breiti (Fig. 93).

Pronotum 1.26-1.35 times as wide as long and 1.20-1.40 times as wide as head, larger (in relation to head) in larger than in smaller specimens; widest in or slightly behind the middle; posterior angles weakly marked; punctation more distinct, more defined, and denser than that of head 

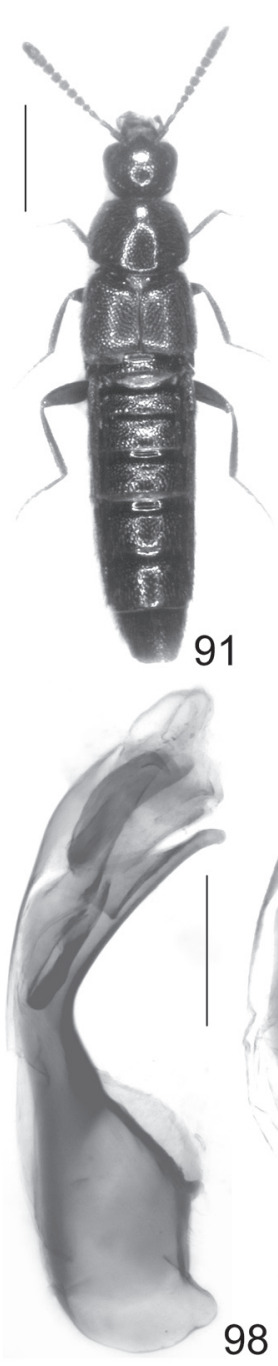

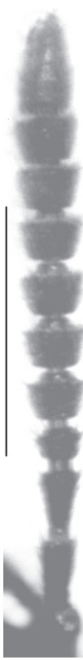

92
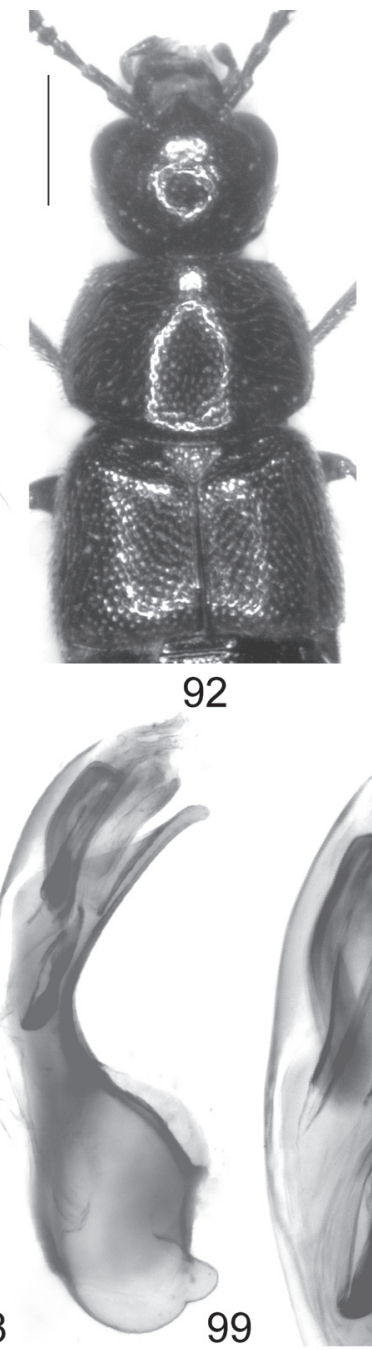

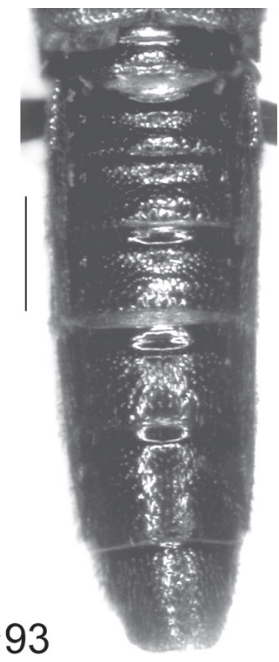

94
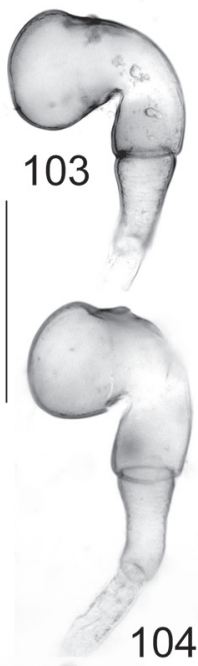

104
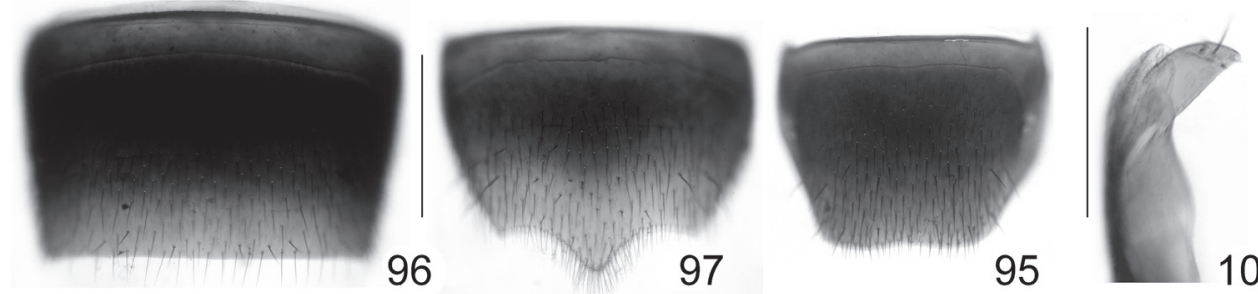

Figs 91-104: Aleochara suslica sp. n.: habitus (91); forebody (92); antennae (93); abdomen (94); male tergite VIII (95); male sternite VII (96); male sternite VIII (97); median lobe of aedeagus in lateral view (98-99); apical portion of median lobe of aedeagus in lateral view (100-101); apical portion of paramere (102); spermatheca (103-104). Scale bars: 91: $1.0 \mathrm{~mm}$; 92-97: $0.5 \mathrm{~mm}$; 98-104: $0.2 \mathrm{~mm}$. 
(Fig. 92); interstices on average approximately as wide as diameter of punctures and without microsculpture.

Elytra 0.75-0.80 times as long as pronotum; posterior margin near posterior angles obliquely truncate, not sinuate (Fig. 92); punctation well-defined, coarser and denser than that of pronotum; interstices narrower than diameter of punctures, without microsculpture. Legs long and slender; metatarsus approximately as long as metatibia or nearly so; metatarsomere I elongate, distinctly longer than the combined length of II and III, almost as long as the combined length of II-IV.

Abdomen: tergites III-V with moderately deep anterior impressions, tergite VI without anterior impression; anterior impressions of tergites III-V with dense and moderately coarse punctation, remainder of tergal surfaces with sparser punctation; interstices of tergites III-VII without microsculpture (Fig. 94); posterior margin of tergite VIII weakly and broadly concave (Fig. 95).

$\sigma^{7}$ : sternite VII with truncate posterior margin, pubescence near posterior margin not conspicuously dense (Fig. 96); posterior margin of sternite VIII produced posteriorly (Fig. 97); median lobe of aedeagus with slender ventral process and internal structures of distinctive shape (Figs 98101); apical lobe of paramere short (Fig. 102).

ㅇ: sternite VIII obtusely pointed posteriorly; spermatheca as in Figs 103-104.

\section{Etymology:}

The name (adjective) is derived from the specific epithet of Spermophilus suslicus, in whose burrows most of the type specimens were found.

\section{Comparative notes:}

Aleochara suslica is distinguished from the species of the A. cuniculorum group by the more slender and more parallel body shape, the darker average coloration (particularly of the legs, also of the elytra), the longer metatarsomere I, the shape and chaetotaxy of the male sternite VII, the completely different morphology of the aedeagus (shape of the ventral process and internal structures, shorter apical lobe of the paramere), the posteriorly more pointed female sternite VIII, and by the shape of the spermatheca. The species is additionally separated from the syntopic $A$. gontarenkoi by the sparser and coarser punctation particularly of the pronotum.

\section{Distribution and bionomics:}

The known distribution of this species is confined to a few localities near Odessa, Ukraine (Map 3). The type specimens were collected from burrows of Spermophilus suslicus and from the nest of a mouse of unknown identity. One specimen was found under a stone.

\section{The species of the Aleochara laevigata group}

Due to the absence of modern revisions of most Palaearctic Aleochara, as well as the long tradition of identifications based on external characters alone, it was not until NikiTsKy et al. (1998) discovered that what had been treated as A. laevigata was in fact a group of closely related species, which can reliably be distinguished only based on the sexual characters.

The species of the A. laevigata group share the following characters: body of small to moderate size; coloration black, elytra often with a (mostly triangular) reddish spot of more or less variable size; whole body without distinct microsculpture and glossy; legs of moderate length, but tarsi long, metatarsus (almost) as long as metatibia; abdomen, including anterior impressions of tergites III-V, coarsely punctate; male sternites III-VII unmodified; male sternite VIII obtusely 
produced posteriorly. Species of this group are characterised particularly by the similarly derived, evidently synapomorphic morphology of the spermatheca, as well as by the similar morphology of the median lobe of the aedeagus and its internal structures (shape of apical sclerotised structures, long flagellum). They are distinguished from the externally similar A. cuniculorum and allied species particularly by the distinctly transverse antennomeres $\mathrm{V}-\mathrm{X}$, the slightly shorter legs, the coarser punctation of the abdomen, the much less pronounced sexual dimorphism of sternite VIII, the different internal structures of the aedeagus, and the different general shape of the spermatheca.

As far as is currently known, all the species of the $A$. laevigata group are coprophilous. Below, seven species are attributed to this group: A. laevigata, A. signata, A. lonae, A. accepta, A. grandeguttata, $A$. brevilaminata, and $A$. falcata. In view of the external similarity and intraspecific variation, only A. laevigata is (re-)described in detail. The descriptions and diagnoses of the remaining species of this group are restricted to distinguishing characters, particularly the genitalia.

\section{Aleochara (Xenochara) laevigata Gyllenhal, 1810 (Figs 105-113)}

Aleochara laevigata GylLenHAL, 1810: 433.

Aleochara apicalis MÉNÉTRIÉs, 1832: 147 f.

Aleochara bisignata ERICHSON, 1837: $357 \mathrm{f}$.

\section{Type material examined:}

Aleochara bisignata: Lectotype ơ: "5572 / bisignata Er. / Europa [curator label] / Hist.-Coll. (Coleoptera), Nr. 5572, Aleochara bisignata Erichson, 1837, Europa - Asia, Zool. Mus. Berlin / ?Syntypus? Aleochara bisignata Erichson, 1837, labelled by MNHUB 2009 / Lectotypus o Aleochara bisignata Erichson, desig. V. Assing 2009 / Aleochara laevigata Gyllenhal, det. V. Assing 2009" (MNHUB). Paralectotypes: 4 exs.: same data as lectotype (MNHUB).

Additional material examined:

Morocco: 1 , Asni env., Iml, 1600 m, 20.VII.1993, leg. Stüben (cWun).

Spain: $10^{\star}$, Andalucía, Granada, Sierra Nevada, near Solynieve, 1850 m, 18.III.1994, leg. Wunderle (cWun).

Germany: Nordrhein-Westfalen: 1 , Euskirchen, Kirchheim, 11.V.1988, leg. Fritz (cWun). Niedersachsen: $1 o^{\star}, 2$ km SE Wolfenbüttel, Öselberg, 150 m, pitfall, IX.1998 (cAss); $1 \sigma^{\star}$, Hannover, Kugelfangtrift, pitfall, VIII.2002, leg. Sprick (cAss); 1 ๙ , N Gifhorn, NSG "Heiliger Hain", Calluna heathland, pitfall, VIII.1987 (cAss); 1 ơ $^{\star}$, same data, but IV.1986 (cAss); 1 오, same data, but IV.1987 (cAss); 1 ơ , E Schladen, Hedeper, Westerberg, pitfall, IV.2001, leg. Schmidt (cAss); 1 ㅇ, same data, but VIII.2001 (cAss); exs., Helmstedt env., Uehrde, Mühlenberg, chicken dung, 10.VIII.1989, leg. Assing (cAss); $20^{\star} \sigma^{\star}, 1$ ㅇ. Helmstedt env., Heeseberg, 31.VIII.1991, leg. Assing (cAss); $10^{\star}$, Heeseberg, sheep dung, 31.V.1991, leg Schmidt (cAss). Sachsen-Anhalt: $1 \sigma^{\star}$, S Halle, Hohenweiden, forest, 30.V.1996, leg. Sprick (cAss); 1 ex. [det. Feldmann], Halle, Gimritz, fallow, pitfall, 4.VIII.1993, leg. Teichmann (cFel); 1 ex., same data, but VI.1993 (cFel); 1 ex., same data, but 11.V.1994 (cFel); 1 ex., same data, but 12.V.1993 (cFel). Thüringen: 1 ㅇ, Jena env., Leutratal, 19.V.1987, leg. Heinig (cSch); 1 ex., Kyffhäuser, Esperstedter Ried, 11.IV.1992, leg. Peschel (cSch); 1 ex., Kyffhäuser, Schlachtberg, 9.V.1989, leg. Peschel (cSch).

Austria: $1 \sigma^{*}$, Burgenland, Neusiedlersee, Kaisereiche, 28.VIII.-9.IX.1988, leg. Melber (cAss); 1 ex., locality not specified (MNHUB).

Greece: 2 ㅇ 우, Levkas, Vouno peak, 1050 m, sifted, 25.IX.1993, leg. Assing (cAss); 1 우, N-Corfu, Zigos env., 24.IX.1994, leg. Wunderle (cWun); 1 ㅇ, Chalkidiki, Kassandra, Pefkohori, beach, human faeces, 21.III.1989, leg. Assing (cAss); 1 \% , Kassandra, Polichoro env., 100 m, donkey dung, 20.III.1989, leg. Assing (cAss); 1 o $^{\star}, 1$ ㅇ, Kassandra, Polichoro, beneath bones, 26.III.1989, leg Assing (cAss); 1 ๆ, Kassandra, 

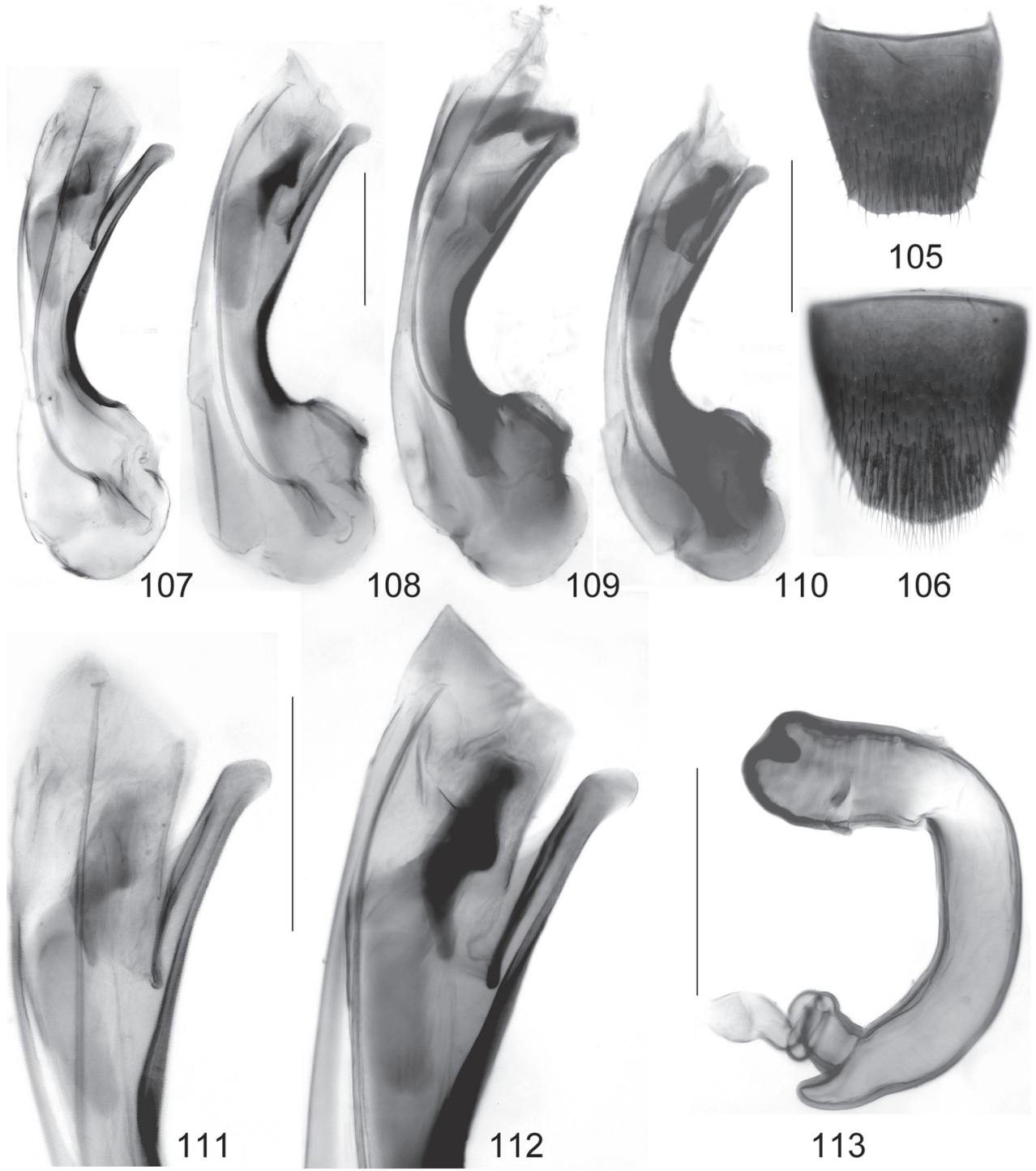

Figs 105-113: Aleochara laevigata Gyllenhal (107, 111: lectotype of A. bisignata Erichson; 108, 112: Germany; 109: S-Spain; 110: E-Turkey): male tergite VIII (105); male sternite VIII (106); median lobe of aedeagus in lateral view (107-110); apical portion of median lobe of aedeagus in lateral view (111-112); spermatheca (113). Scale bars: 105-106: $0.5 \mathrm{~mm}$; 107-113: $0.2 \mathrm{~mm}$.

Polichoro, on bird cast, 20.III.1989, leg. Assing (cAss); 1 o, Pelopónnisos, Patras, Pteri, dung, 7.IV.1986, leg. Assing (cAss); 1 ơ $^{\star}$, Pelopónnisos, Sparta, 28.III.1990, leg. Assing (cAss); 1 ㅇ, Pelopónnisos, 40 km SE Tripoli, E Agios Petros, $37^{\circ} 20^{\prime} \mathrm{N}, 22^{\circ} 35^{\prime} \mathrm{E}, 900$ m, 22.III.1997, leg. Assing (cAss); 1 Pelopónnisos, Korinthía Feneos, $37^{\circ} 56^{\prime} \mathrm{N}, 22^{\circ} 17^{\prime} \mathrm{E}, \mathrm{IV}-\mathrm{VI} .2006$, leg. Miksch (cSch).

Turkey [see also Assıng (2007a)]: Kastamonu/Çankırı: 1 † , Ilgazdağı geçidi, 1900-2200 m, 13.VII.1996, leg. Bayer \& Winkelmann (cSch). Izmir: 1 ex., "Smyrna" (MNHUB). Bitlis: 1 o , 1 †, 16 exs., S Tatvan, 1700-2000 m, 21.V.-18.VI.1973, leg. Schubert (NHMW, cAss); 1 ơ, E lake Van, 1800-2200 m, VI.1971, leg. Schubert (cAss). 


\section{Comment:}

The original description of $A$. laevigata, which is based on an unspecified number of syntypes, is contained in a work on Swedish insects; neither a holotype nor a precise locality are specified (Gyllenhal 1810). The type material was not examined, but since only one species of the A. laevigata group is known from Sweden and this species is described and illustrated by PALM (1972), there is little doubt that the present interpretation of $A$. laevigata is correct. The illustration of the genitalia of $A$. laevigata in Nikitsky et al. (1998) refers to a different species.

The original description of $A$. apicalis is based on an unspecified number of syntypes from "Bakou" (today Baku in Azerbaijan) (MÉNÉTrIÉs 1832). The name has been regarded as a synonym of A. laevigata at least since Bernhauer (1901). An examination of the type material is required to clarify the identity of this name. Repeated requests for a loan have remained unanswered, so that it is uncertain whether the type material still exists.

Like the preceding name, A. bisignata, which was described from Mark Brandenburg (ERICHSON 1837), has been regarded as a junior synonym of $A$. laevigata at least since BERnHauer (1901). In the historical collection of the MNHUB, five specimens that may qualify as syntypes were located. However, since none of them has original locality labels, it is impossible to determine which of them was actually seen by Erichson. Therefore, all of them are regarded as syntypes and the first specimen in the series, a male, is designated as the lectotype. It is conspecific with A. laevigata, so that the long-standing synonymy is confirmed.

Aleochara lonae Gridelli, 1924, which was originally described as a subspecies of A. laevigata (based on type material from Albania) and subsequently regarded as a synonym of that name, refers to a distinct species (see the following section).

\section{Redescription:}

Body length: 3.0-6.0 mm. Usual coloration: blackish; elytra posteriorly with a comparatively small and rather well-delimited reddish spot of triangular shape, this spot usually longer than broad; tarsi pale-brown to dark-brown.

Head approximately as wide as long; punctation rather fine and sparse; median dorsal area usually without punctures; microsculpture absent (traces of microsculpture may be visible on frons); eyes rather large, usually somewhat longer than postocular region in dorsal view. Antenna with antennomere approximately as long as wide or weakly transverse; $\mathrm{V}$ distinctly transverse, distinctly larger and wider than IV; V-X very weakly increasing in width, i.e., X only slightly wider than V; $\mathrm{X}$ approximately 1.5-1.8 times as wide as long; XI slightly longer than the combined length of IX and X.

Pronotum 1.28-1.45 times as wide as long and 1.50-1.60 times as wide as head, widest usually behind the middle; punctation fine and sparse.

Elytra 0.75-0.85 times as long as pronotum; punctation coarser and much denser than that of pronotum. Metatarsus approximately 0.85-0.95 times as long as metatibia; metatarsomere I approximately as long as the combined length of II-IV or nearly so.

Abdomen with segments III-V of subequal width, segments VI-VIII rather weakly tapering; tergites III-V with rather shallow anterior impressions; punctation rather variable, coarse and dense, particularly so in anterior halves of tergites III-VII; posterior margin of tergite VIII crenulate and weakly concave in the middle (Fig. 105).

$\sigma^{*}$ : sternites VI-VII unmodified; posterior margin of sternite VIII weakly produced, very obtusely angled in the middle (Fig. 106); median lobe of aedeagus $0.57-0.75 \mathrm{~mm}$ long, shaped as 
in Figs 107-112, with long and straight, apically characteristically shaped ventral process; internal sac with long flagellum; apical lobe of paramere relatively small, approximately 2.5-3.0 times as long as wide.

† : posterior margin of sternite VIII broadly convex; spermatheca shaped as in Fig. 113, distal part of capsule rather long and slender.

\section{Intraspecific variation:}

According to Bernhauer (1901), Likovský (1974), and other authors, the coloration of the elytra is variable, with the reddish spot occasionally completely obsolete or covering most of the elytra. However, I have seen no such specimens in the material examined. Since A. laevigata has been confounded with various closely related species in the past, it may well be that specimens with completely black or predominantly reddish elytra refer to other species.

\section{Distribution and bionomics:}

According to Smetana (2004), A. laevigata has a trans-Palaearctic distribution, from the Iberian peninsula and Morocco to the Russian Far East and eastern Siberia. In view of the similarity of the species of the $A$. laevigata group, as well as of the fact that the species was previously identified mostly based on external characters, practically all previous records need to be confirmed. The record from Gümüşhane (NE-Turkey) in Assing (2007a) refers to A. grandeguttata (see below).

The species has been found in various kinds of dung, on bird casts, and on carrion. According to Maus et al. (1998), it is a parasitoid of several genera and species of Anthomyiidae and Calliphoridae.

\section{Aleochara (Xenochara) lonae GRIDELLI, 1924, revalidated (Figs 115-118, Map 4)}

Aleochara laevigata lonae GRIDELLI, 1924: 41.

Aleochara (Polychara) gridellii Bernhauer, 1936b: 57; nov. syn.

\section{Type material examined:}

Syntype o: "Albania 1922, Ravasini, Lona / Tomorica Abbas Ali / pr. cornuta Fauv. / laevigata var. Lonae! det. E. Gridelli / Syntypus o Aleochara laevigata lonae Gridelli, rev. V. Assing 2009 / Aleochara lonae Gridelli, det. V. Assing 2009" (MCSNT).

Additional material examined:

Albania: $10^{\star}$, Mali i Gjalicës ["Gjallica"; 4201'N, 20²8'E], 1935, leg. Bischoff (MCSNT).

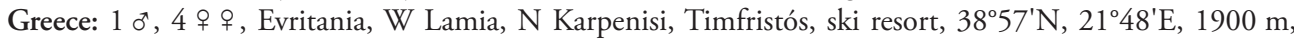
sifted, 14.IV.2000, leg. Assing \& Wunderle (cAss, cWun); 1 ㅇ, N-Pindos, ca. 40 km NNE Konitsa, Oros Arénes, $40^{\circ} 18^{\prime} \mathrm{N}, 20^{\circ} 55^{\prime} \mathrm{E}, 1900 \mathrm{~m}, 27 . \mathrm{V} .2005$, leg Assing (cAss); $10^{\star}$, Pindos, Katara pass, $1690 \mathrm{~m}$, 25.VII.1987, leg. Schuh (cAss).

\section{Comment:}

Aleochara lonae was originally described as a variety of $A$. laevigata, based on two syntypes from "M.te Tomor: Abbas Ali, 2000 m" (Gridelli 1924). According to the original description, one of the type specimens is deposited in the Bernhauer collection, the other in the Ravasini collection. The latter was located in the collections of the MCSNT. Since it is a female, it is not designated as the lectotype. The syntype and the additional material listed above are not conspecific with A. laevigata, but represent a distinct species. 
The details indicated in the original description of A. gridellii Bernhauer 1936, which is based on material from the same locality, probably even from the same sample ("Tomorica (Abas Ali), 1922, Ravasini"), as well as from "Mazedonien: Peristeri, Meschnigg" (Bernhauer 1936), leave no doubt that this name is a synonym of $A$. lonae. In fact, it does not seem unlikely that the syntype of $A$. lonae in the Bernhauer collection is identical to one of the syntypes of $A$. gridellii.

\section{Redescription:}

Body length: $3.0-5.8 \mathrm{~mm}$. External characters as in A. laevigata, but distinguished as follows:

Elytra without reddish spot, either completely black or posteriorly with weakly delimited darkbrown area. Antennae on average shorter; antennomere IV transverse; $\mathrm{X}$ almost twice as wide as long.

$0^{*}$ : sternite VIII as in Fig. 114; median lobe of aedeagus approximately 0.72-0.95 mm long, at base of ventral process with pair of pronounced dark carinae (Figs 115-117).

i : spermatheca smaller, less slender, with longer distal cuticular intrusion, and with distal portion of capsule of different shape (Fig. 118).

\section{Distribution and bionomics:}

Aleochara lonae is currently known only from the southern Balkans (Albania, Macedonia, Greece) (Map 4). All the records are from higher elevations (1690-2000 m).

\section{Aleochara (Xenochara) signata (SAHLBERG, 1876) (Figs 119-123)}

Baryodma signata SAHLBERG, 1876: 75.

Aleochara navicularis Fauvel, 1900: 247; synonymy by Semenov (2003).

Aleochara tertiaria Semenov, 1998: 15 ff.; synonymy by Nikitsky \& Semenov (2001).

Material examined:

Germany: $1 \sigma^{\star}$, Berlin-Lübars, moist slope, 21.IX.1981, leg. Winkelmann (cAss); 1 \%, Lebus/Oder, wheat field, 31.VI.1997, leg. Barndt (cAss).

Mongolia: $1 \delta^{\top}$, Central aimak, SE Somon Bajanzogt, 1600 m, 11.VI.1966, leg. Kaszab [paratype of A. accepta, see type material of $A$. accepta].

\section{Comment:}

The original description of $A$. signata is based on an unspecified number of syntypes from "Wiborgs län" (today St. Petersburg region) and "Åbo" in southern Finland (SAHLBERG 1876). These localities are not accounted for by SMETANA (2004). The type material was studied and a lectotype was designated by Semenov in Nikitsky \& Semenov (2001), who also placed $A$. tertiaria in synonymy with $A$. signata.

Aleochara navicularis, whose original description is based on a single specimen from "Irkoutsk" (Fauvel 1900), was recently synonymised with $A$. signata by Semenov (2003), who also designated a lectotype for $A$. navicularis. For illustrations of the genitalia and descriptive details see Nikitsky et al. (1998). Only recently, ÁDÁm (2008) synonymised also A. accepta Likovský with A. signata, but this synonymy is incorrect (see the following section).

\section{Redescription:}

Body length: 4.5-5.5 mm, according to Nikitsky et al. (1998). External characters as in A. laevigata, but distinguished as follows: 


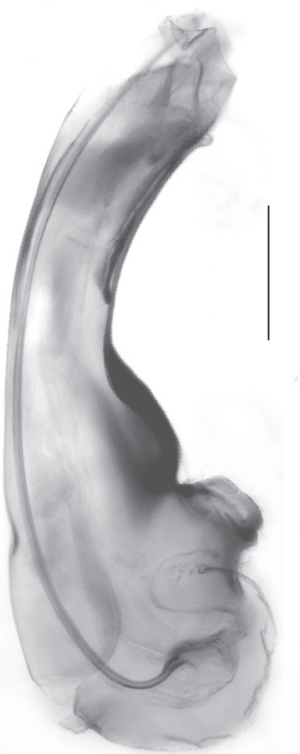

115

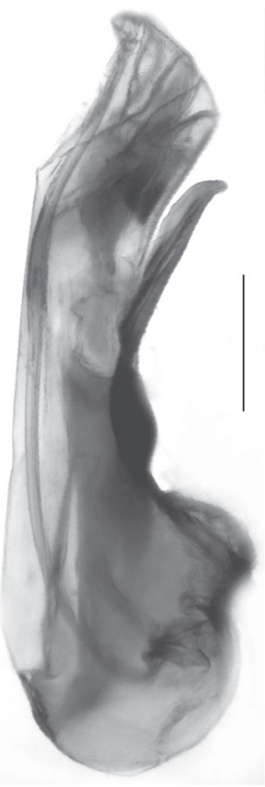

119

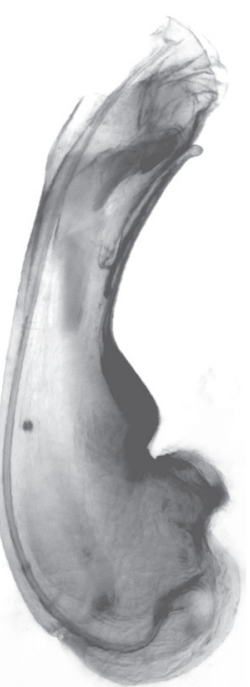

116

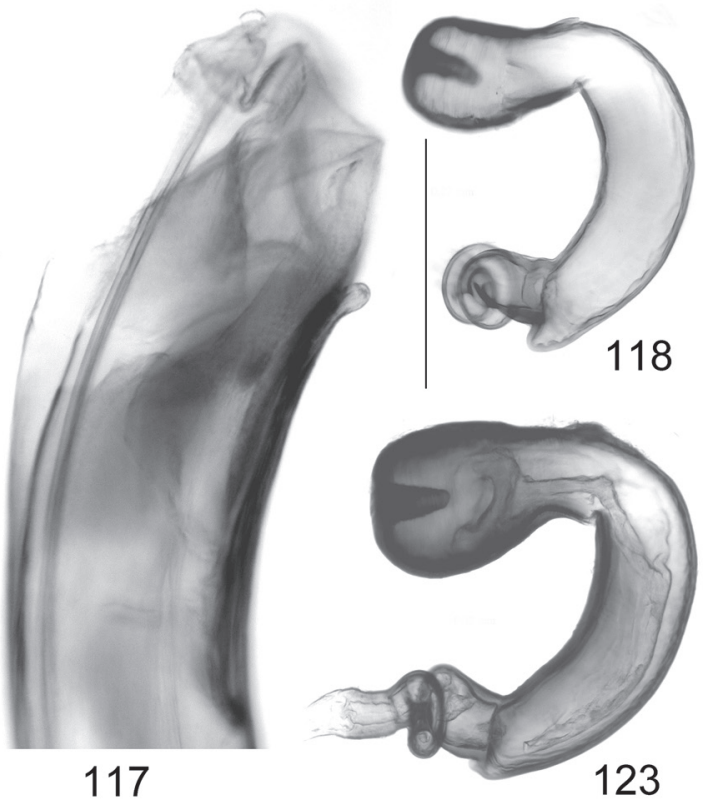

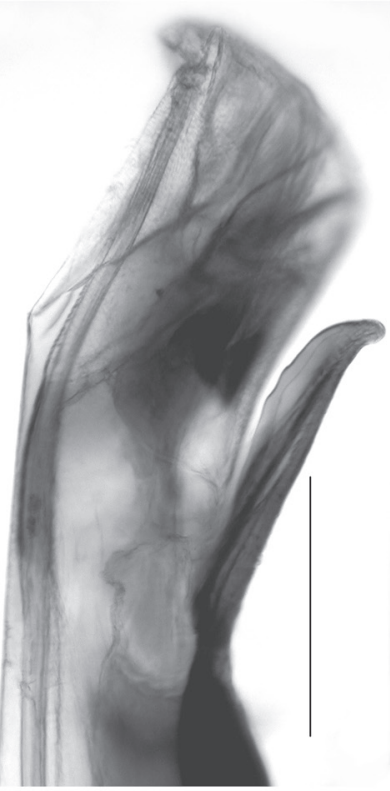

120

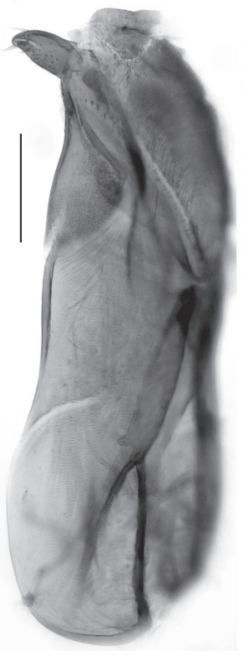

121

Figs 114-123: Aleochara lonae Gridelli (114-118; 115, 117: Albania; 114, 116: Greece) and A. signata (SAHLBerG) (119-123): male tergite VIII (114); median lobe of aedeagus in lateral view (115-116, 119); apical portion of median lobe of aedeagus in lateral view $(117,120)$; spermatheca $(118,123)$; paramere (121); apical lobe of paramere (122). Scale bars: 114: $0.5 \mathrm{~mm}$; 115-121, 123: $0.2 \mathrm{~mm}$; 122: $0.1 \mathrm{~mm}$. 
Coloration paler: elytra extensively reddish, usually with the anterior and lateral margins, as well as the suture more or less distinctly darkened. Metatarsus clearly (approximately $0.8 \mathrm{x}$ ) shorter than metatibia.

$\sigma^{7}$ : median lobe of aedeagus large, approximately 0.85-0.90 $\mathrm{mm}$ long, somewhat resembling that of $A$. lonae, with pronounced carinae at base of ventral process (Figs 119-120); apical lobe of paramere small and only approximately twice as long as broad (Figs 121-122).

i: spermatheca distinctly larger and less slender than that of $A$. laevigata, and with distal portion of capsule of different shape (Fig. 123).

\section{Distribution:}

The distribution of this species is insufficiently known, with scattered records reported from eastern Scandinavia, from the northern and central parts of European Russia, eastern Siberia, Mongolia, and Germany (Assing \& Schülke 2001; Semenov 1998; Sahlberg 1876; Smetana 2004).

\section{Aleochara (Xenochara) accepta LıKоvsKर́, 1972; revalidated (Figs 124-126)}

Aleochara (Polychara) accepta Likovskx́, 1972: 162 f.

\section{Type material examined:}

Holotype $0^{\star}$ : "Mongolia, Central aimak, cca $20 \mathrm{~km} \mathrm{~W}$ von Ulan-Baator, $1600 \mathrm{~m}$, Exp. Dr. Z. Kaszab, 1966 / Nr. 526, 17.VI.1966 / Holotypus 1970 Aleochara accepta Likovsky [curator label] / Holotypus Aleochara accepta m., det. Z. Likovský 1970 / Holotypus / Aleochara signata (J. Sahlb.), det.: Ádám, 2007 / Aleochara accepta Likovský, det. V. Assing 2009" (HNHM). Paratypes: $1 \mathrm{o}^{\mathrm{T}}$, "Mongolia, Central aimak, Tosgoni ovoo, $10 \mathrm{~km} \mathrm{~N}$ von Ulan-Baator, 17001900 m, Exp. Dr. Z. Kaszab, 1967 / Nr. 926a, 23.-24.VII.1967 / Paratypus 1970 Aleochara accepta Likovsky [curator label] / Paratypus Aleochara accepta m., det. Z. Likovský 1970 / Paratypus / Aleochara accepta Lik., V.B. Semenov det. 1998 / Aleochara accepta Likovský, det. V. Assing 2009" (HNHM); 1 o", "Mongolia, Central aimak, Ulan-Baator, Nucht im Bogdo ul, 18802000 m, Exp. Dr. Z. Kaszab, 1966 / Nr. 506, 9.VI.1966 / Paratypus 1970 Aleochara accepta Likovsky [curator label] / Paratypus Aleochara accepta m., det. Z. Likovský 1970 / Aleochara

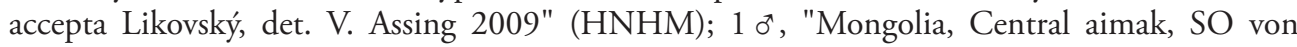
Somon Bajanzogt, 1600 m, Exp. Dr. Z. Kaszab, 1966 / Nr. 920b, 11.VI.1966 / Paratypus 1970 Aleochara accepta Likovsky [curator label] / Paratypus Aleochara accepta m., det. Z. Likovský 1970 / Paratypus / Aleochara tertiaria mihi (non typus!), V. B. Semenov det. 1998 / Aleochara signata (Sahlberg), det. V. Assing 2009" (HNHM).

\section{Comment:}

The species was originally described from Mongolia based on a holotype from "Central aimak: cca $20 \mathrm{~km} \mathrm{~W}$ von Ulan-Baator, $1600 \mathrm{~m}$ " and 25 paratypes from various localities (LikovskÝ 1972). For illustrations of the genitalia and descriptive details see Nikitsky et al. (1998). The synonymy of $A$. accepta with $A$. signata proposed by ÁDÁm (2008) is erroneous. The holotype and two examined paratypes represent a distinct species and only one of the examined paratypes is conspecific with $A$. signata.

\section{Redescription:}

Body length: $3.0-4.7 \mathrm{~mm}$, according to Nikitsky et al. (1998). External characters as in A. laevigata, but distinguished as follows: 
Antennae shorter; antennomeres V-X more transverse, approximately twice as wide as long. Reddish spot on elytra more extensive and weakly delimited.

$0^{*}$ : median lobe of aedeagus small, 0.53-0.62 mm long, of similar general morphology as in A. laevigata, but ventral process and apical internal structures of completely different shape in lateral view, apical internal structures very weakly sclerotised (Figs 104-106).

\section{Distribution and bionomics:}

The known distribution ranges from Belarus and Ukraine to eastern Siberia and the Russian Far East (Nikitsky et al. 1998; SMetana 2004).

\section{Aleochara (Xenochara) falcata nov. sp. (Figs 127-128)}

\section{Type material:}

Holotype $0^{\top}$ : "Rußland: Baschkirien, Maginsk, Pavlovsker Stausee, Birken-Kiefern-Wald, BF, 27.06.1989, Schnitter / Holotypus o Aleochara falcata sp. n., det. V. Assing 2009" (cAss). Paratypes: $1 \sigma^{-1}$ : same data as holotype (cSch); $10^{*}$ : "Russia. centr. RSFSR, Gebiet Tul, 301860Jefremow, 28.V.1986, leg. A. Pütz" (cWun).

\section{Description:}

External and secondary sexual characters similar to those of A. laevigata; distinguished only as follows:
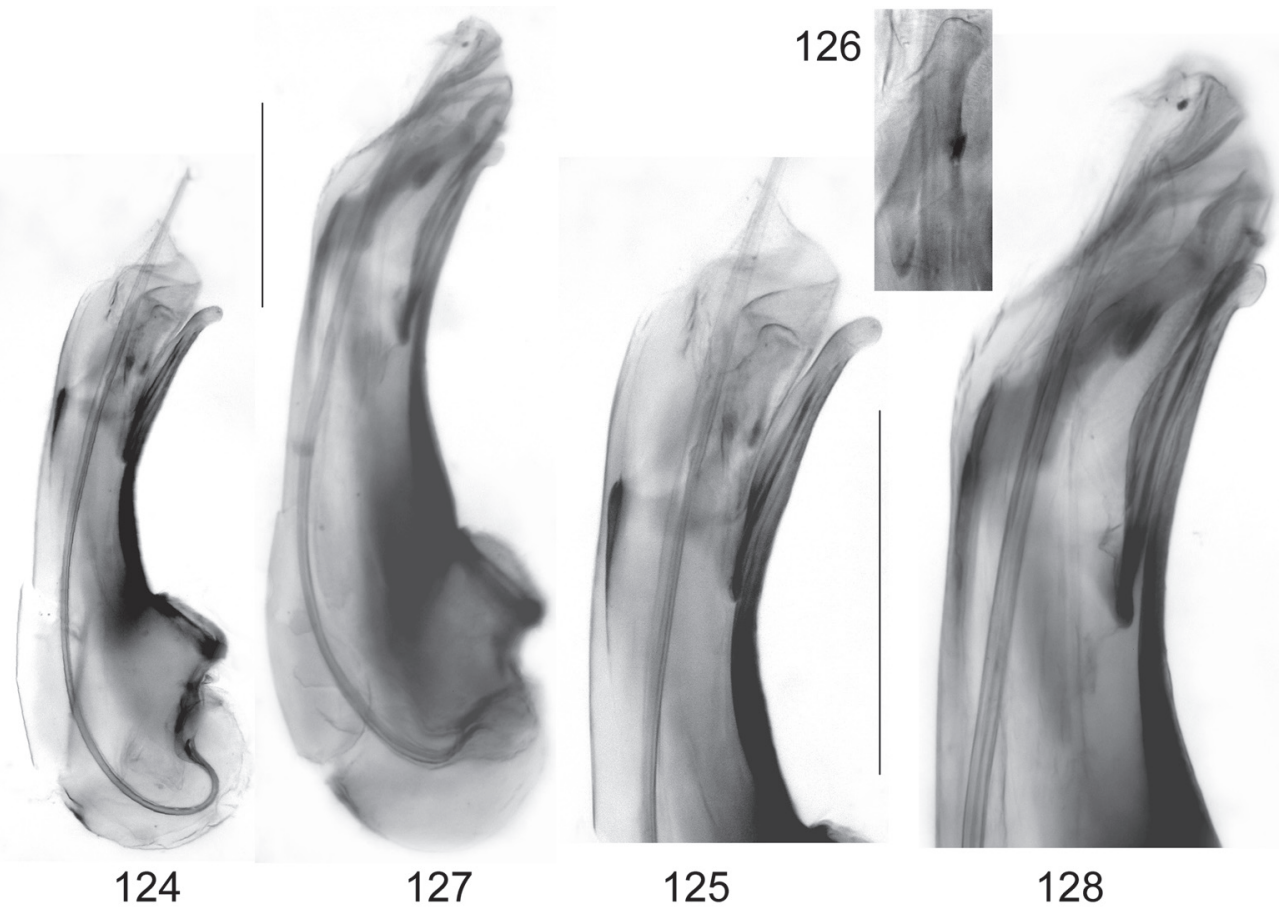

Figs 124-128: Aleochara accepta LikovskÝ, paratype (124-126) and A. falcata sp. n., holotype (127-128): median lobe of aedeagus in lateral view $(124,127)$; apical portion of median lobe of aedeagus in lateral view $(125,128)$; apical internal structure of aedeagus (126). Scale bars: $0.2 \mathrm{~mm}$. 
Antenna distinctly longer and more slender; antennomere IV as long as wide or weakly transverse; antennomeres $\mathrm{V}$-X weakly transverse, at most 1.5 times as wide as long.

$\sigma^{7}$ : median lobe of aedeagus with weakly arcuate and apically more slender ventral process in lateral view; apical internal structures slender (Figs 107-108).

i: unknown.

\section{Etymology:}

The name (Latin, adjective: shaped like a sickle) refers to the shape of the apical internal structures of the aedeagus.

\section{Comparative notes:}

Aleochara falcata is reliably distinguished from other species of the A. laevigata group by the slender antennae and by the morphology of the median lobe of the aedeagus. From A. accepta, whose aedeagus is of somewhat similar shape, it is separated also by larger average size, more slender and longer antennae, the more delimited and less extensive reddish spot on the elytra, the larger median lobe of the aedeagus, the shorter flagellum in the internal sac of the aedeagus, the differently shaped and more strongly sclerotised apical internal structures, and the differently shaped apex of the ventral process of the aedeagus.

\section{Distribution and bionomics:}

The species is currently known only from two localities in Russia. Two of the type specimens were collected with pitfall traps in a mixed pine and birch forest.

\section{Aleochara (Xenochara) grandeguttata nov. sp. (Figs 129-134, Map 4)}

\section{Type material:}

Holotype $0^{\star}:$ :TR - Burdur, $1020 \mathrm{~m}, 11$, NW Çaydir, deciduous wood in arable land, $37^{\circ} 10^{\prime} 47 \mathrm{~N}$, $29^{\circ} 38^{\prime} 43 \mathrm{E}$, 9.VII.2002, V. Assing / Holotypus ơ Aleochara grandeguttata sp. n., det. V. Assing 2009" (cAss). Paratypes: 1 o': "TR - Gümüşhane, ca. 50 km SW Trabzon, 2500 m, E Zigana Geç., ca. $40^{\circ} 37^{\prime} \mathrm{N}, 39^{\circ} 26^{\prime} \mathrm{E}, 11 . \mathrm{VI} .1998$, Solodovnikov" (cAss); 2 o $^{\star}$ o $^{\star}, 5$ ㅇ 우: "TR - [26a] - Sinop,

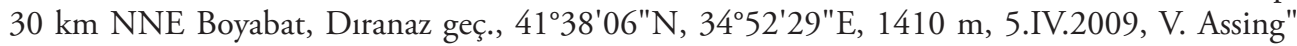
(cAss); $1 \sigma^{\star}$, same data, but leg. Wunderle (cWun); 6 o $^{\star}, 3$ ㅇ ㅇ , 4 exs.: "Turkey, Cildir Göl, 1800 m, VI.1977, leg. F. Schubert" (NHMW, cAss); $20^{\star \top} \sigma^{\star}$ : "Akkus, Anat. bor., leg. F. Schubert / 6/72 [overleaf]" (NHMW, cAss); 1 : "Petrowitz-Ressl, Reise nach Kleinasien 1960 / Umg. Akschehir, 16.5.1960 / Sultan-Dagh, in Detritus u. unter Steinen" (NHMW); $10^{*}:$ same data, but

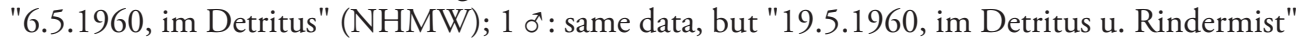
(NHMW); $10^{\star}$ : same data, but "4.5.1960, im Detritus" (cAss); 1 9: "TR [23] - Samsun, $21 \mathrm{~km}$ NNE Havza, 950 m, 41 $08^{\prime} 47^{\prime \prime N}, 35^{\circ} 45^{\prime} 15^{\prime \prime E}$, Quercus-Carpinus for., 19.VII.2008, Schülke" (cSch); 1 ㅇ: "Türkei - 1989, leg. Schönmann et Schillhammer / Prov. Erzurum, 9.6., Umg. Oltu" (NHMW); 2 : "Türkei - 1987, leg. Schönmann et Schillhammer / Prov. 60 e Tatvan, 8.6.1987" (NHMW); 1 ex.: "Palandöken Dag, 2300 m, Erzurum / 21.6.1973, leg. F. Schubert" (NHMW); 1 ex.: "Tatvan, Asm. or., 1900 m, 20.5.69, leg. F. Schubert" (NHMW); 5 exs.: "Tatvan, 1800 m, Asm., leg. F. Schubert / 6/71 [overleaf]" (NHMW, cAss); 1 ex.: "o / Abkkari

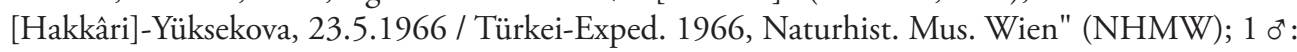
"Borcka, Asm. NO., 1500 m, leg. F. Schubert / 6/72 [overleaf]" (NHMW); 1 o , 2 exs.: "Ungarn, Balaton bei Szigliget, 22.4.1992, Peschel" (cSch, cAss); 1 o $^{\star}$ : "Armenia, Covagjuch, 2.6.88, lgt. S. Bečváŕ" (cSch). 


\section{Comment:}

It appears unlikely that $A$. apicalis MÉNÉTriés, 1832 refers to this species. According to the original description of $A$. apicalis, the reddish elytral spot is situated "à l'extrémité, vers l'angle intérieur" (MÉNÉTRIÉs 1832), which fits better to A. laevigata than to $A$. grandeguttata.

The fact that $A$. laevigata, too, is present in Turkey and was occasionally found in the same localities as A. grandeguttata suggests that the observed differences are an expression of inter- rather intraspecific (clinal) variation.

\section{Description:}

Body length: $3.5-5.5 \mathrm{~mm}$. External characters as in A. laevigata, but distinguished as follows:

Reddish spot on elytra larger, usually occupying most of the posterior surface of the elytra and leaving only the lateral margins blackish.

$\sigma^{*}$ : median lobe of aedeagus, $0.70-0.88 \mathrm{~mm}$ long, strongly arched, almost angular in lateral view, at base of ventral process with more pronounced and more strongly sclerotised (darker) carinae, apex of ventral process more slender and of different shape; crista proximalis larger; apical sclerotised internal structures differently shaped, more slender, and longer (Figs 129-132).

9 : spermatheca with proximal portion of capsule longer and proximally without distinct toothlike projection; apical cuticular intrusion longer (Figs 133-134).

\section{Etymology:}

The name (Latin, adjective: large-spotted) refers to the only external character distinguishing this species from $A$. laevigata, the large reddish spots on the elytra.

\section{Distribution and bionomics:}

The type specimens were collected in various parts (east, west, north, and south) of Turkey and Armenia (Map 4) at lower and at higher elevations. According to their labels, three of the paratypes were collected in Hungary. However, in view of the fact that this record would be at a considerable distance from other confirmed localities of $A$. grandeguttata, the presence of the species in Hungary requires confirmation; the possibility that these specimens may have been mislabelled cannot be ruled out completely. There is little doubt that the species is more widespread than presently known. Some of the specimens were sifted from forest litter, but these records are probably accidental. Like other species of the A. laevigata group, A. grandeguttata is most likely coprophilous.

\section{Aleochara (Xenochara) brevilaminata nov. sp. (Figs 135-142, Map 4)}

\section{Type material:}

Holotype o*: "Kyrgyzstan/Naryn, Moldo-Too Ch., Suulu-Kurtka river, 30.-31.VII.2006, 41 38'20"N, 7502'10"E, 2350 m, l. L. Schmidt / Holotypus o' Aleochara brevilaminata sp. n., det. V. Assing 2009" (cAss). Paratypes: 10 exs.: same data as holotype (cAss); $10^{\star}:$ "Kyrgyzstan/ Talass, Kirgizskij A., Terek-Sai valley, 18.-20.VII.2006, 42³4'17"N, 7242'49"E, 1850 m, leg. L. Schmidt" (cAss); $10^{7}$ : "Kyrgyzstan/Dshai-Abad, Chatkal-Valley, Chatkal river, 23.VII.2006, 4139'42"N, 7044'48"E, 1400 m, leg. L. Schmidt" (cAss); 1 ơ, 2 우 ㅇ : "Kyrgyzstan/Batken, KyzylKija, 15.IV.2007, N40¹5'46", E7208'35", 1000 m, leg. L. Schmidt" (cAss); 1 o: "Kyrgyzstan/ Issyk-Kul, Tort-Kul, 11.IV.2007, N4206'50", E76 ${ }^{\circ} 55^{\prime} 54^{\prime \prime}, 1760$ m, 1. L. Schmidt" (cAss); 1 +, "Kirghizia - $1830 \mathrm{~m}$, Tschatkalski Chrebet, Tschatkal valley near, Karysch-Kyja, 41 $49^{\prime} 58 \mathrm{~N}$, 7111'41E, 28.VII.1998, leg. Müller-Motzfeld" (cAss); 2 우: "Kyrgyztan [sic], Ferghansky 

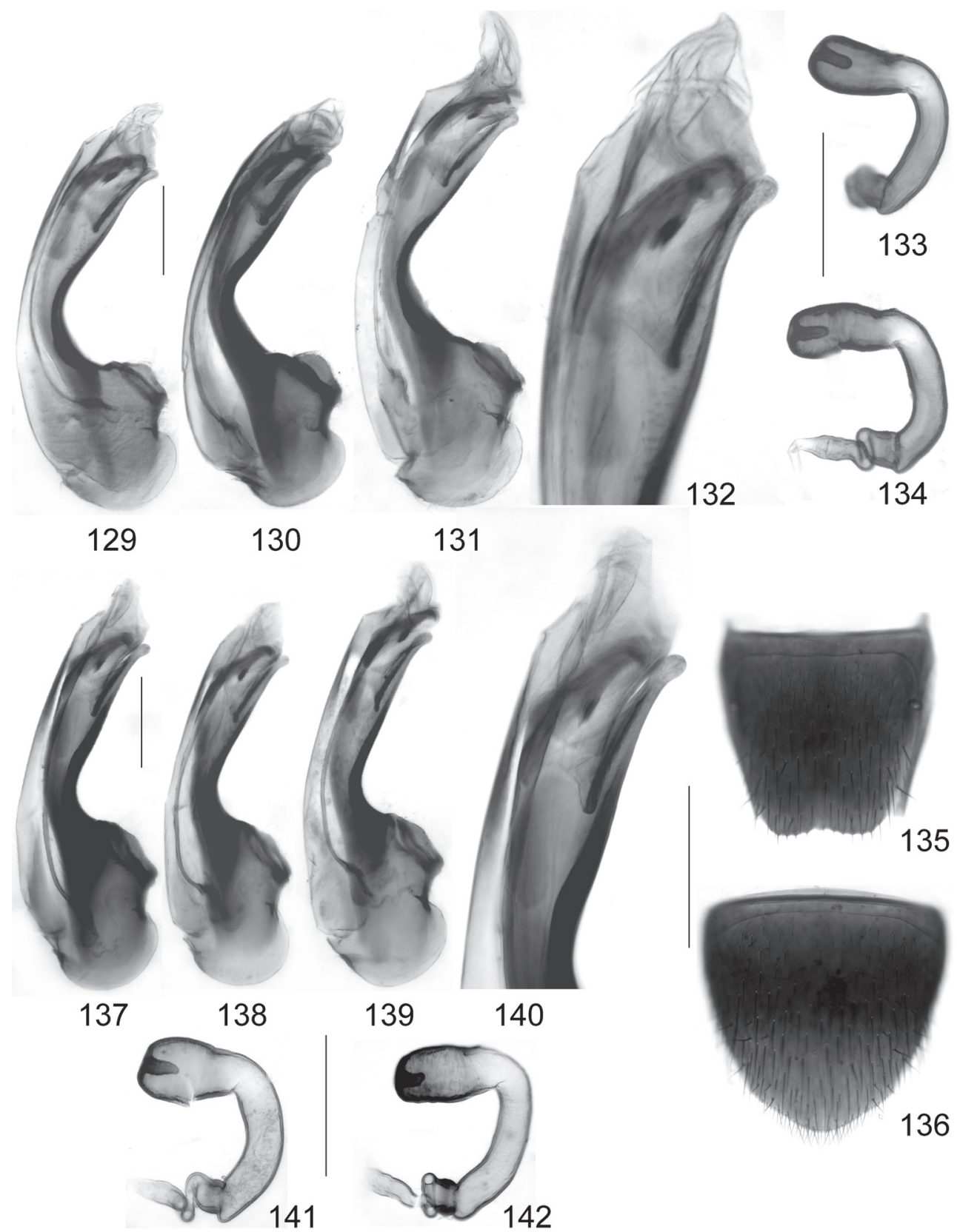

Figs 129-142: Aleochara grandeguttata sp. n. (129-134) and A. brevilaminata sp. n. (135-142): median lobe of aedeagus in lateral view (129-131, 137-139) of holotype (129) and paratypes from Turkey (130-131), Kazakhstan (137), Kyrgyzstan (138), and Tajikistan (139); apical portion of median lobe of aedeagus in lateral view (132, 140); male tergite VIII (135); male sternite VIII (136); spermatheca (133-134, 141-142). Scale bars: 135-136: $0.5 \mathrm{~mm}$; 129-134, 137-142: $0.2 \mathrm{~mm}$. 


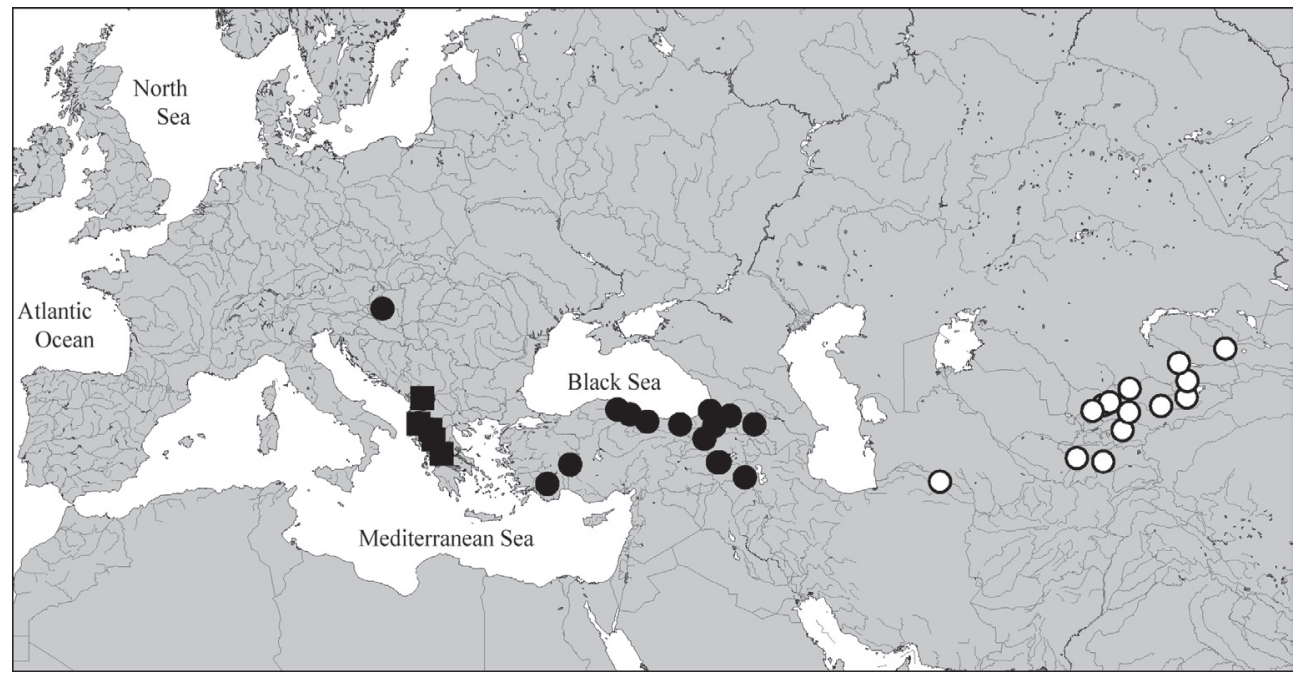

Map 4: Distributions of species of the Aleochara laevigata group in the Western Palaearctic region and Middle Asia, based on revised records: A. lonae Gridelli (squares), A. grandeguttata sp. n. (filled circles) and A. brevilaminata sp. n. (open circles).

Alatau, Toskool Ata, 1.VIII.2002" (cSch); 2 ㅇ ㅇ: "Uzbekistan, E Tashkent, Chatkalskyi range, Shikaftar, 26.VII.2001" (cSch); 1 o $^{\star}, 10$ exs.: "Asia centr., Tadhikist., Pamir Alai, Hissar Mts., Adshuk Cleft near Warsob, 1200 m, 1.-3.VII.1990, leg. Schülke \& Wrase" (cSch, cAss); 2 o o , 1 ex.: "S-Kazakhstan, 1300 m, E Zailyiskyi-Alatau, Belshabdar river, 25.-27.VI.2002, Putchkov" (cAss); 1 o $^{\star}, 1$ \%: "Kasachstan (SO), Dzungarskij Alatau, Mt. Toksanbaj, Koksu, Koksu river, 3.07.1993, leg. R. Predel" (cSch, cAss); 1 ․ "06.07.1993, 5 km South of Akshij, riv. Kurty, SOKazakhstan, leg. R. Predel" (cSch); $1 \sigma^{\star}$ : "Tajikistan: Kalaykhumbskiy Rayon, Viskharvi [probably near Qal'aikhum, $\left.38^{\circ} 28^{\prime} \mathrm{N}, 70^{\circ} 45^{\prime} \mathrm{E}\right]$, Ubaginara cleft, in dung, 1800-200 m, V. Mikhailov, 13.6.1981 [tansliteration from Cyrillic]" (cSch); $10^{*}, 1$ : : Tajikistan: Kalaykhumbskiy Rayon, Viskharvi cleft [probably near Qal'aikhum, 38²8'N, 70 $45^{\prime} \mathrm{E}$ ], subalp., Viskharvi-Bolo peak, V. Mikhailov, 12.6.1981" (cSch, cAss); $10^{\star}, 1$ ex.: "Iran, Razavi-Khorasan Prov., Emam QoliKapkan rd: 17 km O Emam Qoli: Aghmazar, 1850 m (Koppe Dag), N 37²19'16" E 05841'13", 31.05.2006, lg. Frisch \& Serri" (cAss); 1 : "Iran, Kermanshah Province, Ghara Tappeh, 1950 m, N 344' 49" E 04751'12", 23.06.2004, leg. J. Frisch" (MNHUB).

\section{Description:}

Body length: $3.5-5.2 \mathrm{~mm}$. External characters as in A. laevigata, but distinguished as follows:

Reddish spot on elytra broader, broader than long and occupying more than half of posterior margin, and on average slightly larger. Antennae with antennomeres V-X slightly more transverse, approximately twice as wide as long.

$\mathrm{O}^{\star}$ : tergite VIII and sternite VIII as in Figs 135-136; median lobe of aedeagus, 0.65-0.80 mm long, with ventral process shorter in relation to basal capsule, apex of ventral process more slender and of different shape in lateral view; apical sclerotised internal structures more slender and longer (Figs 137-140).

ㅇ: spermatheca somewhat smaller, proximal portion of capsule proximally with less pronounced tooth-like projection; apical cuticular intrusion longer (Figs 141-142). 


\section{Etymology:}

The name (Latin, adjective: with short lamen) refers to the relatively short ventral process of the aedeagus.

\section{Distribution and bionomics:}

The known distribution includes Kyrgyzstan, Tajikistan, Uzbekistan, southern Kazakhstan, and Iran (Map 4). The type specimens were collected at altitudes of 1000-2350 m, many of them from dung.

\section{The species of the Aleochara maculata group}

Species of the $A$. maculata group usually live in mountain habitats, at intermediate to high elevations, and are apparently coprophilous. They are characterised particularly by the derived morphology of the median lobe of the aedeagus, i.e., the conspicuously arched, long, slender, and apically very acute ventral process, as well as the shape of the apical sclerotised structures in the internal sac. In addition, they share the following characters: body of moderate to rather large size; coloration blackish with the elytra often partly or completely reddish; antennae moderately slender, with the preapical antennomeres distinctly less than twice as wide as long; punctation of forebody rather fine, that of abdomen relatively coarse and not very dense (except for the densely punctate anterior impressions of tergites III-V); legs moderately slender, with the metatarsi somewhat shorter than the metatibiae; dimorphism of sternite VIII pronounced; spermatheca of rather uniform shape.

\section{Aleochara (Xenochara) maculata BRISOUT DE BARNeVILLE, 1863 (Figs 143-147, Map 5)}

Aleochara maculata Brisout DE BARNeville, 1863: 18.

Aleochara maculata weiratheri BERNHAUER, 1940: 1047.

Material examined:

Spain: 1 o , Galicia, Orense, Peña Trevinca, 1800 m, 3.VI.1995, leg. Starke (cAss); 4 exs. [det. Tronquet], Cantabria, Santander, Pico de Tres Mares, 2000-2100 m, 31.V.1990, leg. Tronquet (cTro); 1 q [det. Feldmann], Asturias, Picos de Europa, Andara, 1900 m, snowfield, 27.V.1999, leg. Aßmann (cFel); 1 o $^{\star}$, Aragón, Huesca, Valle de Astun, 1900 m, 26.VI.2003, leg. Valcárcel (cAss); 1 ex. [det. Tronquet], Cataluña, Lérida, Sierra de Port del Comte, Pla de Bassiès, 2000 m, 20.IV.1999, leg. Tronquet (cTro); 1 ơ , CastillaLeón, León, Peña Ubiña, above Puerto Ventana, 1950 m, 3.VI.1998, leg. Hetzel (cAss); 1 ơ, 3 우 ㅇ, León, Sierra del Cabrera, Viscodillo, 2050 m, 23.V.1999, leg. Feldmann (cAss, cFel); 1 đ, Castilla-León, Burgos, Sierra de Neila, road from El Collado to Quintamar, 27.V.1994, leg. Schülke \& Grünberg (cSch); 1 o, Castilla-León, Ávila, Sierra de Gredos, 1700 m, V.1992, leg. Poot (cWun).

France: 1 ex., Pyrénées-Atlantiques, Pic d'Orhy, VI.1990, leg. Poot (cWun); 1 9 , Pyrénées-Atlantiques, Col de la Pierre St. Martin, Murlong, 4257'N, 045'W, 1800-2000 m, 8.VI.1998, leg. Lompe (cAss); 2 exs. [det. Tronquet], Hautes-Pyrénées, Aragnouet, Val d'Estarragne, 2300-2450 m, 27.VI.1969, leg. Tronquet (cTro); 1 ex. [det. Tronquet], Pyrénées-Orientales, Prats-de-Mollo, VII.1975, leg. Tronquet (cTro); 1 ex. [det. Tronquet], Pyrénées-Orientales, Canigou mt., Pla Guilhem, 2200 m, snowfield, 1.VI.1998, leg. Tronquet (cTro); 1 ex. [det. Tronquet], Canigou mt., Ras de Prat de Cabrera, $1650 \mathrm{~m}$, 9.V.2001, leg. Tronquet (cTro); 1 ex. [det. Tronquet], Ariège, Col de Pailhières, 2000 m, 4.VII.1970, leg. Tronquet (cTro). 
Italy: 1 ex., Piemonte, Monte Saccarello (CN), 13.VI.1998, leg. Diotti (cAss); 1 ơ $^{\star}$, Alpi Cozie, valley W Maddalena, 1800 m, 30.VI.1997, leg. Feldmann (cFel); $2 \sigma^{\star} \sigma^{\star}$, Lazio, SE Terni, Monti Reatini, Passo Terminillo, 1900 m, near snow, 3.VI.2000, leg. Wunderle (cWun, cAss); 1 o $^{\star}$, Lazio, M. Terminillo, Campo Forogna (RI), 11.V.1998, leg. Angelini (cAss).

Austria: 1 ㅇ, Wien, Strebersdorf (NHMW); 2 exs., Wien env., leg. Breit (NHMW); 1 \% , Steiermark, Stuhleck, leg. Woerz (NHMW); 1 ex., Steiermark, Schöckl Alpe, leg. Strupi (NHMW).

Czech Republic: 1 ex., "Prag", leg. Skalitzky (NHMW).

Romania: 1 ex., Lotrului Mts., Prejba ["Presbe"], leg. Gassner (NHMW).

Bosnia-Herzegovina: $1 \sigma^{\star}$, Vlašic planina, 600-1700 m, car-net, 5.V.1990, leg. Wunderle (cAss); $1 \delta^{\star}$, Treskavica (NHMW).

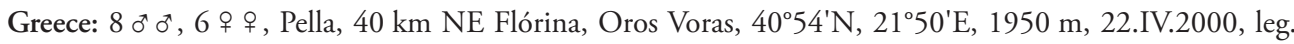

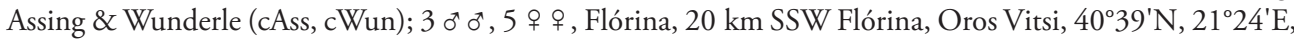
$1870 \mathrm{~m}$, snowfield, 22.V.2005, leg. Assing (cAss); 1 ex. [det. Feldmann], Ipiros, Peristeri, Anthohori, $39^{\circ} 41^{\prime} \mathrm{N}, 21^{\circ} 07^{\prime} \mathrm{E}, 1700-2200 \mathrm{~m}, 4 . V I .2000$, leg. Marggi (cFel); 3 o $0^{\star}$, Makedhonía, Dráma, Falakró, above ski resort, ca. $1800 \mathrm{~m}$, near snow, 26.V.1999, leg. Assing \& Wunderle (cAss, cWun); 2 우 ㅇ, Fokis, $45 \mathrm{~km}$ SSW Lamia, Oros Giona, 38 $40^{\prime} \mathrm{N} ; 22^{\circ} 20^{\prime} \mathrm{E}, 1700 \mathrm{~m}, 17 . I V .2000$, leg. Assing (cAss); 1 ex. [det. Feldmann],

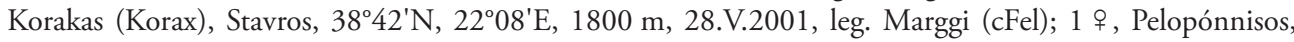
Aroania (Chelmos), $2000 \mathrm{~m}$, snow field, 6.VI.1996, leg. Wunderle (cWun); 2 exs. [det. Feldmann], Pelopónnisos, Taygetos, Profitis Ilias, 36 $57^{\prime} \mathrm{N}, 22^{\circ} 21^{\prime} \mathrm{E}, 2250 \mathrm{~m}, 16 . \mathrm{V} .2007$, leg. Starke (cFel).

Turkey: $1 \mathrm{o}^{\star}$, Gümüşhane, ca. $50 \mathrm{~km} \mathrm{SW}$ Trabzon, $10 \mathrm{~km} \mathrm{~S}$ Dikkaya, ca. $40^{\circ} 36^{\prime} \mathrm{N}, 39^{\circ} 29^{\prime} \mathrm{E}, 2000 \mathrm{~m}$, 9.VI.1998, leg. Solodovnikov (cAss); $10^{\star}$, Rize, ca. $30 \mathrm{~km} \mathrm{SW} \mathrm{Hopa,} \mathrm{Çağlayan} \mathrm{D.} \mathrm{river} \mathrm{valley,} \mathrm{ca.} 41^{\circ} 09^{\prime} \mathrm{N}$, 412'ㄹ, 1800-1900 m, 26.VI.1998, leg. Solodovnikov (cAss); 2 ơ $^{\star}$, Erzurum, $35-40$ km NW Tortum, Mescit Dağları, ca. 40³0'N, 41ํ1'E, 2600 m, 19.VI.1998, leg. Solodovnikov (cAss).

\section{Comment:}

The original description of $A$. maculata is based on an unspecified number of syntypes from "Paris. Vernet. (Pyrénées-orientales.)" (Brisout de BARneville 1863). The localities suggest that the type series may not be conspecific; the species, as interpreted today, is most unlikely to occur in the environs of Paris, since higher mountains are absent in this region. A loan of the type material was requested, but, according to the curator in charge, it is currently inaccessible (TAGHAVIAN, pers. comm.). However, specimens from the vicinity of one of the type localities (Vernet) were seen, so that there is little doubt that the present interpretation is correct. BERnHAUER (1940) described $A$. weiratheri from an unknown number of syntypes collected in "Bosnien: Vitorog Planina im Osten von Glamoc", originally as a variety of $A$. maculata. The name is currently listed as a synonym of that species (SMETANa 2004). The illustrations of the aedeagus figured by Likovský (1974), PaLm (1972), and Welch (1997) are somewhat misleading.

\section{Redescription:}

Body length: 5.0-8.0 mm. Coloration: body blackish; elytra posteriorly with a rather small, dark reddish spot of more or less triangular shape near sutural angle; occasionally, this spot may be more or less reduced, sometimes leaving only the posterior margin of the elytra dark reddish; tarsi reddish to reddish-brown.

Head approximately as wide as long or weakly transverse; punctation rather fine and sparse; interstices with very fine micropunctation, otherwise without distinct microsculpture; eyes rather large, at least slightly longer than postocular region in dorsal view. Antenna with antennomeres IV-X gradually increasing in width and approximately 1.2-1.5 times as wide as long.

Pronotum approximately 1.35 times as wide as long and 1.7 times as wide as head, widest behind the middle; posterior angles weakly marked; punctation fine and rather sparse; interstices with fine micropunctation, otherwise without microsculpture. 
Elytra $0.75-0.80$ times as long as pronotum; punctation coarser and denser than that of pronotum. Metatarsus approximately 0.8 times as long as metatibia; metatarsomere I elongated, approximately as long as the combined length of II-IV or even longer.

Abdomen with segments III-V of subequal width, segments VI-VIII weakly tapering; tergites III-V with moderately deep anterior impressions; punctation moderately coarse, dense in anterior impressions of tergites III-V and somewhat less dense on remainder of tergal surfaces; posterior margin of tergite concave in the middle.

$\sigma^{7}$ : posterior margin of sternite VIII almost acutely produced in the middle; median lobe of aedeagus with strongly arched, apically lamellate (lateral view) and very acute (ventral view) ventral process, with narrow crista apicalis, and with characteristic internal structures (Figs 143-145); apical lobe of paramere slender, approximately 4-5 times as long as wide.

$\rightarrow$ : posterior margin of sternite VIII broadly convex; spermatheca shaped as in Figs 146-147.

\section{Distribution and bionomics:}

Aleochara maculata has a distribution of the ponto-Mediterranean type, ranging from northeastern Anatolia and the Caucasus region across the Balkans, Italy (north and south) to Great Britain, France, and northwestern Spain (Map 5). PALM (1972) reports a record from Finland. According to Smetana (2004), the species was previously unknown from Spain and Romania. There is considerable doubt that the above specimens with the labels "Strebersdorf" and "Prag" are labelled accurately, since there are no mountain ranges in these localities.

The species is apparently confined to high-altitude habitats. The above material with labels giving reliable data was collected at elevations of $1650-2600 \mathrm{~m}$ by turning stones and by sifting grass roots and litter, often near snow. In Spain and France, it was occasionally found together with A. cristata. One of the above specimens was caught on the wing with a car-net in May.

\section{Aleochara (Xenochara) hamulata nov. sp. (Figs 148-154, Map 5)}

\section{Type material:}

Holotype ơ: "GR. Voiotia, 900 m, 6a, Oros Elikonas, NE Kiriaki, under stones, 38²2'40N, 2249'16E, 04.IV.2001, V. Assing / Holotypus o* Aleochara hamulata sp. n., det. V. Assing 2009" (cAss). Paratypes: $1 o^{\star}$ : "Yu (Kro) Plitvice, Poljanak, 500 m, 09.05.90, Wunderle"

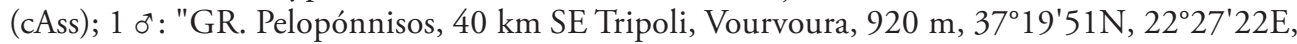
22.III.1997, V. Assing" (cAss); 1 ㅇ: "GR. Pelopónnisos, 40 km SE Tripoli, E Ag. Petros, 900 m,

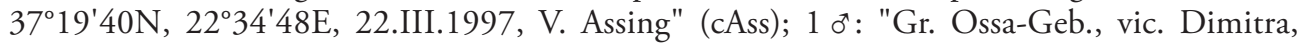
700 m, 26.3.1983, leg. Karner" (cAss); 1 ㅇ: "TR [19] - Izmir, WSW Hamamköy, Murtat Dağı, 1440 m, 38 00'48N, 2756'38E, 9.IV.2006, P. Wunderle" (cWun); 1 : : "TR [16] Aydın, 790 m, Karınçalı Dağı, ca. 5 km WSW Karakasu, 37²2'30N, 28³5'16E, 8.IV.2006, P. Wunderle" (cAss); 1 ㅇ: "Petrowitz-Ressl, Reise nach Kleinasien 1960 / Umg. Akschehir, 4.V.1960 / Sultan-Dagh, im Detritus" (NHMW); $1 \sigma^{\text {: }}$ : Petrowitz-Ressl, Reise nach Kleinasien 1960 / Umg. Akşehir, 15.IV.1960" (cAss); 1 ơ⿱ $^{\text {: }}$ "TR Prov. Isparta, Davras Dagi, 21002400 m, 3746+3044, 31.V.2006, leg. W. Marggi" (cAss); 1 ex.: "TR Prov. Isparta, Barla Dag, nord, $2100 \mathrm{~m}, 30.6 .2006,38^{\circ} 05+30^{\circ} 42$, leg. Marggi (10662), 2100-2400 m, 37 $46+30^{\circ} 44$, 31.V.2006, leg. W. Marggi" (cAss); $10^{\star}:$ "M. R. S. N., Spedizione "Turchia '82", Boffa-CasaleCavazzuti-Giachino-Scaramozzino / Turchia, vil. Antalya, Korkuteli, m 1020, 24.-25.IV.1982"; 1 ơ $^{\star}$ : "N-Irak, N Erbil, Shaqlawa, IV.2007, leg. C. Reuter" (cFel). 


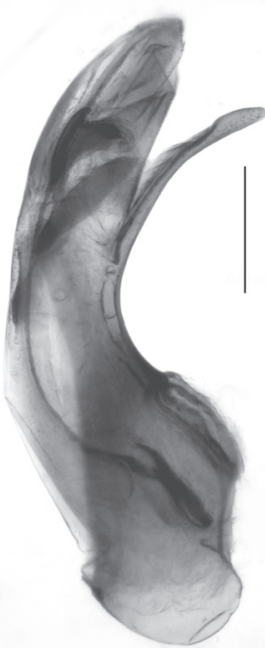

143

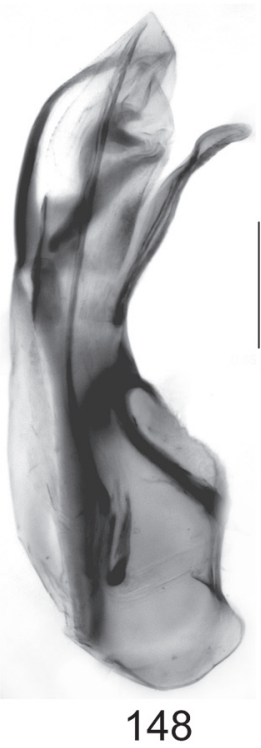

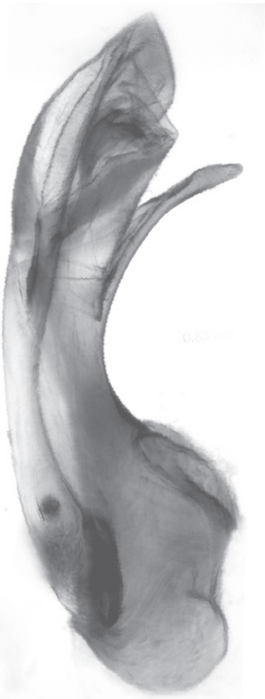

144
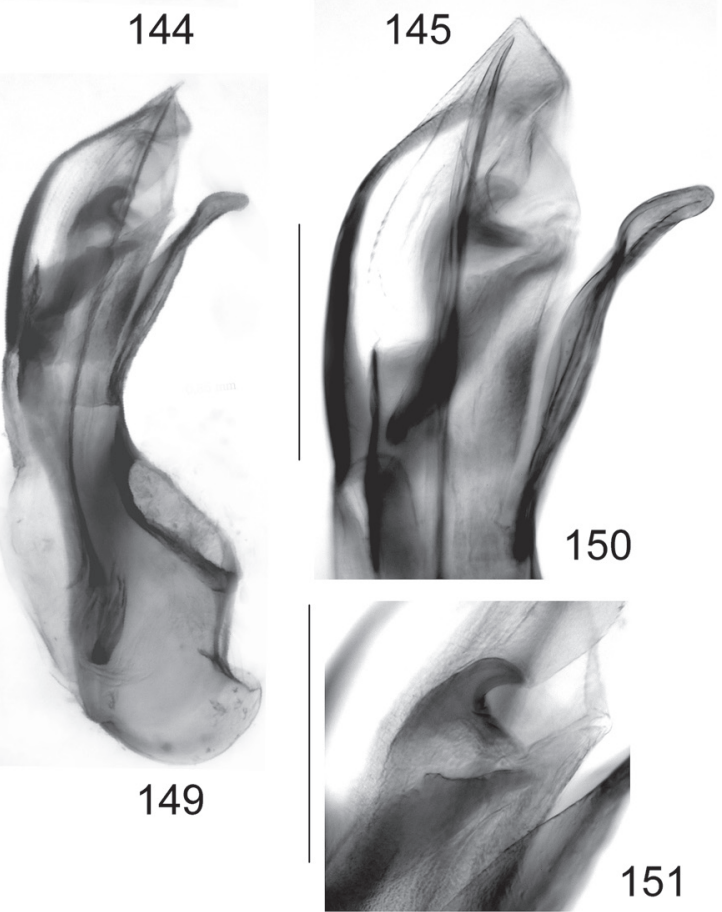
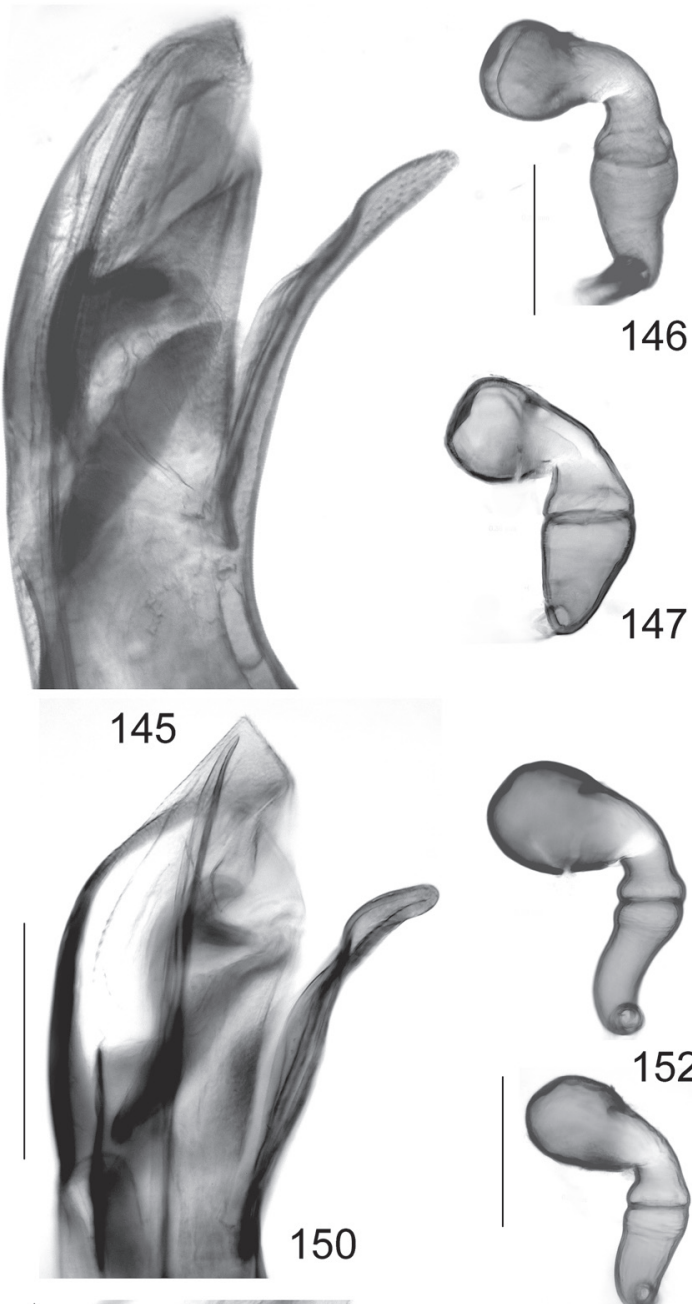

153

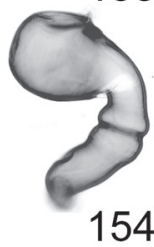

Figs 143-154: Aleochara maculata Brisout De Barneville (143-147) and A. hamulata sp. n. (148-151; 149, 151: holotype): median lobe of aedeagus in lateral view (143-144, 148-149); apical portion of median lobe of aedeagus in lateral view $(145,150)$; spermatheca $(146-147,152-154)$; apical internal structure of aedeagus (151). Scale bars: $0.2 \mathrm{~mm}$. 


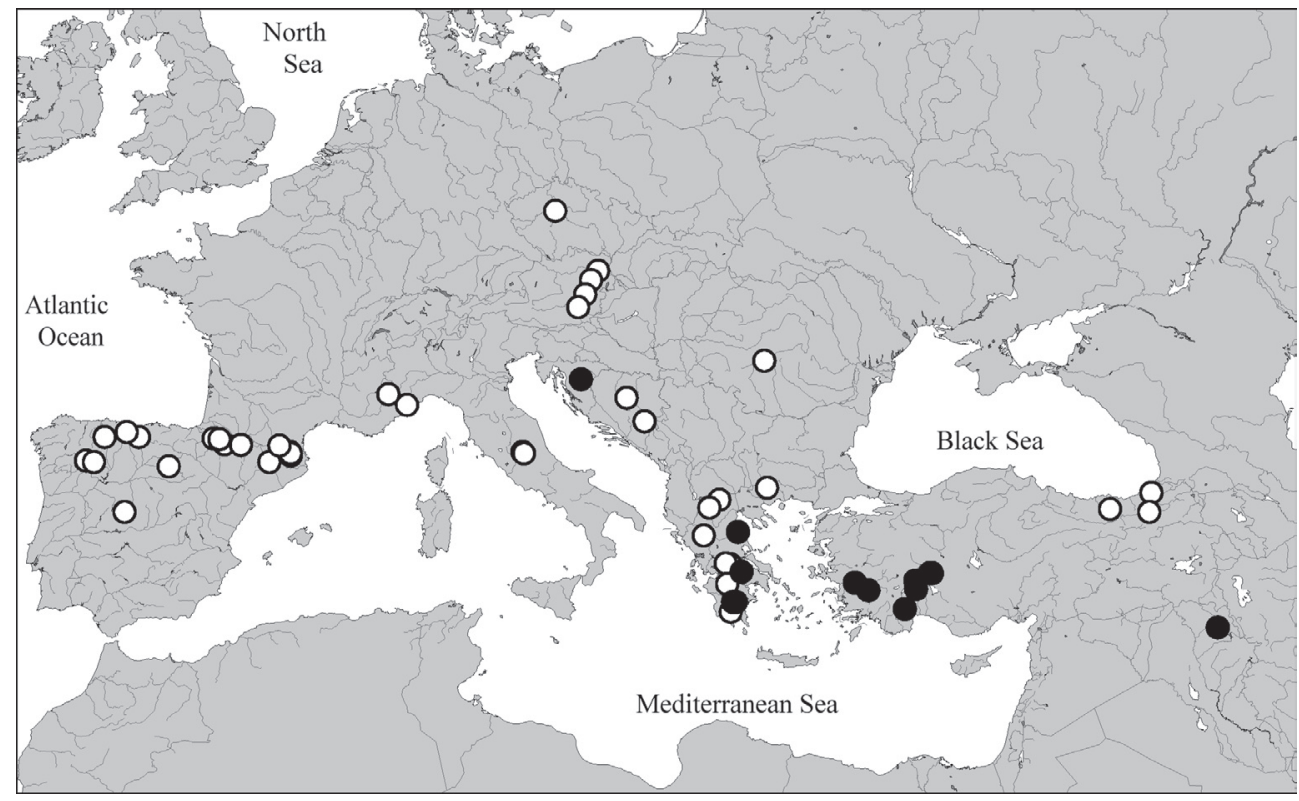

Map 5: Distributions of species of the Aleochara maculata group in the Western Palaearctic region, based on revised records: A. maculata Brisout de BARneville (open circles) and A. hamulata sp. n. (filled circles).

\section{Description:}

Body length: 5.0-7.2 mm. Elytra reddish, with the anterior margin and the suture darkened; legs with the femora dark-brown to blackish-brown, tibiae reddish-brown to dark-brown; tarsi reddish to reddish-brown. Metatarsomere I usually slightly shorter than, rarely as long as the combined length of II-IV. Other external characters as in A. maculata.

$\sigma^{*}$ : posterior margin of sternite VIII acutely angled in the middle; median lobe of aedeagus similar to that of $A$. maculata, but ventral process less strongly arched, apically shorter and less slender, crista apicalis broader, and internal structures of different shape (Figs 148-151); apical lobe of paramere of similar shape as in $A$. maculata.

: posterior margin of sternite VIII broadly convex; spermatheca shaped as in Figs 152-154.

\section{Etymology:}

The name (Latin, adjective: with small hooks) refers to the shape of the apical internal structures of the aedeagus.

\section{Comparative notes:}

The species is distinguished from other species of the $A$. maculata group particularly by the reddish elytra and by the shape of the median lobe of the aedeagus. The crista apicalis of the aedeagus is broader than in $A$. maculata, but distinctly narrower than in $A$. cristata.

\section{Distribution and bionomics:}

The species is known from several localities in central and southern Greece, Croatia, western and southwestern Anatolia, and in Iraq (Map 5). The species does not appear to be strictly confined to montane and subalpine habitats, since it was found also at lower elevations (790-2400 m). 
The type specimens were found under stones, and sifted from litter and moss in forests (Abies, Quercus ilex, Platanus, Castanea) and from grass roots.

\section{Aleochara (Xenochara) cornuta FAUVEL, 1886 (Figs 155-161, Map 6)}

Aleochara cornuta FAUveL, 1886: 94.

\section{Type material examined:}

Lectotype ơ, present designation: "Omessa / cornuta Fvl. / Type / Coll R. I. Sc. N. B. / Lectotypus o Aleochara cornuta Fauvel, desig. V. Assing 2009 / Aleochara cornuta Fauvel, det. V. Assing 2009" (IRSNB).

\section{Additional material examined:}

Morocco: $10^{*}, 1$ \% , Haut Atlas, NE Tizi-n-Test, 30 $55^{\prime} \mathrm{N}, 08^{\circ} 17^{\prime} \mathrm{W}, 1540 \mathrm{~m}$, near stream, 29.XII.2002, leg. Assing \& Wunderle (cAss); 1 ㅇ, Moyen Atlas, road 3390/3395, ca. 20 km SE Ain-Leuh, ca. 1800 m, 13.V.1995, leg. Aßmuth et al. (cWun).

France: Corse: $2 \sigma^{\star} o^{\star}, 1$, Haute-Corse, col de Vizzavona, $1200 \mathrm{~m}$, beech litter, 22.V.1972, leg. Tronquet (cTro, cAss); 2 ㅇ 우, Corse-du Sud, Evisa, 1000 m, car-net, 24.V.1972, leg. Tronquet (cTro); 1 ㅇ, Corse-duSud, Tula, 11.VII.1980, leg. Tronquet (cTro); 1 ㅇ, S. Cozzano, 800 m, 8.V.2001, leg. Wolf (cSch).

\section{Comment:}

The original description is based on an unspecified number of type specimens from "O. Daya (Bedel)" and "Corse (Omessa)" (Fauvel 1886). The syntype from Omessa, a male, was located in the Fauvel collection and is designated as the lectotype. An examination of material previously identified as $A$. cornuta from various localities in the Western Mediterranean revealed that two species have been confounded under this name.

\section{Redescription:}

Body length: 4.5-7.5 mm. Elytra uniformly black. Metatarsomere I at most as long as the combined length of II-IV. Other external characters as in A. maculata.

$0^{\text {t }}$ : tergite VIII as in Fig. 159; posterior margin of sternite VIII distinctly produced in the middle (Fig. 160); median lobe of aedeagus $0.70-0.80 \mathrm{~mm}$ long, similar to that of $A$. maculata, but ventral process less strongly arched, apically shorter, less slender, and less acute in lateral view (Figs 155-157); apical sclerotised internal structures of different shape (Fig. 158); apical lobe of paramere of similar shape as in $A$. maculata.

$\rightarrow$ : posterior margin of sternite VIII broadly convex; spermatheca shaped as in Fig. 161.

\section{Comparative notes:}

The species is distinguished from other species of the $A$. maculata group by the morphology of the median lobe of the aedeagus and, except for $A$. cristata, by the uniformly black coloration of the elytra. For characters separating it from the externally similar $A$. cristata see the following section.

\section{Distribution and bionomics:}

The species has been reported from Northwest Africa (Morocco, Algeria), Spain, and southern France, including Corsica (Smetana 2004; Tronquet 2006). However, since A. cornuta of previous authors is in fact represented by two distinct species, the distribution of the true $A$. cornuta requires revision. At present, confirmed records are known only from Corsica and Morocco (Map 6). 
Some of the specimens examined were sifted from leaf litter near a stream and in a beech forest. One specimen was caught with a car-net in May. Bernhauer (1901) exclusively knew records from human faeces. The altitudes range from 800 to $1800 \mathrm{~m}$.

Aleochara (Xenochara) cristata nov. sp. (Figs 162-168, Map 6)

\section{Type material:}

Holotype $\sigma^{\star}$ : "E - Andalucía [15], Sierra de los Filabres, S. Serón, $1800 \mathrm{~m}$, grassland, $37^{\circ} 15^{\prime} 44 \mathrm{~N}$, 02³0'30W, 19.III.2008, V. Assing / Holotypus ơ Aleochara cristata sp. n., det. V. Assing 2009" (cAss). Paratypes: $10^{\star}$ : same data as holotype (cAss); 1 : "E - Andalucía [13], W Almeria, Sierra de Gádor, $2120 \mathrm{~m}, 36^{\circ} 53^{\prime} 51 \mathrm{~N}, 02^{\circ} 49^{\prime} 20 \mathrm{~W}, 18 . I I I .2008$, C. Andújar \& V. Assing" (cAss); 1 o $^{\star}$ : "E - No. 25; $60 \mathrm{~km}$ E Teruel, Sierra del Rayo, E Valdelineares, $1800 \mathrm{~m}, 40^{\circ} 23^{\prime} 18 \mathrm{~N}, 00^{\circ} 31^{\prime} 09 \mathrm{~W}$, 13.IV.2003, leg. V. Assing" (cAss); 1 o $^{\star}, 1$ ㅇ: same data, but leg. Wunderle (cWun); $2 o^{\star} o^{\star}, 2$ ㅇ : "Spanien: Burgos, Straße von Palacio de la Sierra nach S., 1000-1200 m, 27.05.1994, Autok., Schülke \& Grünberg" (cSch, cAss); 1 \%: "Spanien: Burgos, Sierra de Neila, Campino, 15001900 m, 25.05.1994, Schülke \& Grünberg" (cSch); 1 đo: "Spanien: Burgos, Sierra de Neila, Straße v. El Collado n. Quintanar, 27.05.1994, Schülke \& Grünberg" (cSch); 1 : : España (Av), Sierra de Gredos, 1700 m, 123-22/V-1992, P. Poot" (cWun); 1 ơ: "E (NW) Reinosa, Tres Mares/Cornon,

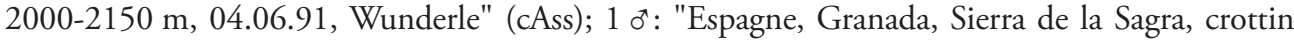
[horse dung], $1400 \mathrm{~m}, \mathrm{M}$. Tronquet, 22/04/2000" (cTro); $10^{\star}, 1$ 오 :Espagne, Granada, Sierra de la Sagra, 2300-2380 m, [snowfield], M. Tronquet, 30-04-91" (cTro, cAss); 1 o': "Espagne, Granada, Sierra Nevada, Puerto de la Ragua, 2000-2300 m, M. Tronquet, 28-04-91" (cTro); 1 q : "Espagne, Teruel, Sierra de Javalambre, litière et racines [shrub litter], $2000 \mathrm{~m}, \mathrm{M}$. Tronquet, 26/04/2000" (cTro); 1 ㅇ: "P - Serra da Estrela, 12, S Manteigas, 1073 m, bushes, under stones,

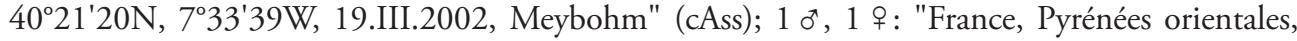
Réserve naturelle de Nohèdes, Piégeages bouses [dung trap], 1150/1600 m, G. Pinault leg., 5/95" (cTro); 1 q: "France, Pyrénées-Orientales, Jujols, F. Soldati leg., 15/05/2002" (cTro); 1 q: "France, Pyrénées-Orientales, Jujols, piége d'interception [1500-1800 m, window trap], O.N.F. leg., 14 au 21.05.2002" (cTro); 1 o : "France, Pyrénées-Orientales, Molitg-les-Bains, latrines blaireau [800 m, badger dung], M. Tronquet, 01.03.02" (cTro); $10^{\star}:$ "NG.16025 France Var (83), Plan-

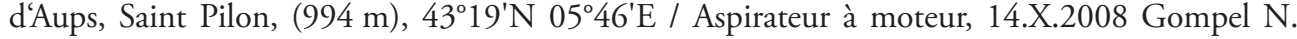
Leg." (cGom); 1 o`: "Teniet el Had / Taquin (Alg.) / Chellala / Coll. R. I. Sc. N. B" (IRSNB); 1 o: "Mazargues près Marseille, 2,3, excréments / cornuta Fvl. / Coll. R. I. Sc. N. B" (IRSNB).

\section{Description:}

Body length: 4.5-7.5 mm. External and secondary sexual characters as in $A$. cornuta, distinguished only by the male primary sexual characters:

$0^{7}$ : sternite VIII similar to that of $A$. cornuta; median lobe of aedeagus $0.75-0.90 \mathrm{~mm}$ long, similar to that of $A$. cornuta, but ventral process of median lobe subapically more or less distinctly sinuate in lateral view; crista apicalis very large (Figs 162-165); apical internal structures and apical lobe of paramere of similar shape as in A. cornuta (Figs 165-167).

ㅇ: spermatheca shaped as in Fig. 168.

\section{Etymology:}

The name (Latin, adjective) refers to the narrow crista apicalis of the aedeagus, one of the characters distinguishing this species from the highly similar $A$. cornuta. 


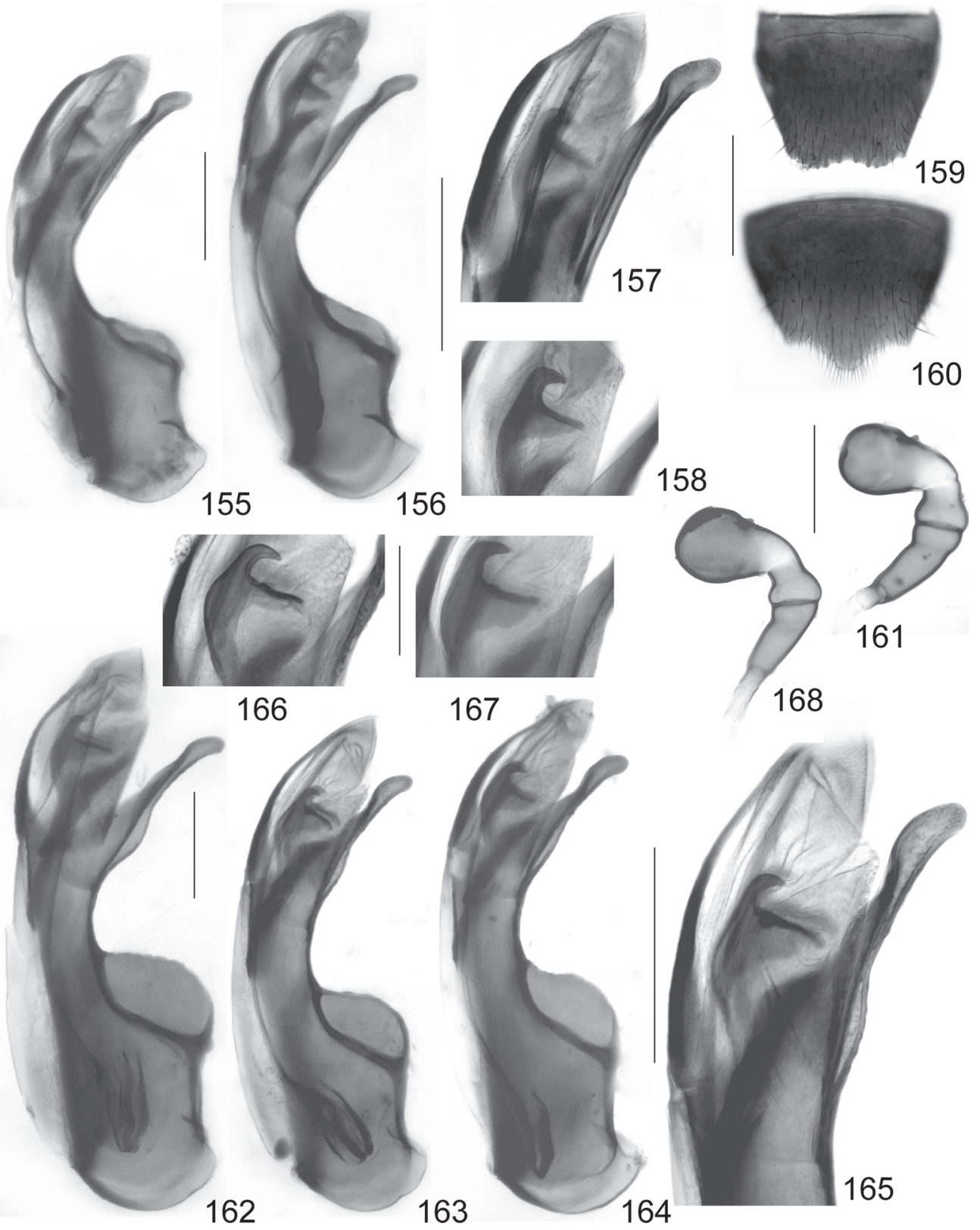

Figs 155-168: Aleochara cornuta Fauvel (155-161; 155, 157, 159-160: lectotype) and A. cristata sp. n. (162-168; 163, 165: holotype): median lobe of aedeagus in lateral view (155-156, 162-164); apical portion of median lobe of aedeagus in lateral view $(157,165)$; apical internal structure of aedeagus $(158$, 166-167); male tergite VIII (159); male sternite VIII (160); spermatheca $(161,168)$. Scale bars: 155-165, 168: $0.2 \mathrm{~mm}$; 166-167: $0.1 \mathrm{~mm}$. 


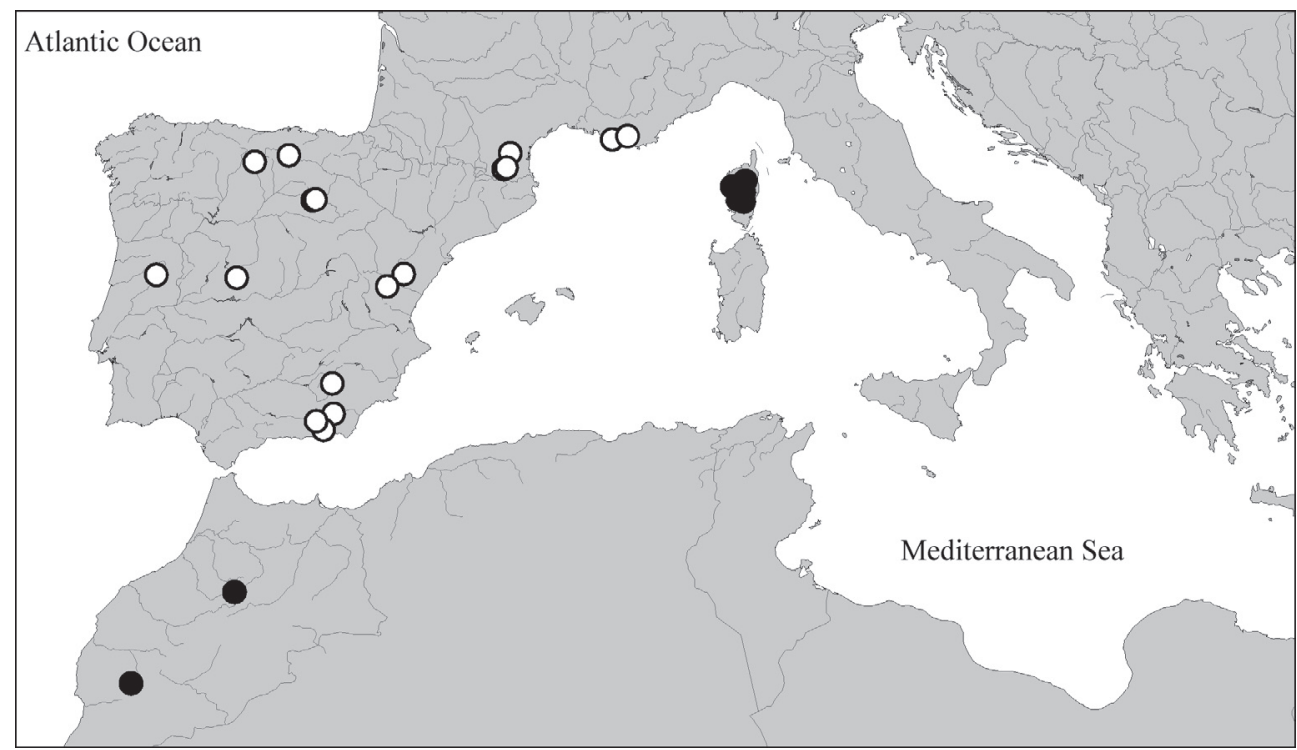

Map 6: Distributions of species of the Aleochara maculata group in the Western Mediterranean region, based on revised records: $A$. cornuta Fauvel (filled circles) and $A$. cristata sp. n. (open circles).

\section{Comparative notes:}

Aleochara cristata is distinguished from other species of the $A$. maculata group by the morphology of the aedeagus and, except for $A$. cornuta, by the uniformly blackish elytra. It is reliably separated from the highly similar $A$. cornuta only by the male primary sexual characters, i. e., the much larger crista apicalis and the subapically sinuate ventral process (lateral view).

\section{Distribution and bionomics:}

Aleochara cristata is evidently rather widespread in the Western Mediterranean and currently known from Spain, Portugal, and southern France, eastwards to the environs of Marseille (Map 6). One of the paratypes has three different labels with Algerian localities attached to it, so there is still some doubt as to whether the species is really present in Algeria.

The type specimens were found under stones, sifted from grass roots, tree and shrub litter, repeatedly near snowfields, and collected from dung (badger, horse) at altitudes of mostly 1400$2400 \mathrm{~m}$, one specimen also at $800 \mathrm{~m}$; five specimens were collected on the wing with car-nets and window traps $(1000-1800 \mathrm{~m})$ in May and August. On several occasions, the species was found together with $A$. maculata.

\section{Notes on the taxonomy and zoogeography of other Xenochara species}

\section{Aleochara (Xenochara) lygaea KRAATZ, 1862 (Figs 169-171)}

\section{Material examined:}

France: $2 o^{\star} o^{\star}, 2$ ㅇ 우, Haute Provence, Annot env., 900 m, VI.1988, leg. Wunderle (cWun, cAss).

Germany: $10^{\star}$, Sachsen-Anhalt, Krüden, deer carrion, 21.V.1993, leg. Wunderle (cWun); $1 \overbrace{}^{\star}$, Sachsen, Großschönau, 6.IV.1967, leg. Sieber (cWun). 
Austria: 1 ơ $^{\circ} 1$ ㅇ, Osttirol, Kals, stream, 7.VIII.1995, leg. Feldmann (cAss).

Bosnia-Herzegovina: $1 \sigma^{\star}$, road from Kraljeva-Sutesca to Mostre, arable land, car-net, 5.V.1990, leg. Wunderle (cWun); 1 \%, Vlasic planina, 600-1700 m, car-net, 5.V.1990, leg. Wunderle (cWun).

Turkey: see Assing (2007a).

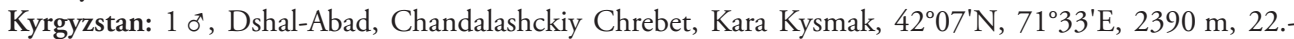
23.VII.2006, leg. Schmidt (cAss); 1 ㅇ, Talass, Kirgizskiy Alatau, Terek-Sai valley, $42^{\circ} 34^{\prime} \mathrm{N}, 72^{\circ} 43^{\prime} \mathrm{E}, 1850 \mathrm{~m}$, 18.-20.VII.2006, leg. Schmidt (cAss).

China: 3 exs., Gansu, Xiahe (= Labrang) env., 35 $12^{\prime} \mathrm{N}, 102^{\circ} 31^{\prime} \mathrm{E}, 2940 \mathrm{~m}$, in burrows and excrements of Marmota himalayana, 19.-22.VI.2005, leg. Hájek et al. (cSch, cAss).

\section{Comment:}

The above specimens from Kyrgyzstan represent new country records and the first records from the whole of Middle Asia. In China, this species was previously known only from Heilongjiang province (SMETANA 2004). The primary sexual characters of the specimens from Kyrgyzstan are illustrated in Figs 169-171.

\section{Aleochara (Xenochara) peeziana LoHSE, 1961 (Figs 172-175)}

Aleochara peeziana LoHse, 1961: $187 \mathrm{f}$.

\section{Type material examined:}

Lectotype $\sigma^{\star}$, present designation [dissected prior to present study]: "I. S.Tir. Brixen, Tschötscher Heide, 17.IX.63, Peez / Aleochara peeziana Lohse / Holotypus [sic] / Aleochara peeziana / Lectotypus Aleochara peeziana Lohse, desig. V. Assing 2009 / Aleochara peeziana Lohse, det. V. Assing 2009" (MHNG).

\section{Additional material examined:}

Norway: $1 \sigma^{\star}$, Finnmark, Pasvik-Järvi, VII.1944, leg. Nietsch (NHMW).

Finland: 1 ㅇ, Rovaniemi, V.1943, leg. Nietsch (NHMW); 1 ㅇ, Helsingfors, leg. Nietsch (NHMW).

Denmark: 1 đa, 2 exs., locality not specified, leg. Suenson (NHMW).

Germany: $1 \sigma^{\star}, 1$ \% , Niedersachsen, Helmstedt env. (NHMW, cAss); 1 \%, S Braunschweig, rotting leaves, 4.XI.1964, leg. Schuster (cAss).

Switzerland: $1 \sigma^{\star}$, Graubünden, S Santa Maria, Umbrailpass, 2300 m, marmot dung, 30.IX./5.X.1988, leg. Wunderle (cWun); 1 đ', Valais, Bürchen, leg. Ziegler (NHMW).

Austria: Kärnten: 1 † , Niedere Tauern, Tamsweg, 1200 m, cow dung, 23.VII.1991, leg. Assing (cAss); $1 \delta^{*}$, 1 , Dobratsch, VIII.1903, leg. Schatzmayr (NHMW, cAss); $10^{*}$, Aichwaldsee, 20.VII.1956, leg. Mandl (NHMW); 1 ex., Hochobir, leg. Schweiger (NHMW).

Italy: 1 ex., Trentino-Alto Adige, Pozza di Fassa, Malga di Crocifisso, 1300 m, VII.1961, leg. Bilardo (NHMW); 1 ex., Veneto, Alpi Lessini, leg. Breit (NHMW); 1 ex., Friuli-Venezia Giulia, Pontebba, leg. Manderek (NHMW); 2 o $^{\star}$, Friuli-Venezia Giulia, Ampezzo, leg. Breit (NHMW, cAss).

Czech Republic: 2 exs., Praha, leg. Skalitzky (NHMW, cAss).

Slovenia: $1+$, Maribor (NHMW).

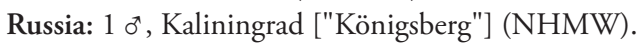

\section{Comment:}

Lohse (1961) described A. peeziana as a nomen novum ("A. peeziana n. n.") for Scheerpeltz' interpretation of $A$. lanuginosa Gravenhorst [sic], based on the "Cotypen von Brixen" [sic] and on an unspecified number of syntypes from the "Karawanken" collected by himself and by other coleopterists. 
The species has been reported from various localities in the Alps, from Scandinavia, and even from Armenia (Likovský 1971, 1974; Palm 1972; Smetana 2004). It is here reported from Denmark, northern Germany, Slovenia and Russia for the first time. The record from Armenia requires confirmation. Based on the similarly derived morphology of the median lobe of the aedeagus (membranous base of capsule, very long, slender, and acute ventral process, position of crista apicalis, apical structures of the internal sac), A. peeziana is closely related to A. lygaea. For illustrations of the genitalia see Figs 172-175.

\section{Aleochara (Xenochara) persica LıKOVsKर́, 1981}

Aleochara (Polychara) persica Lıкоvsќ́, 1981: $361 \mathrm{f}$.

Material examined:

Turkmenistan: 1 ơ, 30 km W Kasandshik, 13.IV.1993, leg. Predel (cAss).

\section{Comment:}

The species was originally described from the eastern Elburs range, northern Iran (LikovskÝ 1981) and has never been recorded since. The above specimen represents the first record from Turkmenistan.

\section{Aleochara (Xenochara) falsa Lıкоvsки́, 1981}

Aleochara (Polychara) falsa Likovskŕ, 1981: 362 ff.

Material examined:

Iran: Fars: 4 exs., road Sepidan-Komehr, 9 km NW Sepidan, 30²2' N, 51ํ5'ㄹ, 2790 m, 8.V.2007, leg. Frisch \& Serri (MNHUB, cAss); 10 exs., road Sepidan-Komehr, $3 \mathrm{~km} \mathrm{NW}$ Sepidan, 30²1'N, 51 ${ }^{\circ} 57^{\prime} \mathrm{E}$, 2850 m, 8.V.2007, leg. Frisch \& Serri (MNHUB, cAss). Esfahan: 2 exs., S Semirom, Komeh, $31^{\circ} 01^{\prime} \mathrm{N}$,

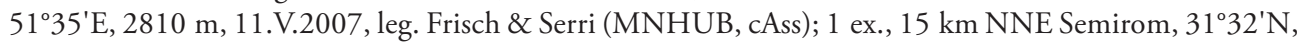
$51^{\circ} 37^{\prime} \mathrm{E}, 2650 \mathrm{~m}, 12 . \mathrm{V} .2007$, leg. Frisch \& Serri (cAss).

\section{Comment:}

The above specimens represent the first records since the original description, which is based on a single male from "West Iran, Zagros, Marg-e Malek, 3200 m" (LiкоvsкÝ 1981).

\section{Aleochara (Xenochara) lepidoptera BERnHAUER, 1901}

Aleochara (Isochara) lepidoptera Bernhauer, 1901: 463.

Material examined:

Turkey: 1 ex., Gümüşhane, ca. 12 km NE Gümüşhane, ca. 40³1'N, 39³3'E, 1300 m, 12.VI.1998, leg.

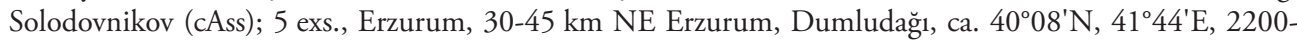
2500 m, 14.VI.1998, leg. Solodovnikov (cAss).

Tajikistan: 3 exs., Pamir Alai, Hissar Mts., Adshuk cleft near Warsob, 1200 m, 1.-3.VII.1990, leg. Schülke $\&$ Wrase (cAss, cSch). 


\section{Comment:}

This species was originally described as a variety of $A$. moesta Gravenhorst, 1802, based on material from the Caucasus region (BERnhaUer 1901). The previously known distribution included also western and eastern Siberia, Mongolia, and Iran (Likovskŕ 1972, 1981; Smetana 2004). The above specimens represent the first records from Turkey and Tajikistan. In the locality in Erzurum province, northeastern Anatolia, A. lepidoptera was collected together with the closely related $A$. moesta (Assing 2007a).

\section{Aleochara (Xenochara) nigerrima KraATZ, 1856 (Fig. 176)}

Aleochara nigerrima KRAATZ, 1856: 104.

Type material examined:

Syntype + : "6 / 56 / nigerrima mihi, Hisp. Hdschh. / coll. Kraatz / Syntypus / coll. DEI Müncheberg / Syntypus o Aleochara nigerrima Kraatz, rev. V. Assing 2009 / Aleochara nigerrima Kraatz, det. V. Assing 2009" (SDEI).

Additional material examined:

Spain: 1 \% , Andalucía, Cádiz, Zahara de los Atunes, 14.-21.III.1990, leg. Matern (cAss).

\section{Comment:}

The original description is based on an unspecified number of syntypes collected "von Handschuch [sic] in Spanien" (Kraatz 1856). One - most likely the only - syntype, a female, was located in the Kraatz collection at the SDEI. Its spermatheca is illustrated in Fig. 176.

The species has been recorded only from Spain and Algeria (Smetana 2004). It somewhat resembles a very large specimen of $A$. laevigata, but is distinguished from that species by distinctly longer and more slender antennae, much sparser and finer punctation of the abdomen, very large and well-defined reddish-yellow elytral spots, and a spermatheca of completely different shape.

\section{Aleochara (Xenochara) tenuicornis KRAATZ, 1856 (Figs 177-178)}

Aleochara tenuicornis KraATZ, 1856: 89.

Aleochara rufipes Mulsant \& ReY, 1853: 63; primary homonym.

\section{Type material examined:}

Lectotype $\sigma^{\text {* }}$ : "tenuicornis mihi, rufipes Muls. Gall. / coll. Kraatz / Syntypus / coll. DEI Müncheberg / Lectotypus ơ Aleochara tenuicornis Kraatz, desig. V. Assing 2009 / Aleochara tenuicornis Kraatz, det. V. Assing 2009" (SDEI). Paralectotypes: 1 ex.: "Corsica / coll. Kraatz" (SDEI); 1 ex.: "Italia / coll. Kraatz" (SDEI).

Additional material examined:

Spain: 1 \& , Andalucía, Huelva, El Rocío, Arroyo la Rocina, 22.IV.2003, leg. Ribera et al. (cAss); 1 , Huelva, Acebuche, 28.VII.1971 (cAss); 1 ơ, S-Mallorca, Salines de Llevant, 20.III.2003, leg. Ziegler (cAss).

France: 1 ex., Camarque, Salin de Girault, 27.VI.1991, leg. Stehling (cAss).

Italy: 1 ex., Puglia, S. Cataldo (LE), Ris. WWF Le Cesine, 14.-17.VII.1995, leg. Angelini (cAss); 1 ex., Sardegna, Budoni (NU), Cala di Budoni, 3.V.1995, leg. Angelini (cAss).

Greece: 1 ex., "Lagas", lagunas, 5.VIII.1984, leg. Derra (cAss); 1 ơt, Ebros delta, 17.V.1991, leg. Schillhammer (cAss). 
Israel: $1 \sigma^{*}$, Central district, Netanya, Breikhat Dora res., wetland, 27.III.2008, leg. Wrase (cSch); 1 ex., Golan Heights, Bental reservoir, W Merom Golan, ca. 1000 m, stony wetland near shore, 30.IV.2006, leg. Wrase (cSch); 7 exs., same data, but 25.III.2008, leg. Aßmann, Wrase (TAU, cAss, cFel, cSch).

Russia: 9 exs., Astrakhan region, 30 km ESE Kapustin Yar, Dmitrievka village, 30.-31.V.2000 (cSch, cAss). Kazakhstan: 2 exs., 25 km N Beyneu, 8.V.2000, leg. Karalius \& Miatleuski (cSch, cAss).

Locality doubtful: 1 ex., "Cassel / coll. Kraatz" (SDEI).

\section{Comment:}

KraAtz (1856) described A. tenuicornis, stating that it was conspecific (and synonymous) with the primary homonym $A$. rufipes Mulsant \& Rey, 1853 and that it had been found only "im südlichen Europa". Since he provides characters distinguishing it from A. rufipennis ErICHSON, 1839 (today a synonym of $A$. haematoptera KRAATZ, 1858), his introduction of the name may be regarded as a description, not merely a replacement of a name, and the material seen by him may be considered type material. Three specimens qualifying as syntypes were found in the collections at the SDEI. A male with Kraatz' original identification label is designated as the lectotype. Its aedeagus is illustrated in Figs 177-178.

In external appearance (size, coloration, coarse punctation of the abdomen), A. tenuicornis is highly similar to $A$. haematoptera, but at once distinguished by the much more slender antennae. The antennomeres IV and V are somewhat oblong (A. haematoptera: transverse) and the preapical antennomeres are only weakly transverse (A. haematoptera: almost twice as wide as long).

The species was previously known only from southern Europe (from Spain to Greece) and North Africa (Smetana 2004). It is here reported from Israel, Russia, Kazakhstan and the whole of Middle Asia for the first time. Interestingly, the species appears to be subject to clinal variation in coloration. While the material seen from southern Europe has the elytra yellowish to reddish with the lateral and the anterior margins, as well as the scutellar area narrowly blackish, the black coloration of the specimens from Israel is much more extensive (leaving only a spot on the elytral disc reddish, and the material seen from Russia and Middle Asia has uniformly reddish elytra.

\section{Aleochara (Xenochara) brevipennis GRAVENHORST, 1806}

Material examined:

Kazakhstan: 4 exs., Serebrovskyi district, Severnoe village, 10.-20.VII.2000, leg. Kiritchenko (cSch, cAss).

\section{Comment:}

According to Smetana (2004), this widespread trans-Palaearctic species was previously unknown not only from Kazakhstan, but from the whole of Middle Asia.

\section{Aleochara (Xenochara) ignipennis FAUVEL, 1900 (Figs 179-181)}

Aleochara ignipennis FAUVEL, 1900: $247 \mathrm{f}$.

Type material examined:

Holotype + : "Persia settent. / ignipennis Fvl / R.I.Sc.N.B. 17.479, Aleochara, Coll. et det. A. Fauvel / Type / Holotypus o Aleochara ignipennis Fauvel, rev. V. Assing 2009 / Aleochara ignipennis Fauvel, det. V. Assing 2009" (IRSNB). 
Additional material examined:

Turkey: 1 ơ $^{\star}$, Adana, NW Pozanti, Çaykavak geçidi, 1600 m, 22.VII.1998, leg. Bayer (cAss).

\section{Comment:}

The original description is based on a single specimen from "Perse septentrionale" (FAUVEL 1900). An examination of the holotype revealed that it is a female. The male listed as additional material above has a distinctly sparser punctation of the abdomen and darker blackish-brown legs and antennae (reddish in the holotype), but since no additional differences were found, they are attributed to intra- rather than interspecific variation. Males from Iran are needed to confirm that both specimens are conspecific. The aedeagus of the male from Turkey and the abdomen of the holotype are illustrated in Figs 179-181.

The species has been reported from Iran, Armenia, Azerbaijan, and Turkey (Assing 2007b).

\section{Aleochara (Xenochara) discipennis Mulsant \& REY, 1853}

\section{Material examined:}

Spain: 1 ex., Andalucía, Cádiz, Tarifa, III.1999, leg. Poot (cWun); 1 ex., Tarifa, IV.1991, leg. Poot (cAss); 3 exs., Tarifa, cattle pastures, 124.-21.III.1990, leg. Matern (cWun, cAss).

France: 1 ex., Pyrénées-Atlantiques, Escot, 1.VII.1977, leg. Poot (cWun).

\section{Comment:}

The distribution of this widespread, but rarely recorded species ranges from Spain to Turkey (Assing 2007a; Smetana 2004).

\section{Aleochara (Xenochara) maculipennis BAUdI DI SELVE, 1857}

\section{Material examined:}

Turkey: 1 ex., "Yarpaz" [recte Yarpuz?], 8.-12.V.1982, leg. Rydh (cWun). Syria: 1 đo, Tartus, 6.IV.1990, leg. Reuter (cFel).

Israel: 1 ex., Zefat, light trap, 20.VI.2006, leg. Kuslitzky (TAU); 1 ex., Golan Heights, Bental reservoir, W Merom Golan, ca. 1000 m, stony wetland near shore, 30.IV.2006, leg. Wrase (cSch); 1 ex., same locality, 25.III.2008, leg. Aßmann (cFel).

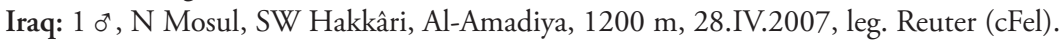

Iran: 1 ex., Kermanshah province, Harsin: Nosratabad, $34^{\circ} 12^{\prime} \mathrm{N}, 47^{\circ} 46^{\prime} \mathrm{E}, 1700 \mathrm{~m}, 24 . \mathrm{VI} .2004$, leg. Frisch (MNHUB); 1 ex., Lorestan province, SE Dorud, Saravand, 2050 m, 27.VI.2004, leg. Frisch (cAss).

\section{Comment:}

The above specimen from Turkey was probably collected in Yarpuz in Antalya; to my knowledge, there is no Turkish locality called "Yarpaz". The previously known distribution of this species was confined to Cyprus, "Syria", and Turkey; in Turkey it was recently recorded from Konya, Kahramanmaraş, Urfa, and Hakkâri (Assıng 2007a). The above specimens from Iran, Iraq, and Israel represent new country records. 

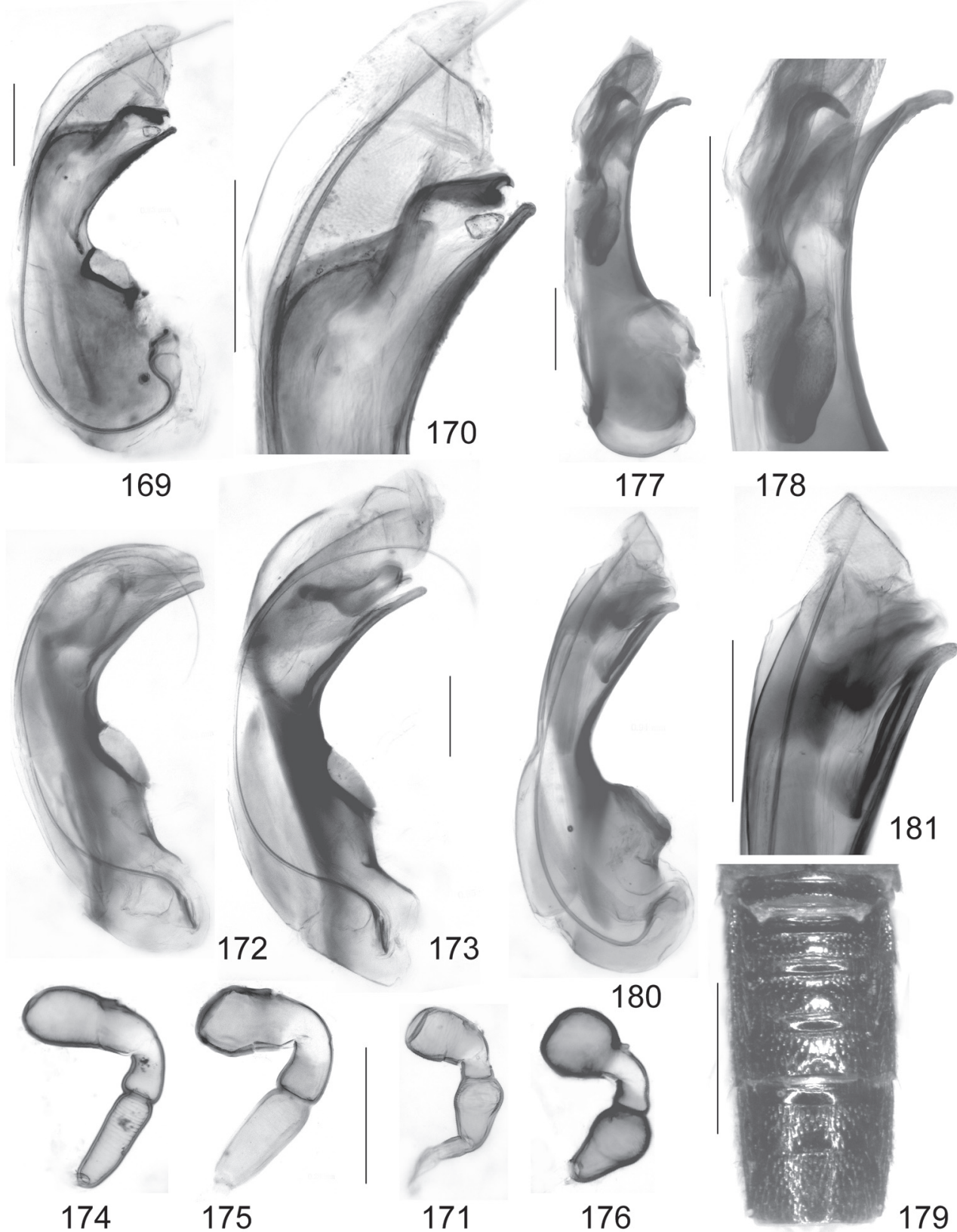

Figs 169-181: Aleochara lygaea KraATz (169-171; Kyrgyzstan), A. peeziana LoHSE (172-175), A. nigerrima Kratiz (176; syntype), A. tenuicornis KraAtz (177-178; lectotype), and A. ignipennis Fauvel (179-181; 179: holotype): median lobe of aedeagus in lateral view $(169,172-173,177,180)$; apical portion of median lobe of aedeagus in lateral view $(170,178,181)$; spermatheca $(171,174-176)$; abdominal segments III-VII (179). Scale bars: 179: $1.0 \mathrm{~mm}$; 169-178, 180-181: $0.2 \mathrm{~mm}$. 


\section{Aleochara (Xenochara) tristis GraVENHORST, 1806}

\section{Material examined:}

Kyrgyzstan: 2 exs., Zalal-Abad, Tasch-Kumyr, $41^{\circ} 26^{\prime} \mathrm{N}, 72^{\circ} 15^{\prime} \mathrm{E}, 650 \mathrm{~m}, 17 .-18 . V I I .2003$, leg. Schmidt (cAss); 1 ex., Osch, NP Kara Shoro, 4045'N, 740'', 2200-2600 m, 19.-20.VII.2003, leg. Schmidt (cAss);

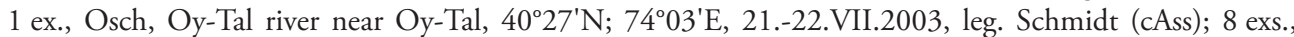
Batken, Kyzyl-Kija, 4016'N, 7209'E, 1000 m, 15.IV.2007, leg. Schmidt (cAss); 1 ex., Cuj, Ssuusamyr valley, $42^{\circ} 11^{\prime} \mathrm{N}, 73^{\circ} 27^{\prime} \mathrm{E}, 2400 \mathrm{~m}, 14 .-15 . V I I .2003$, leg. Schmidt (cAss); 2 exs., Talass, Tshytshkan valley, $42^{\circ} 07^{\prime} \mathrm{N}, 72^{\circ} 49^{\prime} \mathrm{E}, 1700 \mathrm{~m}, 15 .-16 . V I I .2003$, leg. Schmidt (cAss); 13 exs., Talass, Kirgizskyi Alatau, Terek

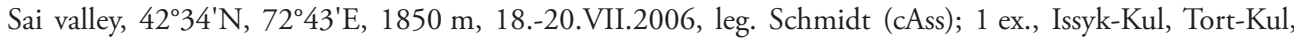
$42^{\circ} 07^{\prime} \mathrm{N}, 76^{\circ} 56^{\prime} \mathrm{E}, 1760 \mathrm{~m}, 11 . \mathrm{IV} .2007$, leg. Schmidt (cAss); 1 ex., Issyk-Kul, Talass valley, Talass river near Kyrk-Kasyk, $42^{\circ} 30^{\prime} \mathrm{N}, 72^{\circ} 26^{\prime} \mathrm{E}, 1400$ m, 20.VII.2006, leg. Schmidt (cAss); 3 exs., Jalan-Abad, Arslanbob, 2100 m, 1.VII.2003, leg. Lackner (cAss); 1 ex., Naryn, Moldo-Too Ch., Suulu-Kurtka river, $41^{\circ} 38^{\prime} \mathrm{N}$, 7502'E, 2350 m, 30.-31.VII.2006, leg. Schmidt (cAss).

Tajikistan: 5 exs., Pamir Alai, Hissar Mts., Adshuk cleft near Warsob, 1200 m, 1.-3.VII.1990, leg. Schülke \& Wrase (cAss); 1 ex., Seravshan range, Marguzar lakes, 6th lake, Hurdak, 1960-2400 m, 20.-30.IV.1997, leg. Beldak (cAss).

\section{Comment:}

The above specimens represent the first records of this common and widespread, almost Cosmopolitan species from Kyrgyzstan and Tajikistan.

\section{Aleochara (Xenochara) sanguinea (Linnaeus, 1758) (Figs 182-183)}

Material examined:

Azerbaijan: $1 \sigma^{\star}$, Lenkoran, leg. Leder (NHMW).

\section{Comment:}

According to Smetana (2004), this species has a trans-Palaearctic distribution, but was previously unknown from Azerbaijan. The aedeagus of the above specimen is illustrated in Figs 182-183.

\section{Aleochara (Xenochara) kaszabi LıкоvsкÝ, 1968 (Figs 184-186)}

Aleochara (Polychara) kaszabi Lıкovskx́, 1968: $164 \mathrm{f}$.

\section{Type material examined:}

Holotype $\sigma^{\star}$ [dissected prior to present study; aedeagus flattened, somewhat deformed]: "Mongolia, Central aimak, 126 km Nv. Ulan-Baator, am Wege, Exp. Dr. Z. Kaszab, 1964 / Nr. 290, 9.VII.1964 / Holotypus 1966, Aleochara Kaszabi Likovsky [curator label] / Holotypus Aleochara ultima m., Zb. Likovský det. 1966 / Holotypus / Aleochara kaszabi Likovský, det. V. Assing 2009" (HNHM).

\section{Comment:}

This species has never been recorded since its original description, which is based on a single holotype male from "Mongolia: Central aimak, 126 km N von Ulan-Baator" (Likovsky 1968). An examination of the holotype revealed that the aedeagus is deformed (probably squeezed in the course of microscopic preparation). In external characters, the general morphology of the aedeagus, in particular the shape of the ventral process and the internal structures (Figs 184-186), A. kaszabi is highly similar to $A$. sanguinea and $A$. villosa Mannerheim, 1839 . It is separated from 
both species by the denser punctation of the elytra and the abdomen, as well as by the different shape of the apical internal structures of the aedeagus.

\section{Aleochara (Xenochara) pernigra SCHUBERT, 1906 (Figs 187-196)}

Aleochara pernigra SCHUBERT, 1906: 378.

Type material examined:

Lectotype + , present designation: "Kashmir. Songam. K. Rost. / Aleochara pernigra. Schubert II.1906. / Type / Hololectotypus Aleochara pernigra Schubert, Zb. Likovský det. 1965 / Lectotypus ㅇ Aleochara pernigra Schubert, desig. V. Assing 2009 / Aleochara pernigra Schubert, det. V. Assing 2009" (MNHUB). Paralectotype $\odot$ : same data, but "Paralectotypus" (MNHUB).

Additional material examined:

Mongolia: 1 ㅇ, 126 km N Ulan-Baator, 1100 m, 9.VII.1964, leg. Kaszab (HNHM).

Kyrgyzstan: 6 exs., Issyk-Kul, Terskej Alatau, Ottuk valley, 42¹6'N, 7903'E, 2900 m, 26.-27.VII.2005, leg. Schmidt (cAss).

China: 14 exs., Qinghai, Yunning Si [lamasery], $36^{\circ} 46^{\prime} \mathrm{N}, 102^{\circ} 11^{\prime} \mathrm{E}, 2890 \mathrm{~m}$, moist coniferous forest, baited pitfall traps (fish), 1.-16.VII.2005, leg. Hájek et al. (cSch, cAss).

\section{Comment:}

The original description is based on an unspecified number of syntypes from "Kashmir (Songam)" (SCHubert 1906). Two syntypes, both of them females, were located in the collections of the MNHUB. These specimens were studied by LikovskÝ (1965c), who attached lectotype labels to them, but never published the designation. The female in better condition is here designated as the lectotype; its spermatheca is illustrated in Fig. 196.

\section{Redescription:}

In external characters, this species much resembles species of the $A$. sparsa group, from which it is reliably separated only by the sexual characters:

$\sigma^{\top}$ : posterior margin of tergite VIII concave (Fig. 187); sternite VIII posteriorly distinctly produced in the middle (Fig. 188); median lobe of aedeagus as in Figs. 189-191.

$\rightarrow$ : posterior margin of tergite VIII weakly concave (Fig. 192), that of sternite VIII convex (Fig. 193); spermatheca as in Figs 194-196.

\section{Distribution:}

This species was previously known from Kashmir, Mongolia, and the Altai range in Siberia (Likovsкx́ 1971) and is here reported from Kyrgyzstan, the whole of Middle Asia, and China for the first time.

Aleochara (Xenochara) ultima LıкоvsкÝ, 1972 (Figs 197-198)

Aleochara (Polychara) ultima Likovskŕ, 1972: 164 f.

Type material examined:

Holotype $\sigma^{\star}$ [dissected prior to present study]: "Mongolia, Chovd aimak, Mongol Altaj Gebirge, cca $35 \mathrm{~km} \mathrm{~N}$ von Somon Uenč / Nr. 646, 8.VII.1966 / Holotypus 1970, Aleochara ultima Likovsky [curator label] / Holotypus Aleochara ultima m., det. Z. Likovský 1970 / Holotypus / Aleochara ultima Likovský, det. V. Assing 2009" (HNHM). 

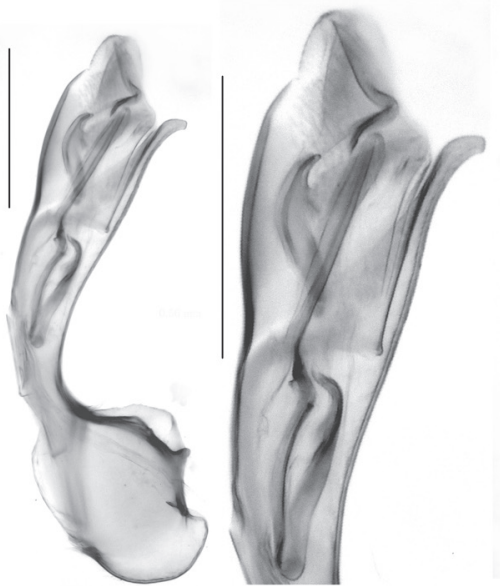

182

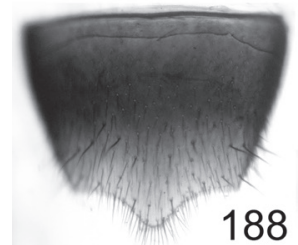

183
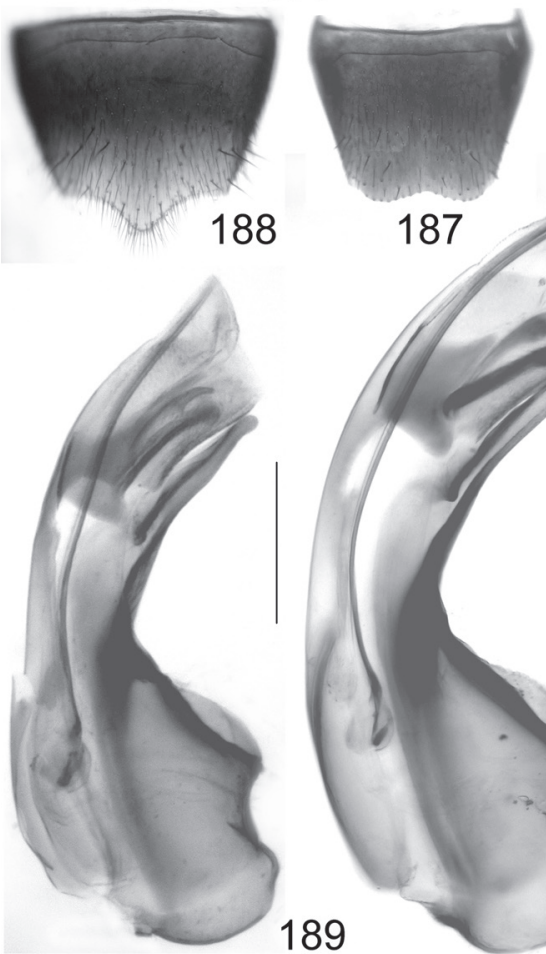

189
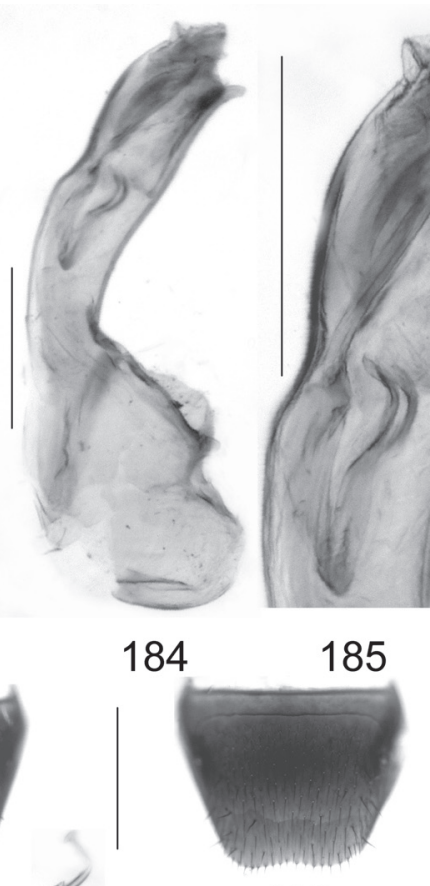

192

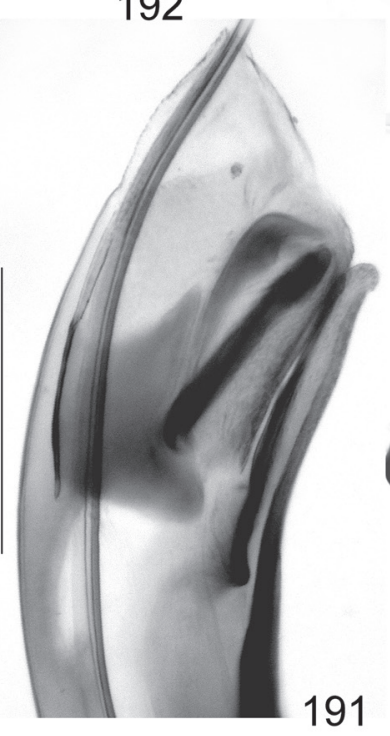

194

193

Figs 182-196: Aleochara sanguinea (Linnaeus) (182-183), A. kaszabi Likovskí (184-186; holotype), and A. pernigra Schubert (187-196; 196: lectotype; 187-189, 192-194: Kyrgyzstan; 190-191, 195: China): median lobe of aedeagus in lateral view $(182,184,189-190)$; apical portion of median lobe of aedeagus in lateral view $(183,185,191)$; apical internal structure of aedeagus (186); male tergite VIII (187); male sternite VIII (188); female tergite VIII (192); female sternite VIII (193); spermatheca (194-196). Scale bars: 187-188, 192-193: $0.5 \mathrm{~mm}$; 182-185, 189-191, 194-196: $0.2 \mathrm{~mm}$; 186: $0.1 \mathrm{~mm}$. 


\section{Comment:}

The original description is based on a single holotype male from "Chovd aimak: Mongol Altai Gebirge, cca 35 km N von Somon Uenč" (Likovsky 1972).

\section{Redescription:}

Body length $4.0 \mathrm{~mm}$. Coloration: head, pronotum, and abdomen blackish-brown, abdominal apex paler; elytra dark yellowish, with the anterior margin and the suture narrowly and diffusely infuscate; legs yellowish-brown; antennae dark-brown with antennomeres I-III yellowish-brown. Pronotum relatively small in relation to head, approximately 1.35 times as wide as long and 1.3 times as wide as head. Elytra approximately as long as pronotum. Metatarsus approximately 0.8 times as long as metatibia; metatarsomere I approximately as long as the combined length of II and III.

$\sigma^{\star}$ : posterior margin of tergite VIII broadly convex, in the middle weakly concave; sternite VIII posteriorly distinctly produced, in the middle almost acutely angled; median lobe of aedeagus as in Figs 197-198.

ㅇ: unknown.

\section{Comparative notes:}

Based on external characters and the morphology of the aedeagus, this species refers to the A. sparsa group. It is distinguished from other species of this group particularly by the coloration, the relatively small pronotum, the long elytra, and by the shape and internal structures of the aedeagus.

\section{Distribution:}

Only the holotype from Mongolia has become known.

\section{Aleochara (Xenochara) turkestanica LiKovsKÝ, 1966 (Figs 199-201)}

Aleochara (Polychara) turkestanica Liкоvsќ́ 1966: $1 \mathrm{ff}$.

Type material examined:

Holotype o: "Turkestan, Aulie Ata / Aulie / A. Banghaasi m. i. 1. / Aleochara haemoptera Kr., Coll. Reitter / Holotypus Aleochara turkestanica m., Zb. Likovský det. 66 / Holotypus / Aleochara turkestanica Likovský, det. V. Assing 2009" (HNHM). Paratype ㅇ: "Turkestan, Aulie Ata / Aleochara haemoptera Kr., Coll. Reitter / Allotypus Aleochara turkestanica m., Zb. Likovský det. 66 / Allotypus / Aleochara turkestanica Likovský, det. V. Assing 2009" (HNHM).

\section{Comment:}

The original description is based on two type specimens, a male holotype and a female paratype, both from "Turkestan, Aulie Ata" (Lıkovský 1966).

\section{Redescription:}

Body length 3.5-3.9 mm. Body conspicuously bicoloured: head, and abdomen blackish-brown, abdominal apex (segments IX-X, posterior margins of segments VII and VIII) pale yellowish; pronotum dark-brown; elytra pale yellowish, distinctly contrasting with the much darker head, pronotum, and abdomen; legs yellowish-brown to reddish-brown; antennae dark-brown. 
Antennae relatively massive. Palpomere III of maxillary palpus distinctly more than twice as long as wide. Head and pronotum with fine and moderately dense punctation; elytra with dense and rather shallow punctation. Pronotum approximately 1.30-1.35 times as wide as long and 1.4 times as wide as head. Elytra 0.80-0.85 times as long as pronotum. Abdomen with fine and moderately sparse punctation; anterior impressions of tergites III-V rather shallow and with sparse and very fine punctation.

$0^{\star}$ : median lobe of aedeagus as in Figs 199-200.

ㅇ: spermatheca as in Fig. 201.

\section{Comparative notes:}

Like the preceding species, $A$. turkestanica refers to the $A$. sparsa group. It is characterised particularly by the conspicuously bicoloured body, the relatively massive antennae, the fine and sparse punctation of the anterior impressions of tergites III-V, and by the primary sexual characters.

\section{Distribution:}

This species has become known only from the type locality in Kazakhstan.

\section{Aleochara (Xenochara) gobiensis Lıкоvsки́, 1968 (Fig. 202)}

Aleochara (Polychara) gobiensis Likovskŕ, 1968: 157 f.

\section{Type material examined:}

Holotype + [dissected prior to present study; spermatheca damaged]: "Mongolia: Chentev aimak, 20 km SW von Somon Batnorov, 1000 m, Exp. Dr. Z. Kaszab, 1965 / Nr. 458, 21.VIII.1965 / Holotypus 1966, Aleochara gobiensis Likovsky [curator label] / Holotypus Aleochara gobiensis m., Zb. Likovský det. 1966 / Holotypus / Aleochara gobiensis Likovský, det. V. Assing 2009" (HNHM).

\section{Comment:}

The original description is based on a single holotype female from "Mongolia: Chentej aimak, 20 km SW von Somon Batnorov" (Likovský 1968).

\section{Redescription:}

Highly similar to $A$. turkestanica, but distinguished as follows:

coloration similar to that of $A$. turkestanica, but apex of abdomen not distinctly paler than remainder of abdomen; palpomere III of maxillary palpus very short and apically strongly dilated, less than twice as long as wide (similar to that of $A$. sparsa), antennae less massive and shorter; forebody with well-defined, denser, and more distinct punctation; punctation of abdomen denser, coarser, and more defined; anterior impressions of tergites III-V dense and distinct.

$o^{\top}$ : unknown.

ㅇ: spermatheca as in Fig. 202.

\section{Distribution:}

This species has not been recorded since its original description and is currently known only from the type locality in Mongolia. 


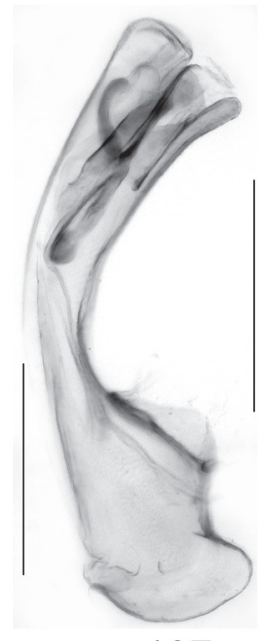

197
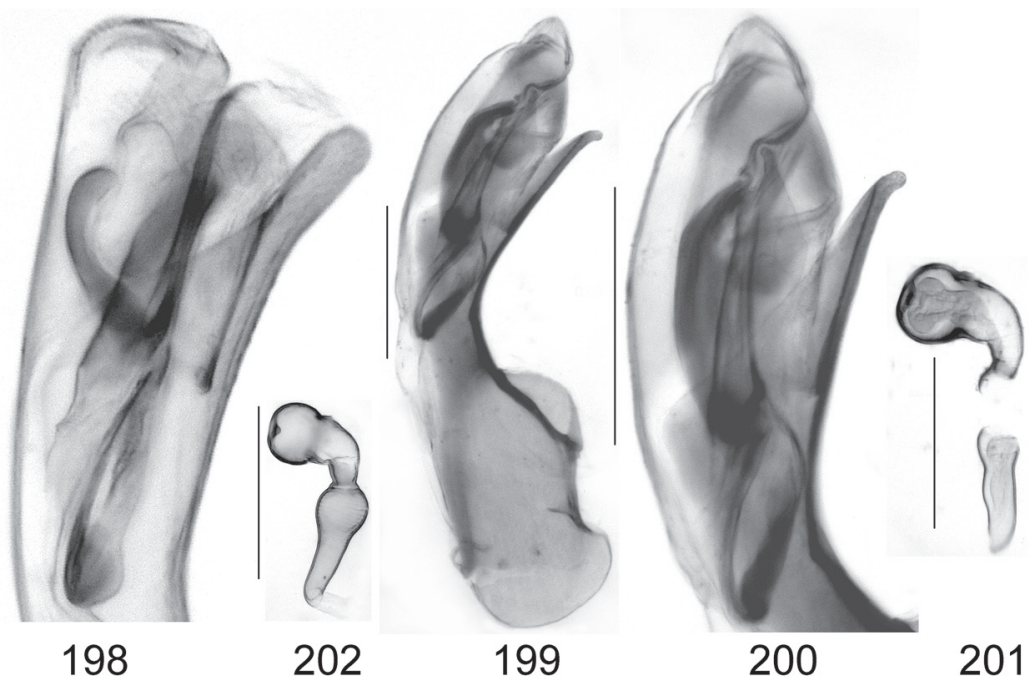

Figs 197-202: Aleochara ultima LıкоvsкÝ (197-198; holotype), A. turkestanica LiKovsкÝ (199-201; 199-200: holotype; 201: paratype), and A. gobiensis Likovskŕ (202; holotype): median lobe of aedeagus in lateral view $(197,199)$; apical portion of median lobe of aedeagus in lateral view $(198,200)$; spermatheca (201-202). Scale bars: 197, 199-202: $0.2 \mathrm{~mm}$; 198: $0.1 \mathrm{~mm}$.

Aleochara (Xenochara) himalayanae nov. sp. (Figs 203-210)

\section{Type material:}

Holotype $\sigma^{\top}$ : "China: Gansu province, Xiahe (=Labrang) env., 35¹1.5'N, 102³0.6'E, $2940 \mathrm{~m}$ (GPS), 19.-22.VI.2005, J. Hájek, D. Král \& J. Ružička leg. [CH 1] / individually collected, grasslands, close valley with loess loam near the stream, in burrows and on excrements of Marmota himalayana / Holotypus ơ Aleochara himalayanae sp. n., det. V. Assing 2009" (cAss). Paratypes: 3 exs.: same data as holotype (cSch, cAss); 1 ex.: "China: Gansu province, Sangke env., 3506.7'N, $102^{\circ} 25.1^{\prime} E, 3057$ m (GPS), 21.VI.2005, J. Hájek, D. Král \& J. Ružička leg. [CH 3] / individually collected, grasslands, on dog carrion and under stones near the stream; in cow and sheep excrements on pasture" (cSch); 8 exs.: "China: Qinghai province, Yunning Si [lamasery], 2890 m, 36²5.6'N, 102 10.6'E, (GPS), 1.-16.VII.2005, J. Hájek, D. Král \& J. Ružička leg. / [CH 10 \& 19]; baited pitfall traps (fish meat) with ethylene glycol; wet coniferous forest, close valley above the village" (cSch, cAss).

\section{Description:}

Body length: 3.8-6.0 mm. Habitus as in Fig. 203. Coloration: head, pronotum, and abdomen blackish, with the posterior margin of segment VIII reddish; elytra bright reddish, distinctly contrasting with remainder of body, anterior margin infuscate; legs dark reddish, with the femora usually slightly darker; antennae blackish, antennomeres I-III often slightly paler brown.

Head approximately as long as wide (Fig. 204); punctation relatively fine and moderately sparse; interstices on average distinctly wider than diameter of punctures and without microsculpture; eyes moderately convex, somewhat longer than postocular region in dorsal view. Antenna slender; antennomere IV approximately as long as wide or weakly transverse; V very weakly transverse, distinctly larger (longer and broader) than IV; VI-X weakly increasing in 
width; X approximately 1.5 times as wide as long; XI slightly longer than the combined length of IX and X (Fig. 205).

Pronotum 1.30-1.35 times as wide as long and approximately 1.45 times as wide as head, widest in or slightly behind the middle; posterior angles very obtuse, but marked (Fig. 204); punctation somewhat variable, rather dense and relatively fine; interstices on average approximately as wide as diameter of punctures, without microsculpture (except for some micropunctation).

Elytra approximately as long as pronotum (Fig. 204); posterior margin near posterior angles obliquely truncate, not sinuate; punctation coarser and denser than that of pronotum; interstices much narrower than diameter of punctures. Legs moderately long and slender; metatarsus 0.8 0.9 times as long as metatibia; metatarsomere I elongate, approximately as long as the combined length of II-IV.

Abdomen widest at segments IV/V; tergites III-V with moderately deep, very densely and rather coarsely punctate anterior impressions; punctation moderately coarse, much denser on anterior than on posterior tergites; interstices without microsculpture; posterior margin of tergite VIII weakly concave (Fig. 206).

$\mathrm{O}^{\mathrm{x}}$ : posterior margin sternite VIII strongly, almost acutely produced, in the middle with long and dense marginal setae; median lobe of aedeagus with distinct, strongly sclerotised pair of carinae between crista apicalis and base of ventral process (Figs 207-209).

ㅇ: posterior margin of sternite VIII weakly (very obtusely) angled in the middle and with much shorter marginal setae; spermatheca as in Fig. 210.

\section{Etymology:}

The name (Latin: noun, genitive) is derived from the specific epithet of the Himalayan marmot (Marmota himalayana), with which this species may be associated.

\section{Comparative notes:}

Based on the morphology of the primary and secondary sexual characters, $A$. himalayanae is closely related to A. marmotae Sainte-Claire Deville, 1927 from the Alps. It is distinguished from this species by numerous external characters alone, particularly by the conspicuously bicoloured body (A. marmotae: elytra usually as dark as head and pronotum, more rarely dark-brown), the very sparse micropunctation and glossy appearance of the forebody $(A$. marmotae: head and pronotum with very dense micropunctation and almost matt), the much more slender antennae, the more defined punctation of the head and pronotum, the much denser and coarser punctation of the abdomen, and the relatively longer metatarsomere I. The median lobe of the aedeagus is distinctly smaller than in $A$. marmotae, has a weakly sinuate ventral process (lateral view), a smaller crista apicalis and internal structures of different shape; for an illustration of the aedeagus and the spermatheca of $A$. marmotae see Figs 211-212.

\section{Distribution and bionomics:}

The species is known from three localities in Gansu and Qinghai provinces, China. The type specimens were collected from burrows and dung of Marmota himalayana and with fish-baited pitfall traps at altitudes of 2890-3060 m. The circumstances of collection and the observation that the sexual characters suggest a close relationship to $A$. marmotae suggest that $A$. himalayanae may be associated with the Himalayan marmot. 

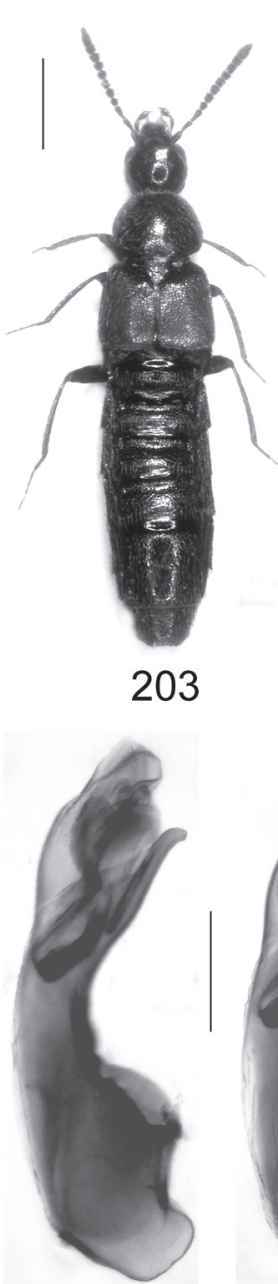

207

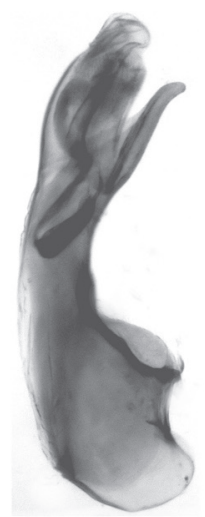

208

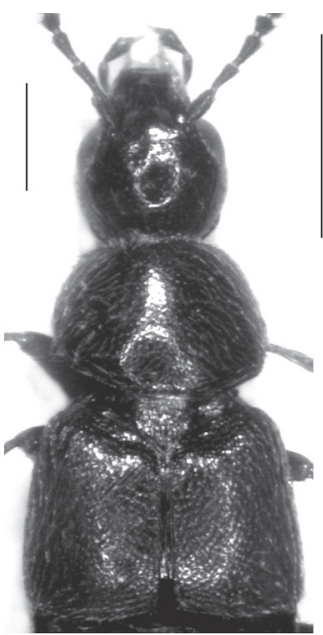

204
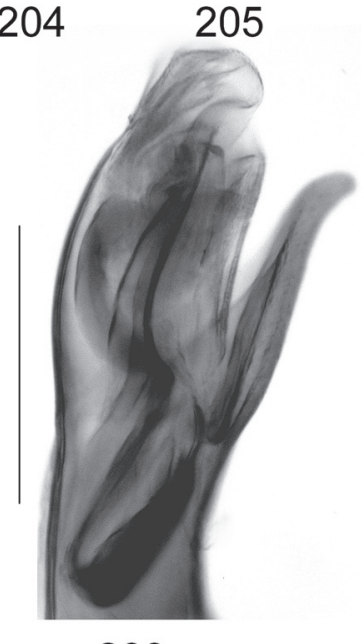

209

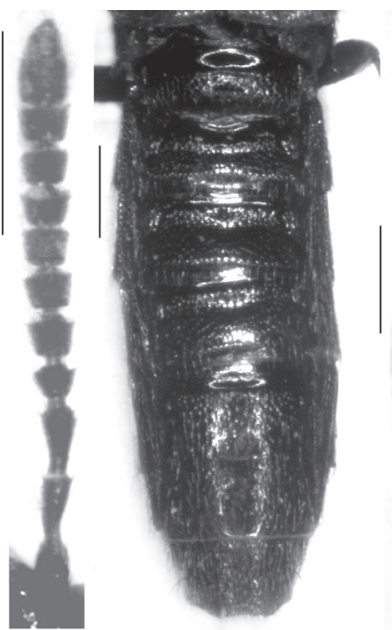

206
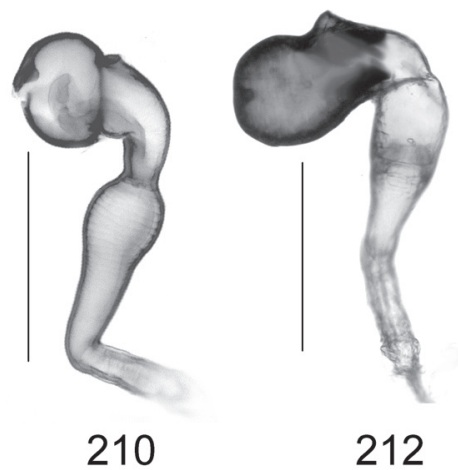

212

Figs 203-212: Aleochara himalayanae sp. n. (203-210) and A. marmotae SAinte-Claire Deville (211-212): habitus (203); forebody (204); antenna (205); abdomen (206); median lobe of aedeagus in lateral view (207-208, 211); apical portion of median lobe of aedeagus in lateral view (209); spermatheca $(210,212)$. Scale bars: 203: $1.0 \mathrm{~mm}$; 204-206: $0.5 \mathrm{~mm}$; 207-212: $0.2 \mathrm{~mm}$.

Aleochara (Xenochara) digitulata nov. sp. (Figs 213-222)

Type material:

Holotype ơ: "China: Gansu province, Xiahe (=Labrang) env., 35¹1.5'N, 102 30.6'E, $2940 \mathrm{~m}$ (GPS), 19.-22.VI.2005, J. Hájek, D. Král \& J. Ružička leg. [CH 1] / individually collected, grasslands, close valley with loess loam near the stream, in burrows and on excrements of Marmota himalayana / Holotypus o Aleochara digitulata sp. n., det. V. Assing 2009" (cAss). Paratypes: 5 exs.: same data as holotype (cSch, cAss); 1 ex.: "China: Gansu province, Sangke env., 3506.7'N, 
102²5.1'E, 3057 m (GPS), 21.VI.2005, J. Hájek, D. Král \& J. Ružička leg. [CH 3] / individually collected, grasslands, on dog carrion and under stones near the stream; in cow and sheep excrements on pasture" (cSch).

\section{Description:}

Body length: 3.8-6.1 mm. Habitus as in Fig. 213. Coloration: whole body, including antennae, blackish; legs dark-brown to blackish-brown.

Head approximately 1.1 times as long as wide (Fig. 214); punctation relatively coarse and moderately dense; interstices on average only slightly wider than diameter of punctures and without microsculpture; eyes moderately convex, slightly longer than postocular region in dorsal view. Antenna moderately slender; antennomere IV approximately as long as wide or weakly transverse; $\mathrm{V}$ distinctly broader than IV; V-X of similar shape, very weakly increasing in width, $\mathrm{X}$ only slightly broader than V; X approximately 1.5 times as wide as long; XI approximately as long as the combined length of IX and X (Fig. 215).

Pronotum 1.25 times as wide as long and approximately 1.45-1.60 times as wide as head, widest in or slightly behind the middle; posterior angles broadly rounded, very weakly marked (Fig. 214); punctation similar to that of head, but slightly denser; interstices on average approximately as wide as diameter of punctures or slightly narrower, without microsculpture.

Elytra approximately 0.85 times as long as pronotum; posterior margin near posterior angles obliquely truncate, not sinuate (Fig. 214); punctation coarse and conspicuously dense; interstices much narrower than diameter of punctures, without microsculpture. Legs moderately long and slender; metatarsus 0.8-0.9 times as long as metatibia; metatarsomere I elongate, longer than the combined length of II and III, but shorter than the combined length of II-IV.

Abdomen with segments III-VI of subequal width; tergites III-V with moderately deep, densely and distinctly punctate anterior impressions, punctures similar to those of pronotum or somewhat coarser; punctation of remainder of dorsal surface distinct, much denser on anterior than on posterior tergites; interstices without microsculpture; posterior margin of tergite VIII weakly concave (Fig. 216).

$\sigma^{\star}$ : posterior margin sternite VIII distinctly produced, apex forming a right angle; median lobe of aedeagus as in Figs 217-218.

+ : posterior margin of sternite VIII broadly convex; spermatheca as in Fig. 219.

\section{Etymology:}

The name (Latin: adjective) is derived from the diminutive digitulus (small finger) and refers to the shape of the apical internal structures of the aedeagus.

\section{Comparative notes:}

Based on the morphology of the primary and secondary sexual characters, $A$. digitulata refers to the $A$. sparsa group. Among the species of this group, the new species is characterised particularly by the relatively slender head (in relation to the pronotum), the densely punctate elytra, and the shape and the internal structures of the median lobe of the aedeagus. The morphology of the aedeagus and the shape of the spermatheca are somewhat similar to those of $A$. villosa Mannerheim, 1830, A. sanguinea, and $A$. kaszabi. The internal structures of the aedeagus are most similar to those of $A$. kaszabi, from which $A$. digitulata is distinguished by the much more distinct and denser punctation of the forebody, the glossy appearance (interstices without apparent microsculpture), and the different shape of the median lobe of the aedeagus. For illustrations of the male primary sexual characters of $A$. kaszabi see Figs 184-186. 


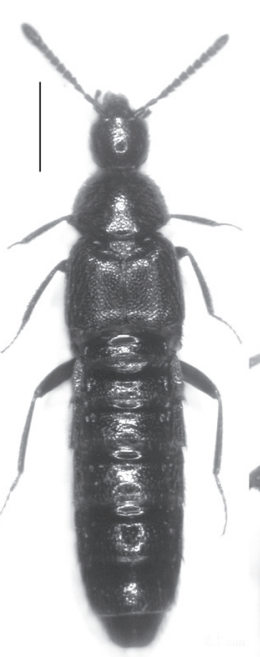

213
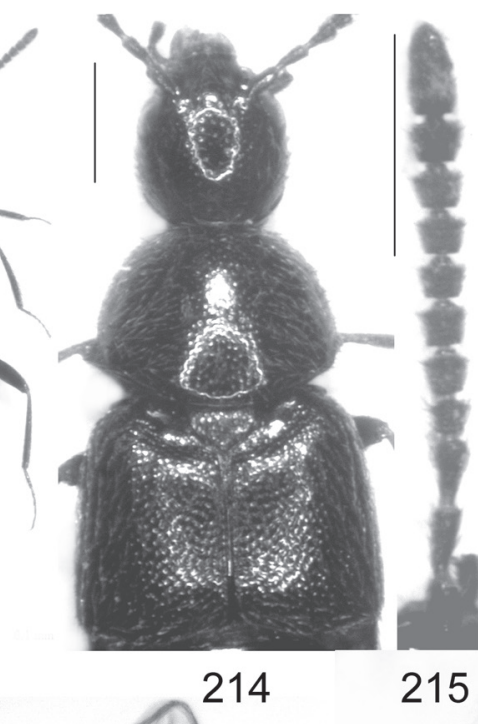
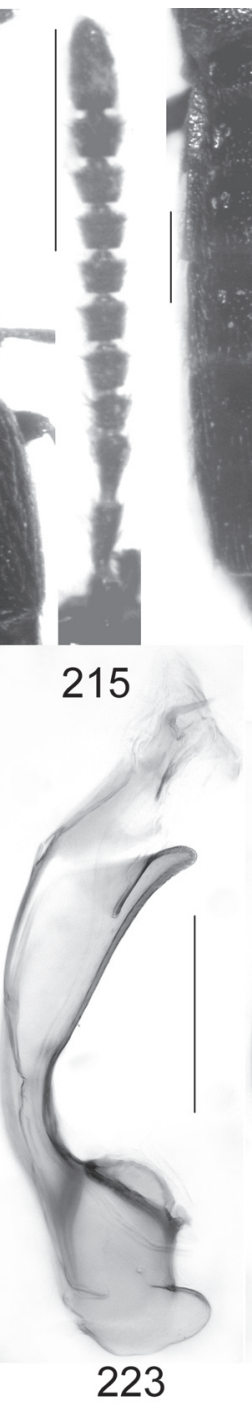

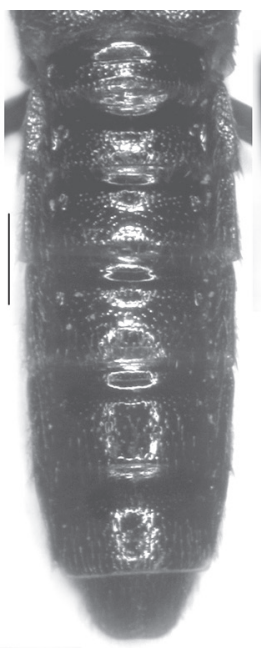

216

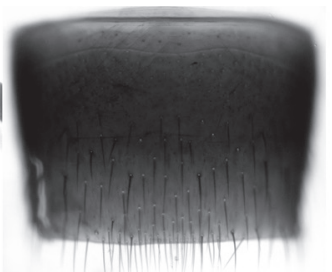

221
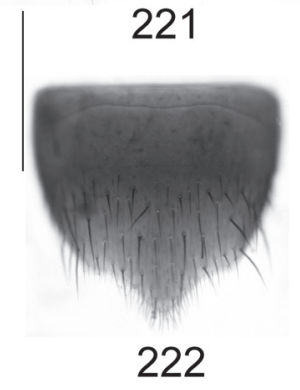

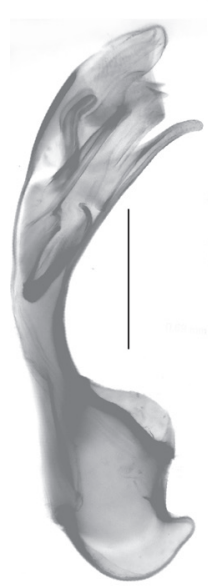

217

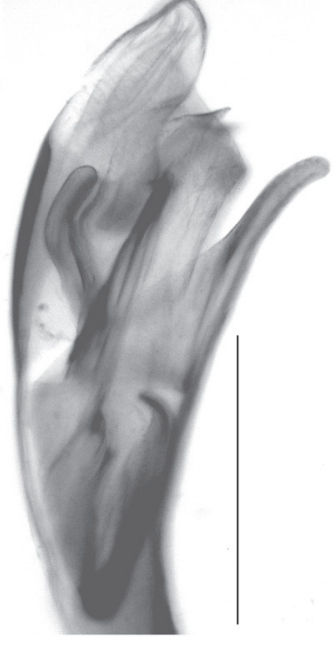

218
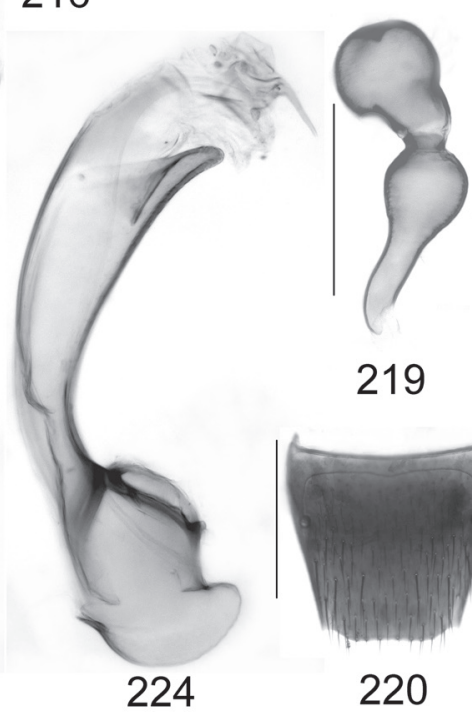

219

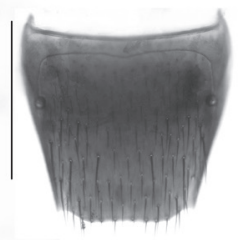

220

Figs 213-224: Aleochara digitulata sp. n. (213-219) and A. leptocera Eppelsheim (220-224): habitus (213); forebody (214); antenna (215); abdomen (216); median lobe of aedeagus in lateral view (217, 223-224); apical portion of median lobe of aedeagus in lateral view (218); spermatheca (219), male tergite VIII (220); male sternite VII (221); male sternite VIII (222). Scale bars: 213: $1.0 \mathrm{~mm}$; 214-216, 220-222: $0.5 \mathrm{~mm}$; 217-219, 223-224: $0.2 \mathrm{~mm}$.

\section{Distribution and bionomics:}

The species is known only from two localities in Gansu and Qinghai provinces, China. With one exception, all the type specimens were collected from burrows and dung of Marmota himalayana at an altitude of approximately $3000 \mathrm{~m}$. 
Aleochara (Rheochara) leptocera EPPELSHEIM, 1889 (Figs 220-224)

Aleochara (Baryodma) leptocera Eppelsheim, 1889: $167 \mathrm{f}$.

Type material examined:

Neotype 오 : ㅇ / El Ramleh, Nest von Spalax Ehrenbergi / Palästina, Israel / leptocera Epp / ex coll. Scheerpeltz / Neotypus Rheochara leptocera Epp. / Aleochara leptocera Eppelsheim det. V. Assing 2007" (NHMW).

Additional material examined:

Turkey: 2 o $^{\star}$, Kahramanmaraş, Nurhak/Elbistan, 2200-2500 m, VI.1967, leg. Schubert (NHMW, cAss).

Iran: $10^{\prime}$, Esfahan, S Fereydun Shahr, Gukan, $32^{\circ} 43^{\prime} \mathrm{N}, 50^{\circ} 05^{\prime} \mathrm{E}, 2260,2 . V I I .2004$, leg. Frisch (MNHUB).

\section{Comment:}

The neotype was already examined, figured, and its status discussed by Assing (2007a). According to Smetana (2004), the species has been reported from Israel, Lebanon, Syria, and Turkey, but confirmed records other than from the type locality were unknown. The additional specimens above represent the first record from Iran and the first records with specified localities from Turkey. The previously unknown male primary and secondary sexual characters are illustrated in Figs 220-224. The two specimens from Turkey differ from the neotype and the male from Iran by a relatively slightly smaller head and slightly longer elytra, but the aedeagus is identical.

Aleochara (Rheochara) arachnipes FAUVEL, 1900 (Figs 225-228)

Aleochara arachnipes FAUveL, 1900: $248 \mathrm{f}$.

Type material examined:

Holotype $o^{\top}$ [slightly teneral; dissected prior to present study; aedeogus missing]: "831 / Fl. Tschu / J. Sahlb. / arachnipes Fvl. / Type / Coll. R. I. Sc. N. B. / Holotypus o Aleochara arachnipes Fauvel, rev. V. Assing 2009 / Aleochara arachnipes Fauvel, det. V. Assing 2009" (IRSNB).

\section{Comment:}

The original description is based on a single specimen from "Turkestan: Ala-Tau" (FAuvel 1900). The species is similar to $A$. spadicea (ERICHSON 1837), but distinguished by more slender body (Fig. 225), longer antennae with distinctly more slender antennomeres (Fig. 227), a much less transverse and less convex pronotum (Fig. 226), distinctly longer and especially more slender legs (metarsus approximately 1.2 times as long as metatibia; metatarsomere I approximately as long as the combined length of II and III), and shallower anterior impressions of abdominal tergites III-V (Fig. 228).

So far, only the holotype of this species has become known. 


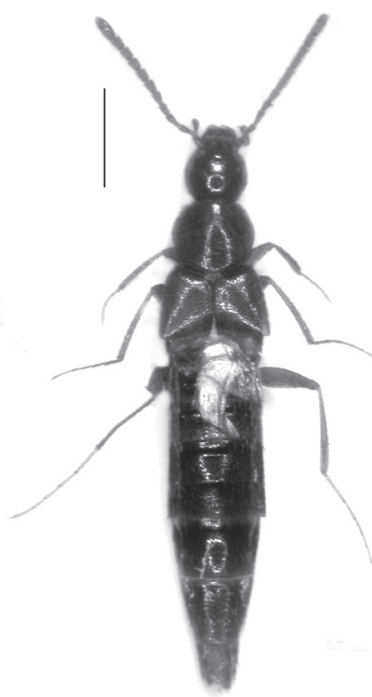

225

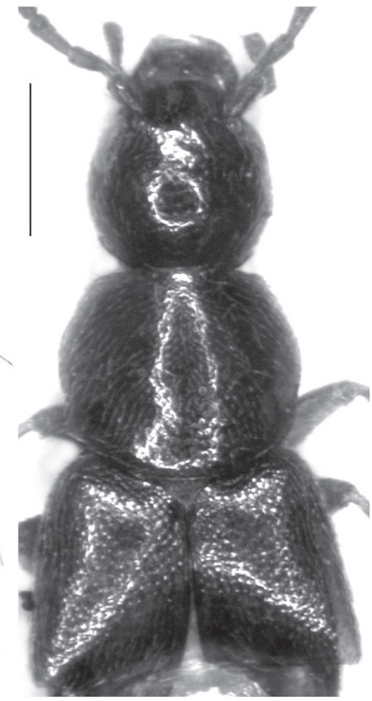

226

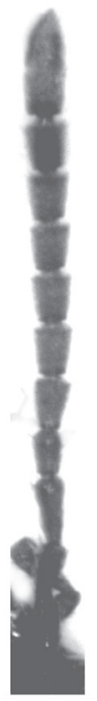

227

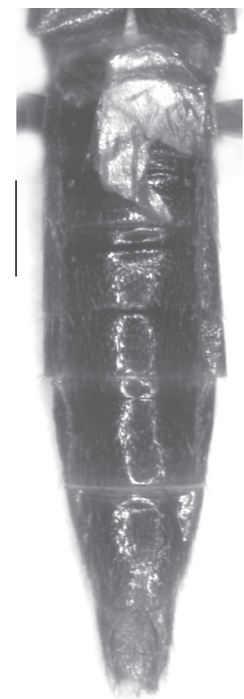

228

Figs 225-228: Aleochara arachnipes Fauvel, holotype: habitus (225); forebody (226); antenna (227); abdomen (228). Scale bars: 225: $1.0 \mathrm{~mm}$; 226-228: $0.5 \mathrm{~mm}$.

\section{Acknowledgements}

I am indebted to the colleagues indicated in the material section for the loan of material from collections under their care. In particular, I am grateful to Michael Schülke and Andrej Gontarenko for the generous gift of the holotypes of several species described in this paper. Benedikt Feldmann and Marc Tronquet kindly communicated additional records of $A$. maculata, A. maculipennis, and A. tenuicornis; the correct interpretation of both species was verified via an exchange of photos of the genitalia. Benedikt Feldmann also proofread the manuscript.

\section{References}

ÁDÁM, L. 2008: New synonymies and new combinations in European Aleocharinae (Coleoptera: Staphylinidae). - Travaux du Muséum National d'Histoire Naturelle "Grigore Antipa" 51: 137-151.

Assing, V. 1995: The Palaearctic species of Emplenota Casey, Polystomota Casey, Triochara Bernhauer and Skenochara Bernhauer \& SCHeErpeltz, with descriptions of three new species (Coleoptera, Staphylinidae, Aleocharinae). - Beiträge zur Entomologie, Berlin 45: 217-237.

Assing, V. 2007a: On the Aleocharini of Turkey, with notes on some species from adjacent regions (Coleoptera: Staphylinidae, Aleocharinae). - Beiträge zur Entomologie, Keltern 57: 177-209.

Assing, V. 2007b: New species and additional records of Staphylinidae from Turkey V (Coleoptera). Stuttgarter Beiträge zur Naturkunde Serie A (Biologie) 700: 1-64.

Assing, V. \& SchüLKE, M. 2001: Supplemente zur mitteleuropäischen Staphylinidenfauna (Coleoptera: Staphylinidae). II. - Entomologische Blätter 97: 121-176.

Baranowski, R. 1977: Intressanta skalbaggsfynd 2 (Coleoptera). - Entomologisk Tidskrift 98: 133-140.

BARANOWSKI, R. 1979: Skalbaggar som lever i kaningångar. - Entomologisk Tidskrift 100: 57-60.

Beare, T. H. \& Evans, W. 1909: Coleoptera from moles' nests in the south-east of Scotland. - The Annals of Scottish Natural History 1909: 86-91.

BeIer, W. \& Korge, H. 2001: Biodiversität der Wirbellosenfauna im Gebiet des ehemaligen GUS-Truppenübungsplatzes Döberitz bei Potsdam (Land Brandenburg). Teil I: Käfer (Insecta, Coleoptera). - Märkische Entomologische Nachrichten, Sonderheft 1: 1-150. 
Bernhauer, M. 1901: Die Staphyliniden der paläarktischen Fauna. - Verhandlungen der kaiserlich-königlichen zoologisch-botanischen Gesellschaft in Wien 51: 430-506.

Bernhauer, M. 1936a: Aus der Praxis des Käfersammlers. XXX. Ueber den Fang von Staphyliniden in Ziesellöchern und im Ufersand. Mit der Beschreibung einer neuen ziesellochbewohnenden Oxytelus-Art. - Koleopterologische Rundschau 22: 181-186.

Bernhauer, M. 1936b: Neuheiten der paläarktischen Staphylinidenfauna III. - Koleopterologische Rundschau 22: 50-58.

Bernhauer, M. 1940: Neuheiten der paläarktischen Staphylinidenfauna (Col. Staph.). - Mitteilungen der Münchener Entomologischen Gesellschaft 30: 1025-1047.

BickHARDT, H. 1907: Käfer in Nestern. - Entomologische Blätter 3: 1-11.

Brisout de Barneville, C. 1863: [new taxa]. - In: Grenier, A.: Catalogue des coléoptères de France par M. le Dr. A Grenier et matériaux pour servir à la faune des coléoptères français. - Paris, A. Grenier: iv + 3-79, 1-135.

Eppelsheim, E. 1889: Neue Staphylinen Europa's und der angrenzenden Länder. - Deutsche Entomologische Zeitschrift 33: 161-183.

Erichson, W. F. 1837: Die Käfer der Mark Brandenburg. Erster Band, Erste Abtheilung. - Berlin, F. H. Morin: viii +384 pp.

Fauvel, A. 1886: Les Staphylinides du Nord d'Afrique. - Revue d'Entomologie 5: 9-100.

FAUvel, A. 1900: Staphylinides paléarctiques nouveaux. - Revue d'Entomologie 19: 218-253.

Fauvel, A. 1902: Catalogue des staphylinides de la Barbarie, de la Basse-Égypte et des Îles Açores, Madères, Salvages et Canaries. - Revue d'Entomologie 21: 45-189.

Franz, H. 1938: Aus der Praxis des Käfersammlers. XXXIII. Eine Käferfauna aus Fuchsbauen des nördlichen Burgenlandes. - Koleopterologische Rundschau 24: 3032.

Ganglbauer, L. 1897: Einige neue Coleopteren des mitteleuropäischen Faunengebietes. - Verhandlungen der kaiserlich-königlichen zoologisch-botanischen Gesellschaft in Wien 47: 565-573.

Gensicke, F. 1960: Zur Kenntnis der Nestfauna einiger Muridenarten in der Umgebung von Greifswald. - Wissenschaftliche Zeitschrift der Ernst-Moritz-Arndt-Universität Greifswald 9: 189-197.

Gridelli, E. 1924: Resultati scientifici della spedizione Ravasini-Lona in Albania VII. - Staphylinidae. - Bollettino della Società Entomologica Italiana 56: 38-41.

Gyllenhal, F. 1810: Insecta Svecica descripta. Classis I. Coleoptera sive Eleuterata. Tomi I. Pars II. - Scaris, L. J. Leverentz: xix +660 pp.

Hansen, M.; Mahler, V.; Pritzl, G. \& Runge, J. B. 1994: 13. tillæg til 'Fortegnelse over Danmarks biller' (Coleoptera). - Entomologiske Meddelelser 62: 65-89.

Havelka, J. 1964: Príspěvek k poznání slovenska, 1. Část. - Acta Rerum Naturalium Musei Nationalis Slovaci 10: 66-123.

Horion, A. 1967: Faunistik der mitteleuropäischen Käfer. Bd. XI: Staphylinidae, 3. Teil: Habrocerinae bis Aleocharinae (ohne Subtribus Athetae). - Überlingen-Bodensee: 419 pp.

Jászay, T. \& Majzlan, O. 2004: Interesting findings of six rove beetles from Slovakia (Coleoptera: Staphylinidae). - Acta Rerum Naturalium Musei Nationalis Slovaci 50: 55-58.

Joy, N. H. 1932: A practical handbook of British beetles. Vol. I. - London: 622 pp.

Klimaszewski, J. 1984: A revision of the genus Aleochara Gravenhorst of America north of Mexico (Coleoptera: Staphylinidae, Aleocharinae). - Memoirs of the Entomological Society of Canada 129: $1-211$.

Косн, K. 1968: Käferfauna der Rheinprovinz. - Decheniana (Bonn), Beiheft 13: 1-382.

KöHLER, F. 2000: Erster Nachtrag zum "Verzeichnis der Käfer Deutschlands". - Entomologische Nachrichten und Berichte 44: 40-84.

Köhler, F. \& Klausnitzer, B. 1998: Verzeichnis der Käfer Deutschlands. - Entomologische Nachrichten und Berichte, Beiheft 4: 1-185.

KraAtZ, G. 1856: Naturgeschichte der Insecten Deutschlands. Erste Abtheilung. Zweiter Band. Lieferung 1 und 2. - Berlin, Nicolai: viii + 376 pp.

KraAtZ, G. 1858: [new taxa]. - Bulletin de la Société entomologique de France 1858: clxxxviii-cxcii. 
KrásA, T. 1933: Nový druh "Aleochar" z hnizd švisté stepniho. (Acrtomys bobac Schreb.), Aleochara, subg. Rheochara Muls. Rey bobaci n. sp. - Časopis Ceskoslovenské Splečnosti Entomologické 30: 134-135.

Likovskx́, Z. 1965a: Ceskoslovenské druhy rodu Aleochara Gravenhorst (Coleoptera, Staphylinidae). - Acta Rerum Naturalium Musei Nationalis Slovaci 11: 29-53.

Liкоvsкx́, Z. 1965b: Aleochara-Arten. Ergebnisse der zoologischen Forschungen von Dr. Z. Kaszab in der Mongolei (Coleoptera, Staphylinidae). - Reichenbachia 7 (1965-1966): 47-55.

Likovskx́, Z. 1965c: Aleochara sparsa Heer - eine Mischart (Coleoptera, Staphylinidae). - Annotationes zoologicae et botanicae 22: 1-7.

Likovskx́, Z. 1966: Aleochara (Polychara) turkestanica sp. n. (Coleoptera, Staphylinidae). - Annotationes zoologicae et botanicae 35: 1-3.

Lıкоvsкx́, Z. 1968: 148. Aleochara-Arten II. Ergebnisse der zoologischen Forschungen von Dr. Z. Kaszab in der Mongolei (Coleoptera, Staphylinidae). - Reichenbachia 11: 153-164.

Lıкоvsкx́, Z. 1971: Einige west- und mittelasiatische Aleochara-Arten (Coleoptera, Staphylinidae). - Acta faunistica entomologica Musei Nationalis Pragae 14: 93-100.

LiкovsкÝ, Z. 1972: Ergebnisse der zoologischen Forschungen von Dr. Z. Kaszab in der Mongolei. 279. Aleochara-Arten III. (Coleoptera, Staphylinidae). - Annales historico-naturales Musei Nationalis Hungariae 64: 161-169.

Likovskx́, Z. 1973: Bemerkungen über die Gattung Aleochara Gravenhorst (Coleoptera, Staphylinidae). - Annotationes zoologicae et botanicae 71: 1-8.

Likovskx́, Z. 1974: Gattung Aleochara. - In: Freude, H.; Harde, K. W. \& Lohse, G. A. (eds.): Die Käfer Mitteleuropas, Band 5. - Krefeld, Goecke \& Evers: 293-304.

LiкоvsкÝ, Z. 1981: Ergebnisse der tschechoslovakisch-iranischen entomologischen Expeditionen nach dem Iran. Coleoptera: Staphylinidae, Subtribus Aleocharae. - Acta Entomologica Musei Nationalis Pragae 40: 359-370.

Likovskx́, Z. 1984: Über die Nomenklatur der Aleocharinen (Coleoptera, Staphylinidae). - Annotationes zoologicae et botanicae 160: 1-8.

Linke, M. 1907: Verzeichnis der in der Umgebung von Leipzig beobachteten Staphyliniden. - Sitzungsberichte der Naturforschenden Gesellschaft zu Leipzig 1906-1907: 1-54.

Lohse, G. A. 1961: Neuheiten der deutschen Käferfauna VIII. - Entomologische Blätter 57: 180-191.

Lohse, G. A. 1967: Die Aleocharini (s. lat.) des Niederelbegebietes und Schleswig-Holsteins (Col. Staphylinidae). - Verhandlungen des Vereins für Naturwissenschaftliche Heimatforschung Hamburg 36: 39-50.

Maus, C. 1998: Taxonomical contributions to the subgenus Coprochara Mulsant \& Rey, 1874 of the genus Aleochara Gravenhorst, 1802 (Coleoptera: Staphylinidae). - Koleopterologische Rundschau 68: 81-100.

Maus, C. 1999: Four new species of the genus Aleochara Gravenhorst, 1802, subgenus Coprochara Mulsant \& Rey, 1874 (Coleoptera: Staphylinidae). - Beiträge zur Entomologie, Berlin 49: 357-367.

Maus, C.; Mittmann, B. \& Peschke, K. 1998: Host records of parasitoid Aleochara Gravenhorst species (Coleoptera, Staphylinidae) attacking puparia of cyclorrhapheous Diptera. - Mitteilungen aus dem Museum für Naturkunde zu Berlin, Deutsche entomologische Zeitschrift 45: 231-254.

Mulsant, E. \& Rey, C. 1853: Description de quelques coléoptères nouveaux ou peu connus de la tribu des Brachélytres. - Opuscules entomologiques 2: 35-85.

Mulsant, E. \& Rey, C. 1874: Histoire naturelle des coléoptères de France. Brévipennes. Aléochariens. (Suite). - Aléocharaires. - Paris, Deyrolle: 1-162.

Nikitsky, N. B.; Semenov, V. B. \& Dolgin, M. M. 1998: Zhestkokrylye-ksilobionty, micetobionty l plastinchatousye Prioksko-Terrasnogo biosfernogo zapovednika (s obzorom fauny etikh grupp Moskovskoy oblasti). Dopolnenie l (s zamechanyami po nomenklature i sistematike nekotorykh zhukov Melandryidae mirovoy fauny). - Sbornik Trudov Zoologicheskogo Muzeya MGU (Supplement 1) 36: 1-60. 
Nikitsky, N. B. \& Semenov V. B. 2001: To the knowledge of the beetles (Coleoptera) of the Moscow Region [translation of Russian title]. - Bulletin of Moscow Society of Naturalists, Biological Series 106: 38-49.

Normand, H. 1934: Contribution au Catalogue des Coléoptères de Tunisie (4. fascicule). - Bulletin de la Société d'Histoire Naturelle de l'Afrique du Nord 25: 356-390.

Özkurt, Ş. Ö.; Sözen, M.; YIĞIt, N.; Kandemir, I.; ÇolaK, R.; Gharkheloo, M. M. \& ÇolaK, E. 2007: Taxonomic status of the genus Spermophilus (Mammalia: Rodentia) in Turkey and Iran with description of a new species. - Zootaxa 1529: 1-15.

Palm, T. 1972: Skalbaggar. Coleoptera, Kortvingar: Fam. Staphylinidae, Underfam. Aleocharinae (Aleuonota - Tinotus), Häfte 7, pp. 301-467. - In: Entomologiska Föreningen I Stockholm (ed.): Svensk Insektfauna 9, Stockholm.

Reitter, E. 1909: Fauna Germanica. Die Käfer des Deutschen Reiches. II. Band. - Stuttgart: 392 pp.

SAHLBERG, J. 1876: Enumeratio coleopterorum brachelytrorum Fenniae. I. Staphylinidae - Acta Societatis pro Fauna et Flora Fennica 1: 1-248.

Schubert, K. 1906: Einige neue paläarktische Staphyliniden aus Kashmir. - Deutsche Entomologische Zeitschrift 1906: 378-383.

Semenov, V. B. 1998: Aleochara tertiaria V. Semenov sp. n.; pp. 15-19. - In: Nikitsky, N. B.; Semenov, V. B. \& Dolgin, M. M.: Zhestkokrylye-ksilobionty, micetobionty 1 plastinchatousye PriokskoTerrasnogo biosfernogo zapovednika (s obzorom fauny etikh grupp Moskovskoy oblasti). Dopolnenie 1 (s zamechanyami po nomenklature i sistematike nekotorykh zhukov Melandryidae mirovoy fauny). - Sbornik Trudov Zoologicheskogo Muzeya MGU (Supplement 1) 36: 1-60.

Semenov, V. B. 2003: To the taxonomy of some species Aleocharinae (Coleoptera, Staphylinidae) collected in Moscow area and adjacent areas [translation of Russian title]. - Byulleten' Moskovskogo Obshchestva Ispytatelei Prirody Otdel Biologicheskii 108: 81-85.

Smetana, A. 2004: Staphylinidae, subfamily Aleocharinae, pp. 353-494. - In: Löbl, I. \& Smetana, A. (eds.): Catalogue of Palaearctic Coleoptera. II. Hydrophiloidea - Histeroidea - Staphylinoidea. - Stenstrup, Apollo Books: 942 pp.

Stan, M. \& Chimişliu, C. 2005: Rove beetles (Coleoptera: Staphylinidae) from the collection of the Oltenia Museum Craiova. - Entomologica romanica 10: 93-97.

Staniec, B. 1992: Aleochara breiti Ganglbauer, 1897 (Coleoptera, Staphylinidae) - novy dla fauny Polski przedstawiciel kusakowatych. - Wiadomości Entomologiczne 11: 149-153.

Tronquet, M. 2006: Catalogue iconographique des coléoptères des Pyrénées-Orientales. Volume I (édition revue et augmentée). Staphylinidae. - Revue de l'Association Roussillonnaise d'Entomologie 15 (Supplément): 1-127 + 78 plates.

Wagner, H. 1949: Beschreibung einer neuen deutschen Aleochara aus Hamsterbauten und kritische Bemerkungen zur Gattung. - Koleopterologische Zeitschrift 1: 15-31.

Weber, H. H. 1942: Über Funde von Phyllodrepa melis V. Hansen und Aleochara cuniculorum KR. in Dachsbauen Schleswig-Holsteins. - Entomologische Blätter 38: 125-127.

Welch, R. C. 1997: The British species of the genus Aleochara Gravenhorst (Staphylinidae). - The Coleopterist 6 (1): 1-48.

\section{Author's address:}

Dr. VolKer Assing

Gabelsbergerstr. 2

30163 Hannover

Germany

e-mail: vassing.hann@t-online.de

\section{Subject editor:}

B. Feldmann 